LORENA SALES DOS SANTOS

CRESCER NAS MARGENS:

DIÁSPORA, MIGRAÇÃO E MOVIMENTO NAS OBRAS DE CONCEIÇÃO EVARISTO, EDWIDGE DANTICAT E JAMAICA KINCAID 


\section{LORENA SALES DOS SANTOS}

\section{CRESCER NAS MARGENS: DIÁSPORA, MIGRAÇÃO E MOVIMENTO NAS OBRAS DE CONCEIÇÃO EVARISTO, EDWIDGE DANTICAT E JAMAICA KINCAID}

Texto submetido ao Programa de Pós-Graduação em Literatura, Curso de Doutorado do Departamento de Teoria Literária e Literaturas do Instituto de Letras da Universidade de Brasília - TEL-UnB, como um dos requisitos para a obtenção do título de Doutora em Literatura.

Orientadora: Profa. Dra. Cíntia Schwantes - UnB

Coorientadora: Darlene Sadlier - Indiana University 


\title{
CRESCER NAS MARGENS: DIÁSPORA, MIGRAÇÃO E MOVIMENTO NAS OBRAS DE CONCEIÇÃO EVARISTO, EDWIDGE DANTICAT E JAMAICA KINCAID
}

\author{
Texto submetido ao Programa \\ de Pós Graduação, Curso de \\ Doutorado do Departamento de Teoria \\ Literária e Literaturas do Instituto de \\ Letras da Universidade de Brasília - \\ TEL-UnB, como um dos requisitos para \\ a obtenção do título de Doutora em \\ Literatura. \\ Orientadora: Profa. Dra. Cíntia \\ Schwantes - UnB \\ Coorientadora: Profa. Dra. \\ Darlene Sadlier - Indiana University
}

Aprovado por:

\begin{tabular}{c}
\hline $\begin{array}{c}\text { Profa. Dra. Cíntia Schwantes (TEL-UnB) - Orientadora } \\
\text { Presidente da Banca }\end{array}$ \\
\hline Profa. Dra. Edileuza Penha de Souza (Decanato de Extensão - UnB) \\
Examinador Externo \\
\hline Profa. Dra. Inara de Oliveira Rodrigues (Dep. Letras e Artes - UESC) \\
Examinador Externo \\
\hline Profa. Dra. Ana Claudia da Silva (TEL-UnB) \\
Examinador Interno \\
\hline Prof. Dr. João Vianney Cavalcante Nuto (TEL-UnB) \\
Examinador Interno \\
\hline Profa. Dra. Virginia Maria Vasconcelos Leal (TEL-UnB) \\
Suplente
\end{tabular}

Brasília/DF, Novembro de 2015. 


\section{FICHA CATALOGRÁFICA}

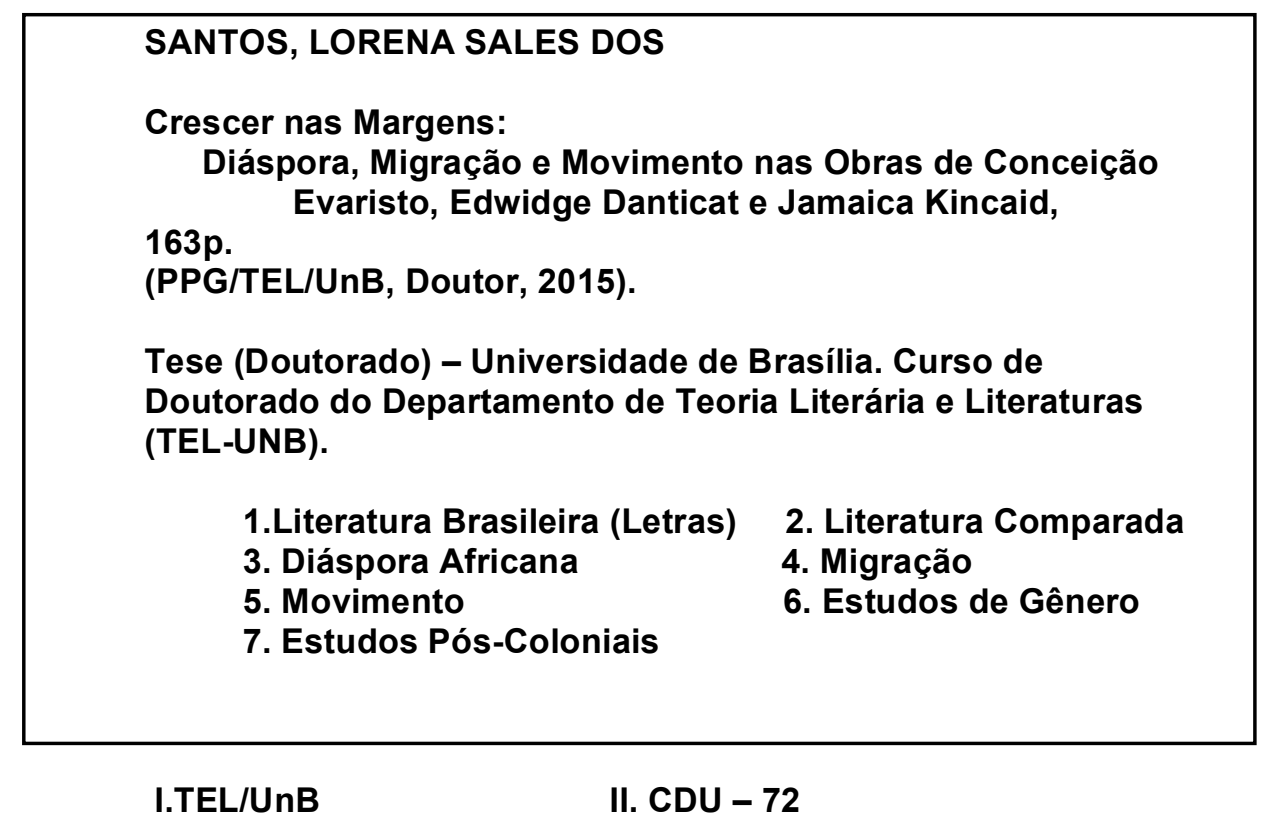

\section{REFERÊNCIA BIBLIOGRÁFICA}

SANTOS, L. S. (2015). Crescer nas Margens: Diáspora, Migração e Movimento nas Obras de Conceição Evaristo, Edwidge Danticat e Jamaica Kincaid. Tese de Doutorado em Literatura, Universidade de Brasília, DF, 163p.

\section{CESSÃO DE DIREITOS}

AUTORA: Lorena Sales dos Santos

TÍTULO: Crescer nas Margens: Diáspora, Migração e Movimento nas Obras de Conceição Evaristo, Edwidge Danticat e Jamaica Kincaid.

GRAU: Doutorado

ANO: 2015

É concedida à Universidade de Brasília permissão para reproduzir cópias desta Tese de Doutorado e emprestar ou vender tais cópias somente para propósitos acadêmicos e científicos. O autor reserva outros direitos de publicação e nenhuma parte desta Tese de Doutorado pode ser reproduzida sem a autorização por escrito do autor.

Lorena Sales dos Santos

CLN 215 BL D SL 41

70.874-540 - Brasília - DF - Brasil

e-mail: Isalesdossantos@gmail.com 
Agradecimentos

\section{AGRADECIMENTOS}

O processo de um doutorado exige dedicação, sacrifício e aprofundamento. Exige que se olhe para o tema da pesquisa dessa forma, mas exige, em consequência, um mergulho em si próprio, um certo isolamento, uma avaliação constante das próprias limitações, uma procura constante, uma busca, para ir mais fundo, para superá-las.

Um doutorado toma espaço, estantes de livros cada vez mais cheias, pilhas de leituras e reflexões, perguntas, respostas, respostas gerando mais perguntas, a ausência de respostas e o tempo. O tempo passa, a vida acontece, indiferente à decisão de se escrever uma tese.

Durante meu tempo como doutoranda, a vida seguiu, a vida não deu pausa e não pediu licença. Minha mãe, já em estado avançado do Mal de Alzheimer, veio morar conosco e, com ela, uma equipe de cuidadores, médicos, enfermeiros, fisioterapeutas, fonoaudiólogos, uma rotina diferente e plena de demandas, administrativas, burocráticas e emocionais. Minha mãe partiu durante o meu doutorado. Com sua partida veio o inevitável e necessário luto, a sensação de ter cumprido a missão e a tomada de decisões burocráticas, administrativas, desgastantes para finalizar os processos exigidos em nossa sociedade quando alguém se vai: Inventário, contas, decisões, saudades e o doutorado.

A decisão de tentar uma bolsa no exterior veio a seguir. Uma decisão que para uma doutoranda, na minha faixa etária, na minha etapa de vida, precisava acontecer como um projeto de família. Não podia ser só eu. Incluía minha filha de cinco anos, na época, e meu marido. Conversas, planejamento, contas a fazer e a decisão de buscar a experiência. Ponderações no âmbito pessoal fizeram parte do processo. Na fila de adoção há quatro anos, fizemos as contas e chegamos à conclusão que ainda esperaríamos, pelo menos, dois anos para que nosso(a) filho(a) chegasse. Então pensamos: "Melhor viver, partir, voltar, enquanto esperamos!"

Seis meses depois, inscrita para a bolsa da Fulbright, segunda fase da seleção, faltando apenas a entrevista, aceita na Indiana University, pela professora doutora Darlene Sadlier, recebo um telefonema da Vara de Infância: "Sua filha chegou!" A vida não espera!

Abrimos os braços e o coração. Novas conversas, novas providências, autorizações judiciais para levar uma criança de um ano e meio para o exterior, uma criança ainda em processo de adoção. Leituras do doutorado, vistos, providências, solicitação de licença do trabalho do marido, escolas e creches, casa nova, língua nova.

Segui para os Estados Unidos dois meses antes do resto da família, Ser mãe pela Internet, pelo Skype não foi fácil e foi preciso conciliar a minha existência virtual com aprendizados, diálogos instigantes, novos colegas, novas ideias, saudades da família, providências para a chegada da família, mais leituras, aulas, longas leituras.

A sensação de que a vida na cidade universitária de Bloomington seria uma experiência transformadora, não só para mim, como para minha 
família, misturava-se com as preocupações com a distância e os efeitos que ela poderia causar. A chegada da família trouxe a constatação da decisão acertada.

A vida nessa pequena cidade cosmopolita, em uma universidade que recebe pessoas do mundo inteiro, a troca de ideias com a minha coorientadora, professora doutora Darlene Sadlier, o importante feedback para o desenvolvimento da minha pesquisa, o contato constante com a professora doutora Carole Boyce Davies, que me trouxe inclusive uma nova escritora para a tese, Edwidge Danticat, meu encontro com ela no Congresso da Associação de Literatura Africana foram experiências enriquecedoras e transformadoras. Além disso, as aulas de Estudos Culturais com a professora doutora Purnima Bose, seus questionamentos, as leituras e os debates com os alunos, me levaram a refletir não apenas quanto aos rumos teóricos da minha pesquisa, mas quanto a forma da escrita de uma tese e o trabalho acadêmico em si.

O contato com pessoas do mundo inteiro em um ambiente em que a pesquisa, os estudos, o ensino e a troca de ideias são as atividades mais importantes me transformaram como pesquisadora e professora. Não sou a mesma depois de Bloomington. Além disso, contar com minha orientadora, professora Cíntia Schwantes e sentir sua presença nas trocas de e-mails e no apoio às minhas decisões durante esse período, sua generosidade e abertura para novas ideias, sua crítica inteligente, sagaz e ao mesmo tempo delicada, foram fundamentais para o desenvolvimento do meu trabalho.

Voltar da experiência da Indiana University com tantas ideias e enfrentar as dificuldades de nosso país no retorno não foi tão fácil quanto o foi ouvir as músicas brasileiras no rádio e constatar a beleza e a riqueza de nossas artes. Mesmo assim, tanto com uma coisa quanto com outra eu tive que lidar. A falta das bibliotecas espaçosas e silenciosas, dos cafés onde as pessoas vão para ler, estudar e debater ideias e projetos, a minha dificuldade pessoal de encontrar um espaço para estudar e produzir, sendo mãe de duas crianças pequenas e vivendo na capital do Brasil, onde o fazer político é mais considerado e valorizado que o pensar político, requereu de mim um esforço pessoal e paciência para a readaptação.

A vida acontece e o doutorado prossegue. Cheguei ao fim dessa etapa. Aqui está o resultado do meu trabalho de mais de quatro anos: Minha tese, uma contribuição minha para os estudos da Literatura da Diáspora Africana, para o entendimento das questões das mulheres negras nos vários espaços dessa diáspora, suas aproximações, suas especificidades, seus distanciamentos.

Cheguei aqui, mas não cheguei só. Durante essa jornada do doutorado, a vida aconteceu, com suas chegadas e suas partidas, e, para que esta tese finalmente viesse a ser, contei com o apoio, o carinho, a presença de muitos. Embora possa parecer que algumas das pessoas citadas aqui não tenham relação com o processo da escrita de uma tese quero enfatizar sua importância, sua contribuição para que a minha vida e o meu doutorado pudessem fluir nesses últimos quatro anos. 
Portanto, agradeço profundamente:

À CAPES e à Fundação Fulbright pelo financiamento a minha pesquisa no Brasil e nos Estados Unidos, durante o período do Doutorado Sanduíche na Indiana University (2012-2013).

À minha orientadora Professora Doutora Cíntia Schwantes, pela competência, dedicação, seriedade, generosidade, pelo carinho e firmeza nas críticas e na orientação, pelo estímulo na busca da experiência do doutorado sanduíche, por ser orientadora presente e amiga e por segurar minha mão enquanto descia o caixão de minha mãe na despedida final. Eu não poderia ter orientadora melhor!

À minha coorientadora na Indiana University (IU), Professora Doutora Darlene Sadlier, por ter me aceitado no programa da IU, tendo me inserido dentro da comunidade acadêmica local com tanto carinho e por ter compartilhado comigo tanto do seu conhecimento, me possibilitando refletir sobre os rumos dos meus estudos e rever o meu caminhar na escrita da tese.

À Professora Doutora Carole Boyce Davies, da Cornell University, pela generosidade com que se disponibilizou a dialogar comigo, por ter desbravado os estudos da escrita das mulheres na diáspora, possibilitando o referencial teórico e uma abordagem da teoria que é a espinha dorsal desta tese. Obrigada pela leitura no início da escrita, pelo feedback inspirador e por acreditar no meu trabalho.

Às professoras doutoras Maria Isabel Edom Pires, Regina Dalcastagné, da Universidade de Brasília, e Professora Doutora Purnima Bose, da Indiana University, pela oportunidade de aprender e trocar ideias em suas salas de aula.

Às professoras doutoras Ana Cláudia da Silva e Virgínia Maria Vasconcelos Leal, da Universidade de Brasília, por participarem da banca de Qualificação e terem oferecido valiosas contribuições.

Às ilhas de Trinidad e Tobago e seus habitantes que me receberam quando eu era estudante universitária de graduação, aos grandes amigos que lá fiz. Viver no Caribe abriu meus olhos para um mundo maior, me fez enxergar a conexão da diáspora africana nas Américas pela primeira vez e foi a semente das minhas reflexões sobre questões étnicas, diversidade e preconceito racial. 
Ao meu marido Roberto, pela paciência, pela fé no meu trabalho, pela disponibilidade de me acompanhar nas aventuras em outros mundos, pelo cuidado e amor com nossa família, pela parceria, pelas leituras atentas, pelo amor incondicional.

Aos meus pais, que me ensinaram o valor do conhecimento e me deram liberdade para pensar, me expressar e ser sempre quem eu sou.

Às minhas filhas, por serem do jeitinho que são, por serem generosas, alegres, por serem luz e amor na minha vida.

Aos meus colegas e amigos da Universidade de Brasília e da Indiana University, pela troca de ideias, pelo apoio, pela ajuda para encontrar bibliografia que não seria possível conseguir não fosse as buscas em bibliotecas no exterior e os envios por e-mail. Agradeço especialmente: Rosilene Silva da Costa, Basak Bingol Yuce, Dereck DiMatteo, Ligia Bezerra Gradoville, Professora Vânia Castro e a Professora Doutora Maria Hamilton (Abegunde).

À Mônica Galvão, por me apoiar desde o mestrado em um processo de autoconhecimento que me possibilitou aprofundar tantas questões pertinentes ao desenvolvimento desta tese.

À Josefa Venâncio que, com seu trabalho e seu carinho, me ajuda a solucionar as questões domésticas para que a vida siga funcionando não apenas dentro da Academia.

Aos amigos de fora da Universidade, pela presença, apoio, carinho, generosidade e paciência de sempre, especialmente: Claudia Cavalcante Weber e Elaine Fonseca que me deram cópias das chaves de suas casas quando eu estava sem local para trabalhar; Cristina Batista Junqueira e Talytta Lisbôa, pelo apoio com as meninas quando eu já estava em Indiana; Claudia Gregori que me indicou o livro "How to survive Reverse Cultural Shock", que muito me ajudou na readaptação pós doutorado sanduíche, e que mandou de Londres as galochas que mantiveram meus pés secos nas idas e vindas ao escritório onde trabalhei o último ano da escrita da tese, lembrando também de André Yugi que as trouxe com tanta disposição e Ana Maria Moraes que me emprestou móveis para o escritório. À amiga e tradutora, Leize Casella Laurenti, e, novamente, ao meu marido Roberto, pela leitura final da Tese quando meu olhar já não mais conseguia enxergar os tropeços, erros de digitação, etc.

Aos amigos da Sunflower Daycare, que compartilharam conosco os cuidados com nossa filha pequena, Sandra, e se tornaram parte da nossa família em Bloomington. À equipe da Templeton Elementary School, especialmente Miss Dunker (hoje, Mrs Hall) e Jiji, 
que acolheram nossa filha Luiza com tanto carinho. Sem a tranquilidade da felicidade das meninas e sua boa adaptação em Bloomington, meu trabalho certamente teria sido prejudicado.

Aos professores, técnicos, membros da equipe Master de Natação e amigos da Academia D'stak que me ajudaram a enfrentar novos desafios, a superar limites, a lidar com o estresse, a relaxar com os mergulhos nas águas que sempre me proporcionaram renovação e que possibilitaram tantos insights. Obrigada por vibrarem com minhas conquistas com tanto carinho e tão genuinamente. 
"We live on an island, Antigua, and on one side runs the Atlantic Ocean and on the other side is the Caribbean Sea. The Atlantic Ocean does not matter much to us. It comes from too far away and it shares itself with too many other people who are too different from us. The Caribbean Sea is ours and we share it with people who live on islands like us, islands that are sometimes made out of coral, sometimes made out of dead volcanoes. All these islands surround the Caribbean Sea like a ring around the rosy pocket full of posey games, preventing it from spilling out into the larger world of seawater. I know there are other seas which seem more important and more special, but they exist for me only in books." ${ }^{1}$

Jamaica Kincaid, The Autobiography of My Mother.

Cresci em um país banhado pelo Oceano Atlântico. Ele sempre me definiu. Em 1993, morei em Trinidad e Tobago e conheci o Mar do Caribe e sua ciranda de ilhas. O Mar do Caribe me ensinou outra forma de ver o mundo, me apresentou outras perspectivas, mas também me disse que o humano está em toda parte. Está aqui e lá. O Mar do Caribe que, para mim, só existia em livros, despertou minha consciência sobre as construções raciais, sobre as fronteiras impostas, as aproximações que precisam ser feitas e as distâncias que devem ser percorridas. O Mar do Caribe hoje também me define. O Mar do Caribe também vive em mim.

Lorena Sales dos Santos

\footnotetext{
1 "Vivemos em uma ilha, Antigua, e de um lado encontra-se o Oceano Atlântico e, do outro lado, o Mar do Caribe. O Oceano Atlântico não é muito importante para nós. Ele vem de muito longe e se divide com muitos outros povos que são muito diferentes de nós. O Mar do Caribe é nosso e nós o dividimos com povos que vivem em ilhas como nós, ilhas por vezes formadas de coral, por vezes de vulcões extintos. Todas essas ilhas circulam o Mar do Caribe como uma ciranda, evitando que se derramem em um mundo oceânico mais amplo. Sei que existem muitos mares que parecem mais importantes e mais especiais, mas, para mim, eles existem apenas em livros." Jamaica Kincaid, The Autobiography of My Mother (Tradução minha).
} 


\section{RESUMO}

A presente tese analisa as aproximações e distanciamentos no processo de formação das protagonistas dos romances Ponciá Vicêncio, de Conceição Evaristo, Breath, Eyes Memory, de Edwidge Danticat, Lucy e The Autobiography of my Mother, de Jamaica Kincaid. Meninas negras, que sofrendo de um sentimento de não pertencer, realizam movimentos diversos impulsionados por esse sentimento. Esse movimento constante foi o que convencionei chamar de "movimento do não pertencimento" e é um dos mais importantes elos entre as narrativas. As protagonistas realizam suas movimentações de modos diversos, em seu crescer: em migrações transnacionais, dentro de seus próprios países ou mesmo em jornadas in situ. Para entender esse movimento constante e o processo dessas meninas em tornarem-se mulheres precisei utilizar um arcabouço teórico complexo que engloba questões relativas aos Estudos Pós-Coloniais, aos Estudos de Gênero, à Teoria Polissistêmica, aos Estudos das Questões Étnico-Raciais, além das questões referentes aos gêneros narrativos do Gótico e do Romance de Formação, no caso aqui estudado, em sua variação póscolonial. Todas essas teorias receberam um tratamento crítico e uma abordagem que permitu seguir com elas apenas a "parte do caminho" que fizesse sentido para a compreensão da trajetória das protagonistas, propondo articulações e indagações que possibilitem entender as conexões de suas experiências como sujeitos diaspóricos e migrantes, mas também compreender suas especificidades.

Palavras-chave: Literatura Comparada, Brasil, Caribe, Diáspora Africana, Estudos de Gênero, Migração, Movimento, Estudos Pós-Coloniais. 


\section{ABSTRACT}

This dissertation analyses the similarities and differences in the process of upbringing of the protagonists of the novels Ponciá Vicêncio, by Conceição Evaristo, Breath, Eyes Memory, by Edwidge Danticat, Lucy and The Autobiography of my Mother, by Jamaica Kincaid. Black girls, suffering from a feeling of not belonging, perform several movements which are propeled by this feeling. This constant movement is what I call "the nonbelonging movement" and is one of the most important links between the narratives. The protagonists perform their movements in many different ways during their growing up process: in transnational migrations, inside their own countries or even in journeys in situ. In order to understand this constant movement and the process this girls undergo to become women, I needed to use a large and complex scope of theories that include topics from Post Colonial Studies, Gender Studies, Polysystem Theory, Studies of Ethnical and Racial matters, as well as studies concerning narrative genres such as the Gothic and the Bildungsroman, here, specifically, in its postcolonial variation. All these theories received a critical treatment and the approach used allowed me to follow, with them, only a "piece of the way", using only what made sense to the understanding of the protagonists' trajectories, proposing articulations and questions that facilitated the comprehension of the connection between their experiences as diasporic and migrant subjects, but also of their specificities.

Key words: Comparative Literature, Brazil, Caribbean, African Diaspora, Gender Studies, Migration, Movement, Post Colonial Studies. 


\section{SUMÁRIO}

Introdução

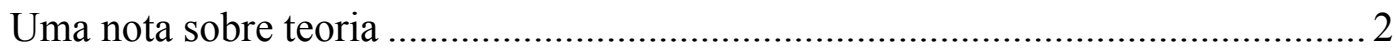

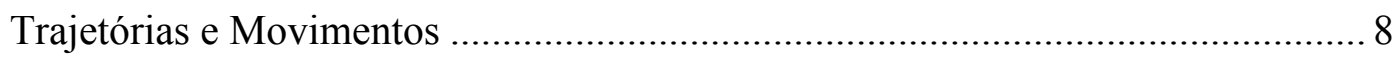

Articulações Identitárias de Gênero, Raça e Etnicidade no Contexto dos Estudos da Diáspora e da Pós-Colonialidade ................................................................. 14

Teoria Polissistêmica: Fluxos e Interferências Centro - Margens - Centro........... 33

Crescer nas Margens - Narrativas de Formação Pós-Colonial .............................. 40

Capítulo 1 Migrações Domésticas...................................................................49

A Diáspora Doméstica de Ponciá Vicêncio ....................................................... 49

The Autobiography of my Mother - O revide dos derrotados............................69

Capítulo 2 Migrações Transnacionais.........................................................................95

Lucy, o anjo caído e as possibilidades infinitas no caminho das identidades múltiplas

Oú Liberé? O fardo da violência sexual e da loucura no crescer de Sophie Caco em Breath, Eyes, Memory

Conclusões

Referências. 


\section{Introdução}

\section{Uma nota sobre teoria}

Lidar com a temática de meninas negras que crescem às margens, em países periféricos, em romances de escritoras negras desses países que são regidos por um sistema de poder patriarcal, que privilegia o homem branco e heterossexual como o principal detentor de poder, aponta para a necessidade de abordar a acumulação de marcas de marginalidade dentro dessas sociedades e, consequentemente, para uma reflexão crítica sobre o marco teórico que fornece suporte a essa empreitada. Essa reflexão precisa avaliar não somente o conjunto de teorias a ser utilizado no trabalho, mas também a forma de abordar essas teorias.

Nesse sentido, para quebrar a tradicional classificação binária, que prescreve apenas duas categorias, teoria e não teoria, Carole Boyce Davies apresenta, em Black Women, Writing and Identity - Migrations of the Subject $1^{1}$ uma definição de "Teoria" como estruturas ou modos de inteligibilidade por meio dos quais podemos ver e interpretar o mundo, ou como formas discursivas que dão sentido a conjuntos de valores e crenças que circulam em uma cultura. Boyce Davies cita também a definição de teorias de Teresa Ebert ${ }^{2}$ que afirma que elas produzem conceitos pelos quais o mundo se torna inteligível e relações sociais específicas são validadas, beneficiando certos grupos e oprimindo outros, mesmo que esta não seja sua intenção. Considerando, portanto, as definições de teoria acima expostas, concordo com Boyce Davies quando defende ser necessário desconstruir todas as teorias, determinando suas origens, intenção e possibilidades.

\footnotetext{
${ }^{1}$ BOYCE DAVIES, Carole. Black Women, Writing and Identity - Migrations of the Subject. New York, Routledge, 1994.

${ }^{2}$ EBERT, Teresa, 1991 (in AIDOO, 1991) apud BOYCE DAVIES, 1994, p.41.
} 
Introdução

Boyce Davies cita situações reais em que pesquisadoras negras, apresentando seus trabalhos na Academia, foram questionadas por pesquisadores homens que alegaram não haver desenvolvimento de teoria por parte delas, salvo raras exceções. A autora defende que a teoria, como apresentada por ela, cria uma oposição a esses argumentos e ressalta também que a natureza da teoria, conforme descrita por Catherine Lutz ${ }^{3}$ mostra-se útil para entender o contexto político em que se inserem as alegações desses acadêmicos. A teoria, segundo Lutz ${ }^{4}$, é toda a escrita que se identifica como "teoria" e é sinalizada de determinada maneira, pela auto rotulação, pela linguagem abstrata e identificada com níveis de dificuldade, pelo estilo e citação do trabalho de outros, e pelo posicionamento do texto em relação a seu momento de origem. Lutz considera que como as mulheres tiveram um acesso tardio à academia, pode-se entender que a definição do que vem a ser teoria não tenha contado com sua participação por séculos e que a voz da mulher ainda sofra resistência e oposição dentro desse meio.

De acordo com Boyce Davies, Lutz ${ }^{5}$ ressalta ainda que a teoria estabelecida sem a participação das mulheres suscita uma ansiedade por uma paternidade e patrilinearidade, e que a própria separação entre o que é "teoria" e "não teoria" imita a oposição entre o masculino e o feminino na sociedade. Tendo em mente a teoria como um domínio historicamente masculino, ela observa que muitas mulheres sentem que, a menos que entrem na discussão teórica nos termos precisamente definidos por essa academia euro-americana dominada pelos homens, suas palavras nunca serão levadas a sério.

Apesar disso, conforme Boyce Davies destaca, é importante considerar que os discursos de gênero e raça da academia nos termos defendidos pelas Mulheres Negras tiveram forte impacto em teorias recentes ligadas ao pós-modernismo e ao feminismo. É possível constatar que muitas das formulações atuais dos discursos de raça, classe, gênero, sexualidade e

\footnotetext{
${ }^{3}$ LUTZ, Catherine, 1990 apud BOYCE DAVIES, 1994, p.39.

${ }^{4}$ Ibid., p.39.

${ }^{5}$ Ibid., p. 39.
} 
Introdução

todo o entendimento da necessidade de se observar mais atentamente a complexidade das subjetividades unitárias, resultaram do discurso crítico de diversos grupos subordinados. Como exemplo desse discurso crítico, Boyce Davies menciona o posicionamento de Audre Lorde em Age, Race, Class and Sex. Women redefining difference, que se relaciona com o que bel hooks ${ }^{6}$ definiu como "discurso crítico" ou "discurso dissidente", que articula as subjetividades com as posições discursivas múltiplas e ambas com a questão da agência. Esse posicionamento não apenas rejeita a subjetividade unitária, mas também reconhece de maneira ativa as relações de poder e a necessidade de agência, resistência e transformação.

Lorde destaca que muito da história ocidental europeia nos condiciona a ver as diferenças humanas em oposições simplistas, como dominador/dominado, bem/mal, superior/inferior. Ela observa que em uma sociedade em que o bem é definido em termos do lucro e não das necessidades humanas, é preciso haver sempre um grupo que, por meio de uma opressão sistematizada, seja situado no local do inferior desumanizado. Dentro do mundo capitalista ocidental, esse grupo é composto de negros e povos do Terceiro Mundo, pessoas da classe trabalhadora, idosos e mulheres. Estou de acordo com Boyce Davies, que considera a posição de Lorde como indubitavelmente teórica, em sua rejeição aos binarismos e identificação das questões de poder e dominação, das opressões relacionadas a classe, raça, gênero, sexo e a outremização, baseando-se em uma teoria social e histórica da diferença como local de luta e conflito social.

A abordagem teórica para uma temática complexa como a da presente tese deve, portanto, funcionar apenas como "seguir uma parte do caminho com eles" 7,8 , o que consiste em aceitar o que se apresenta como útil nas teorias estabelecidas, sem, contudo, perder a visão crítica e sem deixar de realizar intervenções nessas teorias. Não abandonar a teoria ou a teorização, mas oferecer intervenções radicais às reivindicações existentes,

${ }^{6}$ BEL HOOKS, 1989 apud BOYCE DAVIES, 1994, p. 41.

${ }^{7}$ No original: "Go a piece of the way with them".

${ }^{8}$ Tradução minha. 
Introdução

visando completar o conhecimento e, mais ainda, encontrar formas de negociar os vários campos minados teóricos enquanto se cria uma nova definição de identidade da mulher negra, é o que propõe Boyce Davies no que concerne à questão da teoria e é o que norteará este estudo. A proposta de Boyce Davies origina-se da descrição de um modelo de relacionamento com "estranhos" descrito por Zora Neale Hurston" em "How It Feels to Be Colored Me". Nesse modelo, comum a diversas sociedades que tem como base culturas africanas, estabelece-se a cortesia de acompanhar um visitante por uma parte do caminho, a distância sendo definida de acordo com a relação existente. Dentro dessa proposta, o conceito de "discurso crítico" de bel hooks ${ }^{10}$ se mostraria mais valioso que as mais "altas" teorias já estabelecidas, por estar conectado à desconstrução de uma variedade de metanarrativas, tornando-se uma prática que estabelece significados e, portanto, pode ser lida como teoria.

A teoria seria, então, mais útil se os arranjos fossem redefinidos e as localizações renegociadas, o que implicaria em negociar um canal entre a "alta teoria" e a "desconfiança a toda e qualquer teoria". Seria preciso considerar toda teoria em sua própria natureza condicional, pois sem essa consideração ela se torna suspeita, não se arrisca na investigação e circula como uma inquisição administrativa, como descreve Trinh Minh-ha ${ }^{11}$. Seria importante também ressaltar que a teoria oprime ao perpetuar as relações de poder, quando se apresenta como forma de exercer autoridade, como a voz do conhecimento.

Boyce Davies aponta como primeiros conceitos teóricos que apresentam essa possibilidade de reflexão, o seguir uma parte do caminho, como os seguintes conceitos: A "fixação arbitrária", sem a qual não haveria nenhum significado, e o conceito de "articulação", de Stuart Hall ${ }^{12}$. Com relação ao primeiro, é preciso que se reflita quanto a quem fixa e quão arbitrária é a significação fixada, visto que grupos minoritários, como as

\footnotetext{
${ }^{9}$ HURSTON, Zora Neale, 1979 (in WALKER, Alice, 1979) apud BOYCE DAVIES, 1994 p.46.

${ }^{10}$ BEL HOOKS, 1989 apud BOYCE DAVIES, 1994, p. 41.

${ }^{11}$ MINH-HA, Trinh, 1990 apud BOYCE DAVIES, 1994, p.43.

${ }^{12}$ HALL, Stuart, 1985 apud BOYCE DAVIES, 1994, p. 43.
} 
Introdução

mulheres negras, distanciados dos centros de poder, veem os significados impostos sem seu consentimento. A articulação, por sua vez, permite um tipo de conexão aberta e contingente que tem que ser constantemente renovada. Uma articulação pode ser descartada assim que novas conexões, rearticulações, forem forjadas. Boyce Davies afirma que apesar de o termo "articulação" de Hall partir de uma releitura de Althusser e Marx, o posicionamento do autor em termos de provisoriedade assemelha-se à proposta de que se deve seguir parte do caminho com eles. Hall também vê o propósito da teoria como o de ajudar-nos a avançar um pouco mais no caminho.

Outra intervenção teórica mencionada por Boyce Davies é a "Teoria Viajante"13, de Edward Said, que propõe, com base nas ideias de Lukács, Goldman e Raymond Williams, que a teoria pode movimentar-se a partir de seus pontos originais, alcançando novos usos e posições, dependendo do tempo e lugar. Embora o sentido da "teoria viajante" encontre-se presente na crítica cultural e essa metáfora da viagem possa parecer uma metáfora masculina, uma vez que se considere a restrição dos movimentos das mulheres em sociedades tradicionalmente patriarcais, Boyce Davies defende que, para a situação específica das mulheres negras, tanto o ato de "viajar" quanto a "teoria" podem ser identificados como suas prerrogativas.

Uma terceira intervenção, de Homi Bhabha, em defesa da teoria, afirma que o processo de negociação promove a abertura de locais híbridos e objetivos de luta e destrói as polaridades entre teoria e razão práticapolítica, sendo a dicotomia entre política e teoria absurda e desnecessária: “Cada 'posição' é sempre um processo de tradução e transferência de significado. Cada objetivo é construído no rastro da perspectiva que coloca 'sob rasura'[...]"14.

Deleuze, por sua vez, defende que o discurso filosófico, relacionado ao Direito, às instituições e aos contratos, e que subjaz à teoria, nasce do

\footnotetext{
${ }^{13}$ No original: "Travelling Theory".

${ }^{14}$ No original: "Each 'position' is always a process of translation and transference of meaning. Each objective is constructed on the trace of that perspective that it puts 'under erasure'..." (BHABHA, Homi, 1989, p. 119 apud BOYCE DAVIES, 1994, p.44).
} 
Introdução

estado imperial e passa por metamorfoses, sendo, no entanto, parte de uma cultura do sedentário. Há todavia um contradiscurso nomádico que continuamente evade os "códigos dos povos assentados"15, sendo que nem todas as jornadas exigem movimento físico ou a transposição de grandes espaços geográficos, como Deleuze afirma: "algumas viagens ocorrem in situ, são viagens de intensidade."16

Ao mesmo tempo em que reconhece a validade das intervenções de Bhaba e Deleuze, Boyce Davies ${ }^{17}$ observa que não é por acidente que são os homens a reivindicar o direito à teoria e à viagem. A autora ressalta que, ao mesmo tempo em que apoia algumas posições desses teóricos, também reconhece que somos interpelados em uma variedade de discursos que tem como base gênero, raça, sexualidade declarada, etc. e que as hierarquias existentes nos localizam como pensadores, oradores autorizados e teóricos, sendo baseadas nessas mesmas categorias. A autora, por fim, enfatiza a masculinidade como uma das categorias que apresenta maior poder para a garantia de um espaço de audiência.

A proposta de Boyce Davies ${ }^{18}$, no que diz respeito a abordagem teórica, é a de considerar todas as teorias/teóricos como se fossem visitantes, estabelecendo o limite de até onde acompanhá-los no caminho. Ela esclarece que acompanhar muitos dos teóricos pelo caminho inteiro implicaria colocar-se nas "casas" de pessoas onde ela, como mulher negra, só teria função como empregada ou cortesã exótica e silenciada, nunca como uma teórica em igual posição. Sendo assim, ela defende que, ao tratar uma teoria como um visitante, promove-se uma interação semelhante àquela das múltiplas articulações, um tipo de relacionalidade crítica que interroga várias posições teóricas na busca de sua aplicabilidade específica às experiências e textualidades das mulheres negras. Por meio dessa

\footnotetext{
${ }^{15}$ No original: "codes of settled people" (DELEUZE, Giles, 1977 apud BOYCE DAVIES, 1994, p.44-45).

${ }^{16}$ No original: "some voyages take place in situ, are trips in intensity." (DELEUZE, Giles, 1977 apud BOYCE DAVIES, 1994, p.45)

${ }^{17}$ BOYCE DAVIES, 1994.

${ }^{18}$ Id., 1994.
} 
Introdução

abordagem torna-se possível estabelecer negociações dentro de um questionamento específico com o ecletismo que se faz necessário.

Acompanhar por parte do caminho, conforme sugerido por Hurston $^{19}$, e já mencionado anteriormente, é uma articulação que pressupõe determinada agência. Essa agência, por sua vez, proporciona uma jornada que favorece uma consciência relativa à migração, à mobilidade, ao movimento, à partida, ao retorno e à re-partida, conforme Trinh T. Minh-ha ${ }^{20}$, e também acarreta certa transformação, como acrescenta a própria Boyce Davies.

Dentro dessa perspectiva de seguir "uma parte do caminho com eles", abordo as questões teóricas neste trabalho de pesquisa, buscando sempre levar em consideração as especificidades da representação das experiências das meninas/mulheres negras protagonistas dos romances em foco, dos países periféricos a que pertencem e dos movimentos e processos migratórios dos quais são sujeitos, realizando tanto revisões quanto articulações que se façam necessárias para a análise de suas complexas experiências.

\section{Trajetórias e Movimentos}

O tráfico negreiro do período colonial foi responsável pela dispersão dos povos da África em inúmeros lugares do mundo. Essa migração forçada e a sujeição a séculos de escravidão resultou em apagamentos das especificidades relativas à origem, tornando aos de ascendência africana quase impossível a identificação de seu pertencimento a tribos, religiões, idiomas, etc. Sendo assim, terminou-se por criar uma origem conectada a uma África mítica, monolítica, uma África imaginada, que seria a terra mãe de todos os descendentes de africanos espalhados pelo mundo. Boyce Davies $^{21}$ aponta a adoção dessa África monolítica como um certo

\footnotetext{
${ }^{19}$ HURSTON, Zora Neale, 1979 (in WALKER, Alice, 1979) apud BOYCE DAVIES, 1994, p.46.

${ }^{20}$ MINH-HA, Trinh, 1990 apud BOYCE DAVIES, 1994, p.47.

${ }^{21}$ BOYCE DAVIES, 1994, p. 10.
} 
Introdução

gerenciamento da realidade, uma forma de resistência à dominação europeia, que construiu uma identidade alternativa.

Boyce Davies ${ }^{22}$ ressalta ainda que a necessidade de entender as várias resistências à dominação eurocêntrica de modo transnacional e de criar "um outro lugar" está incrustada na formulação da diáspora. Segundo a autora, Paul Gilroy ${ }^{23}$ em sua revisão de Benedict Anderson, vê a própria estrutura da diáspora como "uma alternativa às diferentes variedades de absolutismo que confinariam a cultura em essências nacionais, étnicas ou raciais" ${ }^{24}$. A comunidade panafricana criou condições para uma "comunidade imaginada" que é, por um lado, ligada a uma terra natal unificada e por outro à diáspora. De modo semelhante, as migrações de muitos povos de suas terras natais por razões econômicas ou políticas criam condições de exílio e demandam a criação de novas comunidades com novas relações estabelecidas com a terra natal.

A análise do crescer de meninas negras em romances de escritoras negras de países diversos, que é objeto desta tese de doutoramento, almeja estabelecer uma comparação das trajetórias das protagonistas dos romances Ponciá Vicêncio, de Conceição Evaristo ${ }^{25}$; Breath, Eyes, Memory, de Edwidge Danticat ${ }^{26}$; e Lucy e The Autobiography of My Mother, de Jamaica Kincaid $^{27}$. As escritoras são, respectivamente, do Brasil, do Haiti e da Antigua. Países esses que, embora tenham sido colonizados por diferentes metrópoles, guardam semelhanças em seus processos históricos de colonização e foram receptores da diáspora africana, sendo o Brasil a maior população com origem africana fora da África ${ }^{28}$.

O estudo aqui apresentado analisa as aproximações nas trajetórias das protagonistas, ocasionadas pelos contextos similares relativos às

${ }^{22}$ BOYCE DAVIES, 1994, p.10.

${ }^{23}$ GILROY, Paul, 1987 apud BOYCE DAVIES, 1994, p. 13.

${ }^{24}$ GILROY, Paul, 1987 apud BOYCE DAVIES, 1994, p. 13.

${ }^{25}$ Ponciá Vicêncio. Belo Horizonte: Mazza Edições, 2003.

${ }^{26}$ DANTICAT, Edwidge. Breath, Eyes, Memory. New York: Vintage Contemporaries, 2 ed, 1998.

27 KINCAID, Jamaica, Lucy. New York: Farrar Straus Giroux, 2002. The Autobiography of my Mother. New York: Plume/Penguin, 1997.

${ }_{28}$ Demografia da América Latina. Disponível em: <http://pt.wikipedia.org/wiki/Demografia da_América_Latina>. Acesso em 07/08/2014. 
Introdução

situações econômicas, históricas e culturais de países periféricos, patriarcais, ex-colônias de exploração, de onde são originárias. Ao mesmo tempo, problematiza a geografia pela qual os mapas criados pelos colonizadores contribuíram para manter separações produzidas artificialmente, visto que a ascendência dessas meninas conectada à escravidão, ao trauma do apagamento das origens e ao preconceito étnico também produzem um contexto que aproxima suas experiências.

Embora se mostre importante verificar as semelhanças e conexões no crescer dessas meninas nos romances em foco, aproximando as experiências das mulheres negras no mundo, também os afastamentos, as diferenças, são foco da minha pesquisa. As trajetórias dessas meninas não são lidas aqui como alegoria nacional, mas como trajetórias de indivíduos. A comparação dos seus processos de crescimento e suas movimentações objetiva apresentá-las como personagens únicas, visando contribuir com possibilidades diversas da representação das meninas e mulheres negras no mundo.

Sem isso, concordo com Boyce Davies ${ }^{29}$, continuaremos presos às definições dos termos "Negro", ou "Americano" ou "minoria" como estabelecidos no discurso dominante, seja ele o discurso androcêntrico europeu, seja ele o discurso feminista negro americano, que embora tenha sido extremamente importante em seus questionamentos, não deixa de criar outras hierarquias que posicionam a mulher negra americana como paradigma da experiência da mulher negra no mundo. Por esse motivo, a análise das diferenças também faz parte do presente estudo. Como tornamse mulheres essas meninas que se deparam com o patriarcado e o racismo em seu crescer? Como lidam com o passado diaspórico? Qual é sua capacidade de agência? Qual o papel da educação? Como enfrentam as dificuldades? Como se movimentam no mundo em que habitam? O que acarreta o movimento na vida de cada uma delas? Foram algumas das perguntas feitas durante o processo de escrita desta tese.

${ }^{29}$ BOYCE DAVIES, 1994. 
Para entender a experiência das personagens, o movimento tornouse uma questão central e mostrou-se, de fato, o eixo conector entre elas. As protagonistas dos romances, além de terem sua origem conectada à diáspora africana, sendo portanto sujeitos diaspóricos, como conceitua Stuart Hall, tornam-se também sujeitos migrantes, conforme conceito de Carole Boyce Davies ${ }^{30}$.

A força propulsora que impulsiona esses movimentos é ligada a uma clara sensação de não pertencimento experimentada por todas as protagonistas, em diferentes níveis. A sensação de não pertencer, de falta de lugar, aparece primeiramente na relação das meninas com o seu passado histórico, com as origens e a ancestralidade. Essa relação é demonstrada como importante em todas as narrativas. Há sempre relatos do passado dos pais, dos avós, histórias de sofrimento e dor conectadas à escravidão e ao processo de colonização.

A quebra na conexão com a ancestralidade e o estabelecimento de uma identidade forçada com o nome do opressor, o senhor de escravos, remetem a um tempo em que seus antepassados eram considerados posse e perpetuam essa marca de "inferioridade" dentro de um sistema social. Embora não sejam mais escravas, as meninas têm os sobrenomes dos donos dos escravos. Dentro de uma sociedade que se organiza pela patrilinearidade na nomeação, elas precisam dos sobrenomes para circular socialmente, mas não se identificam com eles, pois eles são a lembrança diária do trauma da escravidão. Esse é, portanto, um modo perverso de perpetuar a dominação do colonizador, infiltrar-se na própria identidade do dominado.

O retorno às origens africanas é interdito, visto que, com a vinda dos povos africanos como escravos às Américas, as narrativas orais específicas se perderam e o que pôde ser resgatado se tornou pertencente de modo monolítico a todos. As especificidades foram assim apagadas, transformando uma variedade de tribos e etnias em um bloco só. Por esse

${ }^{30}$ Id., 1994. 
motivo, estabelecer uma conexão com as origens e o passado pré-trauma, pré-escravidão, torna-se uma questão tão importante para esse grupo.

O movimento Back to Africa foi uma tentativa frustrada de uma recuperação das origens. Os que voltaram à África tiveram, entretanto, que passar pela dura experiência de reconhecer o não pertencimento também a essas origens. Constatou-se assim que não havia mais lugar garantido na terra-mãe, pois a distância que se impôs pelo tempo impedia uma total reinserção. O passado recente da escravidão, todavia, também não proporciona um lugar confortável no país para onde os negros foram levados, e a abolição da escravatura não criou condições para que os escravos libertos fossem inseridos na sociedade com plenos direitos. De modo geral, o que ocorreu foi o estabelecimento de estruturas que perpetuaram a desigualdade e mantiveram os negros em condições subalternas e mesmo semelhantes às do período escravocrata. Ponciá, protagonista de Ponciá Vicêncio ${ }^{31}$ descreve a situação de agregados em que vive sua família, a falta de condições no campo para a comunidade em que vive, as disputas e manipulações sofridas pelos afrodescendentes no que diz respeito à posse da terra, a decisão de tentar a vida na cidade grande e a impossibilidade de ascensão que acaba encontrando. Lucy, de Lucy $^{32}$ e Sophie Caco, de Breath, Eyes, Memory ${ }^{33}$ precisam migrar para outro país para terem chance de desenvolvimento e ascensão social. Lucy vai só, enquanto Sophie precisa viver anos separada da mãe, que migra primeiro. Migram para os Estados Unidos, país que funciona, de certo modo, como uma atualização da posição da metrópole colonizadora. Xuela, de The Autobiography of my Mother ${ }^{34}$ (KINCAID, 1997), embora não saia da ilha do Caribe em que nasceu, movimenta-se por toda a ilha e realiza também uma intensa jornada interior em busca de seu espaço próprio, deparando-se e enfrentando as diversas limitações impostas pelo sistema pós-colonial e patriarcal.

\footnotetext{
${ }^{31}$ EVARISTO, 2003.

${ }^{32}$ KINCAID, 2002.

${ }^{33}$ DANTICAT, 1998.

${ }^{34}$ KINCAID, 1997.
} 
É importante ressaltar que não pretendo com este trabalho esgotar as possibilidades para entender a realidade nem das protagonistas, nem das mulheres negras no mundo. Ao contrário, de modo conjuntural e provisório, minha intenção é contribuir para expandir a rede de conhecimento a esse respeito, fornecendo visões alternativas do que pode ser a experiência de crescer como mulher negra, promovendo uma visão pluralista, sem contudo desconsiderar o passado histórico de dominação, o bloqueio ao acesso à educação e à saúde, a violência física e simbólica contínua, o racismo e o patriarcalismo. Tendo em mente, portanto, as conjunturas que unem as experiências dessas protagonistas, pretendo explicitar os elos que as conectam e as especificidades de suas trajetórias, suas estratégias de resistência e sobrevivência, suas possibilidades de movimento, suas migrações e os fatores que, por vezes acarretam uma imobilização.

Defendo que há em comum na representação de suas experiências um sentimento de "não pertencimento" que impulsiona um movimento constante a que chamo de "movimento do não pertencimento". Esse não pertencimento é a força propulsora de deslocamentos, que se constituem como buscas de um espaço próprio, físico e simbólico, provocando rompimentos familiares que geram abandono do lar e mudanças de casa, migrações domésticas, transnacionais e mesmo profundas transformações internas, viagens in situ. Entretanto, embora não se mostrem à vontade nos seus pontos de partida, os pontos de chegada também se mostram como locais de conflito e, para que a adaptação no novo local ocorra com sucesso, é necessário que as fragmentações e múltiplas identidades sejam conciliadas ou, ao menos, reorganizadas. Quando isso não acontece, ou enquanto isso não acontece, as personagens não avançam e permanecem vivenciando seus traumas repetidas vezes. Por outro lado, a aceitação dessa fragmentação e a reunião de recursos adequados em espaços favoráveis podem oferecer oportunidades de desenvolvimento extraordinárias para essas meninas.

Algumas áreas de estudos e conceitos teóricos específicos mostraram-se importantes para que se possa acompanhar o crescer das 
meninas negras dos romances em foco e seus movimentos, embora, como explicitado anteriormente, pretenda-se sempre seguir apenas a parte do caminho que faça sentido para entender as correlações e as especificidades de suas experiências. A seguir, apresento algumas reflexões sobre os estudos pós-coloniais, os estudos de gênero, a diáspora, os conceitos de raça e etnia, a teoria polissistêmica e o Romance de Formação Pós-colonial. Tópicos esses que se mostraram fundamentais para a consecução da análise crítica dos romances. Na seção específica de análise, esses conceitos serão retomados e mais particularmente discutidos à luz das narrativas.

\section{Articulações Identitárias de Gênero, Raça e Etnicidade no Contexto dos Estudos da Diáspora e da Pós-Colonialidade}

O uso do termo "pós", em estudos pós-coloniais, é objeto de acesa discussão, posto que o prefixo em seu sentido primeiro, o de depois do colonial, não contempla as reflexões quanto aos períodos englobados nos estudos da área. Os estudos pós-coloniais como utilizados na presente tese dizem respeito às articulações "entre" e "através" dos períodos históricos politicamente definidos como pré-colonial, colonial (podendo estender-se às culturas pós-independência) e, mais recentemente, o neocolonialismo dos dias de hoje, conforme apresentado por Eloína Santos ${ }^{35}$, em seu ensaio Pós-Colonialismo e Pós-Colonialidade.

A definição de Pós-colonialismo de Santos $^{36}$, com a qual estou de acordo, precisa incluir uma consideração ampla das diferentes sociedades pós-coloniais com suas agendas e forças internas próprias que interagem e modificam as respostas às diversas incursões coloniais, tendo em mente assim as questões locais, suas preocupações e práticas. Não se pode ignorar que cada encontro colonial foi diferente e que cada ocasião póscolonial tem que ser localizada com precisão e analisada com especificidade.

\footnotetext{
${ }^{35}$ SANTOS, Eloína, 2005 (in FIGUEIREDO, 2005).

${ }^{36}$ Ibid., 2005.
} 
Introdução

A mudança de poder nas ex-colônias demandou uma descolonização simbólica na qual a literatura toma parte relevante. Dando expressão à experiência do colonizado, os escritores pós-coloniais procuram subverter tanto a temática quanto a forma dos discursos que sustentaram a expansão colonial, os mitos de poder, raça e subordinação, entre outros. A Literatura pós-colonial apresenta as marcas profundas da exclusão e da dicotomia cultural do período de dominação imperial, além de mostrar as transformações acarretadas pelo domínio cultural colonial e os conflitos delas resultantes.

Como as conquistas coloniais eram, em geral, definidas por conflitos militares, deslocamentos populacionais sem precedentes e pela exploração das riquezas locais, a resistência à dominação por aqueles que careciam de armas ou dinheiro se deu textualmente. Os primeiros nacionalistas contraescreveram sua representação colonial e reinscreveram-se nessa nova história com recriações épicas do passado.

O livro The Empire writes back ${ }^{37}$, de 1989, que é mencionado por Santos $^{38}$, fornece diversas definições dos tipos de experiências coloniais inglesas que podem ser úteis para o estudo das literaturas produzidas nas ex-colônias. O primeiro tipo de colônia tratado é a colônia de assentamento, que tem como exemplo a maioria dos países das Américas, a Austrália e a Nova Zelândia. Nesse tipo de colônia, uma das primeiras tarefas foi produzir uma literatura separada daquela produzida nos centros metropolitanos. O segundo tipo trata da colônia de assentamento profundo, tendo como exemplos, a Argélia, a Índia, o Quênia, a Jamaica e a Indonésia, sendo incluídos aqui também a Antigua e o Haiti (locais de origem de Jamaica Kincaid e Edwidge Danticat), onde houve mais forte repressão das línguas e culturas locais e uma imposição mais acentuada do inglês ou do francês, das suas literaturas e culturas e onde a expressão local só pôde ser

${ }^{37}$ ASHCROFT, B., GRIFFITHS, G., and TIFFIN, H. The Empire Writes Back: Theory and Practice in Post-Colonial Literatures. Londres, Routledge, 1989. ASHCROFT, B., GRIFFITS, G. et TIFFIN, H., 1989 apud SANTOS, 2005 (in FIGUEIREDO, 2005).

${ }^{38}$ SANTOS, 2005 in FIGUEIREDO, 2005. 
recuperada com os movimentos de independência após a Segunda Guerra Mundial.

Na América Latina, por sua vez, como ainda explanado por Santos ${ }^{39}$, os Estudos pós-coloniais se iniciaram na segunda metade do século XX com Mary Louise Pratt, Diana Brydon e Walter Mignolo, entre outros, trabalhando com a ideia de "descolonização do conhecimento". Para Pratt ${ }^{40}$, o termo póscolonialismo mostra-se útil quando é possível fazer reflexões críticas sobre as manobras do colonialismo as quais não eram possíveis anteriormente. De acordo com Santos ${ }^{41}$, o lado negativo do termo apontado por Pratt ${ }^{42}$, é que assim como com outros "pós", como o pós-moderno, pós-guerra-fria, pósmarxismo, etc., o "pós-colonial" autoriza um certo desengajamento de alguns intelectuais metropolitanos e cosmopolitas, possibilitando que continuem a desempenhar, inconsequentemente, o papel de centro do mundo, definindo todo o resto como periferia.

Como intelectual, trabalho a ideia da pós-colonialidade na presente tese, aliando-a à perspectiva da teoria polissistêmica de Itamar Even-Zohar ${ }^{43}$ que considera não apenas a existência de diversos centros em vários polissistemas, mas também a ocorrência frequente de interferência de sistemas periféricos em sistemas centrais, atuando em eixos tanto sincrônicos quanto diacrônicos e permitindo uma visão menos fixa dos fenômenos pós-coloniais. A teoria polissistêmica também facilita as articulações necessárias e encontra-se em consonância com a proposta de abordagem teórica de Carole Boyce Davies ${ }^{44}$, já anteriormente mencionada, que funciona como eixo condutor deste trabalho. Voltarei à questão do polissistema com mais detalhes ainda nesta introdução.

Leela Gandhi ${ }^{45}$ ressalta que o pós-colonialismo passou a constituir um dos principais discursos críticos da humanidade apenas na última

\footnotetext{
${ }^{39}$ SANTOS, 2005.

${ }^{40}$ PRATT, Mary Louise, 1999 apud SANTOS, 2005 (in FIGUEIREDO, 2005).

${ }^{41}$ SANTOS, op. cit.

${ }^{42}$ PRATT, Mary Louise, op. cit.

${ }^{43}$ EVEN-ZOHAR, Itamar, Polysystem Studies, volume 11, nr 1, Poetics Today, Durham, North Carolina: Duke Press, 1990

${ }^{44}$ BOYCE DAVIES, 1994.

${ }^{45}$ GANDHI, Leela apud SANTOS, 2005.
} 
década do século $X X$, chegando a essa posição ao lado de teorias como o pós-estruturalismo, a psicanálise e o feminismo e, por sua natureza interdisciplinar, vem gerando um enorme corpus de literatura acadêmica marcado pelo debate entre o marxismo e o pós-estruturalismo/pósmodernismo, sem que nenhum dos lados tenha, de fato, dado conta dos resultados do encontro colonial. O crítico pós-colonial tem, portanto, que trabalhar em direção a uma síntese, a uma negociação entre o modelo de pensamento pós-estruturalista, considerando a epistemologia ocidental, a teorização das diferenças e da alteridade cultural; e o modelo marxista, com sua filosofia materialista, que parece suprir as bases da política pós-colonial.

Desse modo, a ideia de Boyce Davies ${ }^{46}$ de seguir uma parte do caminho com eles no que diz respeito às questões teóricas comprova-se ainda mais como estratégia fundamental, visto que para realizar um trabalho crítico lidando com o arsenal dos estudos pós-coloniais é indispensável estabelecer articulações e reconhecer limites, sempre que necessário. Isso é válido também para todas as demais teorias que compõem o arcabouço teórico para a análise crítica do crescimento, da formação e dos movimentos das meninas negras aqui estudadas, sejam as teorias conectadas à questão racial, étnicas, sejam as ligadas aos estudos de gênero. Articulação torna-se de fato uma palavra chave, além da negociação entre diversos aspectos teóricos, para que se possa dar conta da complexidade temática apresentada pelas narrativas em foco.

O feminismo, por exemplo, conforme verbete "feminism and postcolonialism", em Key Concepts in Post-Colonial Studies ${ }^{47}$, pode mostrar-se de interesse crucial para o discurso pós-colonial, pois como o sistema patriarcal e o colonialismo exercem formas análogas de dominação sobre aqueles a quem submetem, as experiências das mulheres no patriarcado e dos sujeitos colonizados mostram-se paralelas, sendo que tanto o feminismo quanto as políticas pós-coloniais opõem-se a essa dominação. Além disso, pode-se considerar que a situação da mulher dentro de um sistema colonial e patriarcal acarreta uma situação classificada por uma "dupla

${ }^{46}$ BOYCE DAVIES, 1994.

${ }^{47}$ ASHCROFT el al., 1998. 
colonização" ${ }^{\prime 8}$, resultado da opressão acarretada não apenas por ser sujeito colonizado, mas também por ser mulher. Sendo assim, para efeito desta tese, entendo a posição das protagonistas dos romances em foco como meninas sujeitas a uma "tripla colonização", visto que se acumulam, nelas, a opressão sofrida pelo sujeito colonial que é, além disso, mulher e negra.

$\mathrm{O}$ verbete "feminism and post-colonialism" aponta ainda a maneira como tanto o pós-colonialismo e o feminismo se preocupam com o quanto e de que modo a representação e a linguagem mostram-se cruciais à formação da identidade. Com relação a esta questão, mostra-se fundamental incluir os discursos da luta antirracista que também demonstram a mesma preocupação e acompanham os discursos do póscolonialismo e do feminismo nessa reflexão sobre a construção da subjetividade. A linguagem funciona como um veículo para subverter não só o discurso patriarcal e o poder imperial, de que falam Ashcroft et al, mas também para desconstruir as construções étnico-raciais. Esses discursos partilham, assim, um trabalho de desarticulação de uma linguagem que Ihes foi imposta, ao mesmo tempo em que podem utilizar-se do mecanismo de apropriação para subverter e adaptar linguagens dominantes e práticas de significação.

A conexão entre feminismo, pós-colonialismo e etnia é posteriormente apontada por Ashcroft et al. ${ }^{49}$ quando citam Domitila Barrios de Chungara ${ }^{50}$. Ela ressalta que a superposição da opressão racial, patriarcal e econômica sempre foram difíceis de negociar e que as diferenças de prioridades políticas de mulheres do primeiro e terceiro mundo persistem. No entanto, pode-se considerar que essas diferenças sejam mais ligadas a questões de ênfase e estratégia do que a questões de princípios, visto que a interconexão de muitas formas de opressão social afetam de modo material a vida de todas as mulheres.

Um relato que facilita a compreensão das conexões entre raça e gênero como consequência da expansão colonial encontra-se em Black

\footnotetext{
${ }^{48}$ Ibid., p.103.

${ }^{49}$ ASHCROFT el al., 1998.

${ }^{50}$ CHUNGARA, Domitila Barrios de, 1977 apud ASHCROFT et al, 1998.
} 
Bodies, White Bodies, de Sander L. Gilman ${ }^{51}$. Essa obra mostra como a representação do(a) africano(a) na literatura, artes plásticas e na medicina do século XIX reforçou a construção de um corpo feminino sexualizado, tornando-o um ícone para os "desvios" sexuais em geral. Nas colônias de povoamento, embora os corpos das mulheres brancas não fossem diretamente construídos como parte de uma sexualidade transgressiva, eram frequentemente objeto de um discurso de poder de outra natureza. Críticos como Whitlock ${ }^{52}$ observaram que os corpos femininos brancos eram percebidos reduzidamente como reprodutivos, literalmente considerados os "ventres do Império" cuja função era povoar as colônias de brancos. Ressalto que os corpos das mulheres negras, além de serem percebidos como sexuais, sendo assim facilitado o abuso e o estupro por parte dos colonizadores, podem também ser considerados, no período colonial, como corpos reprodutores, mas de mão de obra escrava útil para a economia colonial.

A presença dos corpos femininos negros nas Américas colonial e pós-colonial é resultado da diáspora africana acarretada pelo tráfico negreiro que sustentou a economia colonial por vários séculos. Sendo assim, compreender a diáspora é de suma importância para a análise da trajetória das protagonistas das narrativas aqui estudadas. As personagens têm sua origem conectada a essa diáspora, assim como ocorre com as escritoras dos romances.

Para principiar essa reflexão, recorre-se à comparação da Diáspora Africana a uma revolta simbólica contra o estado-nação, estabelecida por Michael Hanchard ${ }^{53}$. Para ele, a diáspora sugere uma dimensão transnacional da identidade negra. Nas palavras de Hanchard: "[...] se a ideia de uma diáspora africana é algo, ela é um colar humano unido por um fio conhecido como o tráfico de escravos, um fio que atravessou a América

${ }^{51}$ GILMAN, Sander L., 1985 apud ASHCROFT et al, 1998.

${ }^{52}$ WHITLOCK, 1995 apud ASHCROFT et al., 1998, p.104.

${ }^{53}$ HANCHARD, 1990 apud BOYCE DAVIES, 1994. 
Introdução

com pouca atenção às fronteiras nacionais." ${ }^{54,55}$. As fronteiras do nosso discurso, segundo Boyce Davies ${ }^{56}$, mostram que operamos de modo limitado a partir de uma realidade que é muito mais complexa do que aquela por ele apresentada. Termos como "minoria", usado nos EUA, "negro", na Grã Bretanha, e "imigrante", em geral, têm poder apenas quando se aceita a limitação imposta pelas sociedades dominantes ou quando são usados como reapropriação tática para resistência. Ao observar o significado de "negro" em um contexto geopolítico diaspórico que inclua, além da América do Norte, as Américas do Sul e Central e o Caribe, poderíamos falar de um contexto transnacional que elimina o status localizado de minoria e reconhece o termo como uma tentativa de transpor o status identitário do estado-nação para as identidades transnacionais. Essa dinâmica de localização e reconexão oferece um novo e mais contraditório conjunto de perguntas e respostas.

Boyce Davies $^{57}$, em concordância com Kobena Mercer, enxerga cadeias de significado diversas em cada comunidade. Nessas cadeias há uma luta na linguagem que revela um antagonismo discursivo no qual se encontram em jogo a identidade e a subjetividade. Essa luta pelo signo não chega a um fim e não se pode considerar nenhum termo como definitivo para responder aos discursos do racismo e etnocentrismo, visto que o Outro pode apropriar-se do que foi primeiramente apropriado pelos grupos étnicos em luta contra o racismo. Concordo com Boyce Davies quando ressalta a importância de manter um questionamento constante quanto aos significados, resistindo ao fechamento e mantendo a abertura a novos significados e contestações, pois para combater a realidade do imperialismo é necessário reconhecer outros discursos e alianças que evitem a armadilha das fronteiras identitárias locais/nacionais prescritas.

\footnotetext{
${ }^{54}$ No original: "[...] if the notion of an African diaspora is anything it is a human necklace strung together by a thread known as the slave trade, a thread which made its way across a path of America with little regard for national boundaries." (Id., 1990)

${ }^{55}$ Tradução minha.

${ }^{56}$ BOYCE DAVIES, 1994.

${ }^{57}$ Id., 1994.
} 
Introdução

O conceito de sujeito diaspórico é também útil para entender o caminhar das protagonistas dos romances aqui analisados. A partir de sua relação pessoal com a Inglaterra e a Jamaica, Stuart Hall ${ }^{58}$ entende e elabora esse conceito, sendo o sujeito diaspórico aquele que conhece os dois lugares intimamente, mas não pertence completamente a nenhum dos dois. Hall afirma ser justamente essa a experiência do sujeito diaspórico, o estar longe o suficiente para experimentar uma sensação de exílio e perda, mas próximo o suficiente para compreender o enigma da chegada sempre adiada. Tem-se assim, como afirma Simmel, citado por Hall, a experiência de estar dentro e fora, ser o "estranho familiar" $59,60$.

A pós-colonialidade, de acordo com Hall ${ }^{61}$, preparou o sujeito para viver em uma relação diaspórica ou pós-moderna com sua identidade. De modo paradigmático, isso é uma experiência diaspórica, pois do mesmo modo que a imigração se mostrou o evento histórico mundial da modernidade tardia, a experiência clássica pós-moderna é a experiência diaspórica. Ele ressalta também que a ida de uma classe trabalhadora negra caribenha para a Inglaterra foi uma diáspora da diáspora, pois o Caribe já é resultado de uma diáspora oriunda da África, Europa, China, Índia e outras regiões da Ásia. Sendo que essa diáspora se "rediasporizou"62 na vinda dos caribenhos para a Inglaterra. Aqui incluo também os movimentos paralelos de migração para a França e Estados Unidos, que é o destino da migração das personagens Lucy $^{63}$ e Sophie $\mathrm{Caco}^{64}$. Até mesmo, a migração de Ponciá Vicêncio ${ }^{65}$, intranacional, pode ser lida como paralela a essa segunda diáspora, se considerada a dimensão continental do Brasil, as diferenças profundas entre nosso meio rural e as grandes metrópoles brasileiras e os números do êxodo rural brasileiro.

\footnotetext{
${ }^{58}$ CHEN, Kuan-hsing, 1996.

${ }^{59}$ No original: "familiar stranger".

${ }^{60}$ Ibid., p.490.

${ }^{61}$ Ibid., p.490.

${ }^{62}$ No original: "re-diasporized".

${ }^{63}$ KINCAID, 2002.

${ }^{64}$ DANTICAT, 1998.

${ }^{65}$ EVARISTO, 2003.
} 
Introdução

No que tange a questão da identidade cultural, Stuart Hall ${ }^{66}$ defende que ela não seja algo fixo, mas sempre híbrido. No entanto, precisamente porque tem sua origem em formações históricas específicas de histórias e repertórios de enunciação culturais muito particulares é que a identidade cultural pode constituir uma "posicionalidade", que podemos chamar, provisoriamente, de identidade. Dessa forma, cada uma dessas históriasidentidades encontra-se inscrita nas posições que adotamos e com as quais nos identificamos. Assim, de acordo com Hall ${ }^{67}$, faz-se necessário ao sujeito diaspórico viver esse conjunto de posições-identidades em todas suas especificidades. As questões identitárias dos sujeitos da diáspora são perpassadas pelas questões raciais e étnicas que serão abordadas a seguir.

O conceito moderno de raça, conforme apresentado por Kwame Appiah $^{68}$, tem como base a época vitoriana durante a qual a maioria dos intelectuais acreditava que os seres humanos podiam ser divididos em grupos menores denominados "raças". Acreditava-se que os membros desses grupos compartilhavam certas características intelectuais e morais biologicamente herdadas e não compartilhadas com nenhum membro de outra raça. Essas características em conjunto eram consideradas a essência da raça. Esse pensamento racialista, base do pensamento da maioria dos cientistas ocidentais no século XIX, pregava que a essência de uma raça era responsável não apenas pelas características externas, físicas, mas por outras características como inteligência e honestidade.

O século $X X$ é herdeiro desse pensamento, embora para as ciências, tanto biológicas quanto antropológicas, o conceito de raça não possua de fato nenhuma correspondência com algo que a ciência reconheça como real. Além disso, as classificações como negro, caucasiano ou mongol não têm nenhuma importância em termos biológicos. Isso não quer dizer que não se possa ter uma discussão sobre raça no campo da literatura, aceitando sua irrealidade e que a maior parte das informações sobre o

\footnotetext{
${ }^{66} \mathrm{Id}, 1996$.

${ }^{67} \mathrm{Id}, 1996$.

${ }^{68}$ APPIAH, Kwame, 1990 (in LENTRICCHIA, Frank et MCLAUGHLIN, Thomas, 1990).
} 
conceito são falsas, principalmente porque, conforme afirma Appiah ${ }^{69}$ : “[...] raças são como bruxas: independente do quão irreais são as bruxas, a crença nelas, como a crença nas raças, tem tido, e em muitas comunidades continua a ter, profundas consequências pra a vida social humana. ${ }^{70,71}$.

Ainda de acordo com Appiah ${ }^{72}$, as ideias sobre raça poderiam, em princípio, ter se desenvolvido sem o pressuposto da superioridade de uma raça sobre a outra, embora não tenha ocorrido dessa maneira. Na metade do século XIX, a visão de que todas as raças eram dotadas da mesma capacidade era a visão de uma minoria, apesar de o cristianismo pregar a ancestralidade comum a todos os seres humanos e de o lluminismo enfatizar a universalidade da razão. Mesmo aqueles que insistiam na igualdade de direitos para todos os seres humanos, acreditavam que os povos não brancos não possuíam nem a mesma inteligência, nem o mesmo vigor das raças brancas.

No seu capítulo sobre Raça, Appiah ${ }^{73}$ realiza uma breve análise da questão racial em diversas obras, como The Tempest, de Shakespeare, Ivanhoe, de Sir Walter Scott, Salammbô, de Gustave Flaubert, entre outras, procurando demonstrar a conexão do pensamento racialista na literatura com a formação do conceito de nação e apresentando esse pensamento em diferente estágios. Para o autor, nação é um termo chave para se entender a relação entre o conceito de raça e a ideia da literatura. Com a crescente influência das ciências naturais no século XIX, aquilo que era comum nos seres humanos, a chamada "natureza humana", passou a ser concebido cada vez mais em termos biológicos e antropológicos. Sendo assim, a nação passou, inevitavelmente, a ser identificada como uma unidade biológica, definida pela essência compartilhada que flui a partir de um ascendente comum.

\footnotetext{
69 APPIAH, Kwame, op. cit.

70 "[...] races are like witches: however unreal witches are, belief in witches, like belief in races, has had - and in many communities continue to have - profound consequences for human social life." (Ibid., p.277)

71 Tradução minha.

${ }^{72}$ APPIAH, Kwame, op. cit.

${ }^{73}$ APPIAH, Kwame, op. cit.
} 
Introdução

Para o propósito desta tese não se justifica entrar em detalhes da análise das obras realizadas por Appiah ${ }^{74}$. É interessante, no entanto, observar sua defesa da importância de examinar o papel das questões raciais nos estudos literários, especialmente na literatura norte-americana e assim analisar o modo como essa literatura e os estudos literários refletem a existência de grupos étnicos cujos contornos são, de certo modo, produto do racismo. Embora a noção de raça seja mítica, não é possível negar o fato de que possuir certas características hereditárias, como a cor da pele escura em oposição a possuir o cabelo loiro (como no exemplo fornecido por Appiah $^{75}$ ), ou, acrescento, ter o cabelo crespo em vez de liso no Brasil, acarreta profundas consequências sociais, econômicas e psicológicas, principalmente em sociedades não apenas racialistas, mas também sexistas.

É fundamental compreender que mesmo que muito do que seja dito sobre raças hoje, nos Estados Unidos, como aponta Appiah ${ }^{76}$, ou em outros países como o Brasil, seja literalmente falso, se entendido como referente a raças biológicas, pode ainda ser interpretado, nessas sociedades, como afirmações verídicas sobre grupos sociais, como ocorre com os afroamericanos, judeus-americanos ou asiáticos-americanos (nos EUA), cujas experiências de vida e relações políticas são fortemente determinadas pela existência de estereótipos racistas. Não é dado como exemplo pelo autor, mas aqui poderia ser incluída também a categoria do "latino" que engloba todos os imigrantes da América Latina, seja ela de colonização espanhola ou portuguesa, com características físicas que se assemelhem ao estereótipo latino determinado, fortemente, pela visão americana da ampla migração mexicana.

Appiah $^{77}$ concentra-se, contudo, naquilo que considera a mais proeminente reflexão da etnicidade racialmente compreendida nos estudos literários dos últimos anos, que é o desenvolvimento da crítica literária afroamericana. $\mathrm{O}$ autor defende que a corrente em defesa do nacionalismo afro-

\footnotetext{
${ }^{74} \mathrm{APPIAH}$, Kwame, op. cit.

${ }^{75}$ Id., 1990.

${ }^{76}$ Id., 1990.

${ }^{77}$ Id., 1990.
} 
Introdução

americano tem sido acompanhada pelo apelo a uma cultura de herança africana expressa pela música e a poesia negras, ao ponto de os afroamericanos serem pensados como um povo separado. Com o avanço do racialismo, Appiah ${ }^{78}$ enfatiza, isso tornou-se mesmo inevitável e o pensamento do século XIX propôs o nacionalismo como reflexo desse status separado. Uma vez que o nacionalismo negro se expresse nessa forma, torna-se inevitável que uma literatura nacional consistindo da arte popular dessa raça [sic] deva ser considerada a mais alta expressão do espírito negro nacional.

Há, no entanto, outra razão apontada por Appiah $^{79}$, pela qual a identificação de uma história da produção literária negra mostra-se central não apenas à crítica literária afro-americana, mas à cultura dos afroamericanos em geral. Uma poderosa tradição intelectual europeia e americana consistentemente negou a capacidade dos povos negros de contribuir para o mundo das artes e das letras. Antes mesmo do estabelecimento da raça como um conceito biológico, figuras influentes haviam expressado suas dúvidas quanto à capacidade do negro de produzir literatura. Mesmo durante o lluminismo, quando se enfatizou a universalidade da razão, pensadores como Voltaire, Kant e Thomas Jefferson negaram a capacidade literária dos povos de ascendência africana. Uma vez que a raça passou a ser conceitualizada em termos biológicos, essas opiniões sobre o povo negro levaram à crença de que essas incapacidades eram parte de uma essência racial da qual não se podia escapar. Em resposta a essa infâmia continuada, os escritores negros norte-americanos, desde Phillis Wheatly ${ }^{80}$, vêm buscando estabelecer a "capacidade do Negro" escrevendo e publicando literatura.

O reconhecimento do anglo-saxonismo e do racismo na construção do cânone literário estudado nos departamentos de Inglês das universidades americanas levou muitos acadêmicos a defenderem a inclusão de textos afro-americanos nesse cânone, em parte porque sua exclusão era uma

\footnotetext{
${ }_{78}^{78}$ APPIAH, Kwame, 1990 (in LENTRICCHIA, Frank et MCLAUGHLIN, Thomas, 1990).

${ }^{79}$ Ibid., 1990.

${ }^{80}$ Primeiro poeta africano-americano que viveu em Boston no final do século XVIII.
} 
Introdução

expressão de racismo. Por outro lado, encontram-se acadêmicos que defendem o reconhecimento de uma tradição afro-americana da escrita, com seus próprios textos maiores, que pode ser estudada como um cânone em si. Duas motivações parecem, segundo $A_{p p i a h^{81}}$, estar por trás dessa defesa. Uma delas, ligada ao movimento Black Aesthetic ${ }^{82}$, é motivada por um nacionalismo negro que, em parte, é uma resposta ao racismo. A segunda demanda o reconhecimento de um cânone negro porque identifica características formais nos textos de escritores negros que derivam de uma consciência dos seus predecessores literários negros e das tradições populares afro-americanas. É importante considerar que, apesar de os debates em torno de uma tradição literária afro-americana serem pautados em termos da existência de uma tradição de textos esteticamente valiosos que foram ignorados, a questão do cânone afro-americano é política. A política do nacionalismo anglo-saxão excluiu a cultura afro-americana do cânone oficial americano e atualmente existem debates nos movimentos negros sobre a conveniência ou não da inclusão da literatura afro-americana no cânone.

Embora o foco da reflexão de Appiah $^{83}$ seja os Estados Unidos, a tradição literária americana tem sido receptora de muitos escritores da diáspora que se instalam nesse país, inclusive das duas escritoras caribenhas que fazem parte do presente estudo. Sendo assim, a discussão mostra-se pertinente, assim como as conclusões de Appiah que observam que as diferenças entre os povos, assim como as diferenças entre comunidades dentro de uma sociedade, têm um papel fundamental no pensar quem somos, na estruturação dos nossos valores e na determinação das identidades por meio das quais vivemos.

Appiah prossegue considerando que o racismo e nacionalismo, conjuntamente, tiveram um papel central em um período de cento e cinquenta anos (de 1840 a 1990) quanto à forma de pensar essas diferenças, sendo que uma das contribuições do nacionalismo foi considerar

\footnotetext{
${ }^{81}$ APPIAH, Kwame, 1990.

${ }^{82}$ Estética Negra (tradução minha).

${ }^{83}$ Id., 1990.
} 
a literatura como central à vida nacional. Desse modo, a raça tornou-se central à literatura e ao pensamento sobre a literatura nesse período.

Foi justamente esse racialismo que, no século $X X$, possibilitou os linchamentos no sul dos Estados Unidos, sustentou o Estado racista na África do Sul e também levou aos horrores do Holocausto. Acrescento ainda, que é esse racialismo que, ainda hoje, possibilita que um menino negro de quinze anos seja espancado, tenha parte de sua orelha cortada e seja abandonado nu e acorrentado a um poste no Rio de Janeiro, por um grupo de "justiceiros" que o acusou de pequenos furtos na região. ${ }^{84}$

Ressalto, entretanto, que a mais profunda aversão a esses desastres morais não significa necessariamente o fim do racismo. Como exemplificado pela opinião do próprio presidente americano Barack Obama, a eleição de um homem negro como presidente dos Estados Unidos, embora uma conquista, também não significa o fim do racismo nesse país. Obama declarou, em 2012: "Eu nunca acreditei que por estar sendo eleito, estaríamos de algum modo entrando em uma era pós-racial." ${ }^{25,86}$. Sendo assim, a questão racial deverá continuar a ser uma preocupação não apenas para a história literária dos séculos $\mathrm{XIX}$ e $\mathrm{XX}$, mas também para o século $\mathrm{XXI}$.

Além do conceito de raça, o conceito de etnicidade é fundamental para a análise de narrativas com protagonistas negras e diaspóricas como as que compõem o corpus desta tese. No que diz respeito à etnicidade, é importante ter em mente que ela não deve ser definida por si só, pois se refere não a algo em si, mas a uma relação. É com essa ressalva que Werner Sollors inicia o Capítulo 20, intitulado Etnicidade (Ethnicity, no Original), do livro Critical Terms for Literary Study ${ }^{87}$. A etnicidade é definida então por contraste. Sollors explica que se todos os seres humanos

\footnotetext{
${ }^{84}$ BELCHIOR, N., "Menino negro é espancado e amarrado nu em poste na Zona Sul do Rio", Afroativismo na Rede: Liberdade e direitos humanos, Carta Capital. Disponível em: http://negrobelchior.cartacapital.com.br/2014/02/04/menino-negro-e-espancado-e-amarradonu-em-poste-na-zona-sul-do-rio/. Acesso em 07 de agosto de 2014.

${ }^{85}$ No original: "I never bought into the notion that by electing me, somehow we were entering into a post-racial period"

${ }^{86}$ New York Times, 04 de maio de 2012.

${ }^{87}$ SOLLORS, W., 1990 (in LENTRICCHIA, Frank et MCLAUGHLIN, Thomas, 1990).
} 
Introdução

fizessem parte de um só grupo étnico, não existiria a necessidade de um termo como esse, embora ainda pudessem ser usados outros critérios para estabelecer diferenças como idade, sexo, classe, local de nascimento, etc.

As identificações étnicas, raciais ou nacionais estabelecem-se com base na antítese, na negatividade ou no que, de acordo com Sollors, Georges Devereux chamou de caráter "dissociativo". A identidade étnica, desse modo, é o produto lógico e histórico da asserção de que "A é um membro de $X$ porque ele não faz parte de $Y^{\prime \prime 88,89}$. Sendo assim, torna-se fácil identificar a "Xisidade"90,91, o que seria o identificador do ser X. Além disso, a identificação de $X$ como não $Y$ ameaça exagerar as diferenças de tal modo que se os Xs se pensarem como humanos, facilmente poderão pensar nos Ys como não humanos. A não ser que a equação seja contrabalançada com uma aceitação positiva do seu oposto "B é um membro de $Y$ porque ele não é membro de $X^{\prime \prime 22,93}$, a identificação contrastiva pode eliminar a humanidade compartilhada pelos diferentes grupos e erigir fronteiras simbólicas semelhantes às existentes entre humanos e animais ou entre seres vivos e não vivos.

O termo grego ethnos, que deu origem às palavras etnia e etnicidade, como ressaltado por Sollors, contém uma ambivalência entre o sentido inclusivo, ou seja "o povo em geral", e o sentido dissociativo "outro povo", por exemplo: não-judeus (os goim), não cristãos, os pagãos, etc. No mundo moderno, a distinção geralmente encontra-se na antítese entre indivíduos do grupo não concebido etnicamente e as coletividades étnicas (os grupos de fora).

Assim como Appiah ${ }^{94}$, no seu ensaio Raça, do mesmo Critical Terms for Literary Studies, Sollors afirma que a etnicidade junto ao nacionalismo espalhou-se com particular intensidade desde os tempos da Revolução

\footnotetext{
${ }^{88}$ Tradução minha.

89 " $A$ is an X because he is not a Y". (SOLLORS, W., 1990, p. 288 (in LENTRICCHIA, Frank et MCLAUGHLIN, Thomas, 1990)).

90 Tradução minha.

91 "Xness" (lbid., p.288).

92 Tradução minha.

93 " $\mathrm{B}$ is a $\mathrm{Y}$ because he is not a X" (Ibid., p.288).

${ }^{94}$ APPIAH, 1990 (in LENTRICCHIA, Frank et MCLAUGHLIN, Thomas, 1990).
} 
Introdução

Francesa e Americana, tendo permanecido uma força na história política desde então. O poder burguês, diferentemente do poder da aristocracia, dependia de um interesse compartilhado entre pessoas que poderiam nunca se encontrar, mas que sentiam-se conectadas pela literatura, por meio de jornais, manifestos e músicas populares, assim como peças de teatro, poemas e romances que desempenhavam importante papel na sustentação de um sentimento de pertencimento. Pode-se mesmo afirmar, de acordo com Sollors ${ }^{95}$, que a etnicidade e o etnocentrismo são, de fato, os produtos de exportação de maior sucesso da Europa e da América do Norte. O enfraquecimento de formas específicas de pertencimento local, consequência dos processos de urbanização e modernização, fortaleceu as identificações em formas mais abstratas e generalizadoras como as identificações étnicas e nacionais.

Ao lidar com as questões identitárias relativas à etnicidade, Boyce Davies $^{96}$, por sua vez, aborda a Negritude (Blackness) ${ }^{97}$ ou Africanidade, apontando esses conceitos como uma asserção tática, embora, por vezes, essencializada, que propõe justamente uma oposição à esmagadora branquitude ou supremacia europeia. Todavia, é preciso ter em mente que os termos em que os povos africanos não ocidentalizados negociam suas identidades não são aqueles que representam essa Blackness, mesmo quando embaixo do grande guarda-chuva da identidade homogênea "Africana". Sendo assim, o termo Negro deve ser acionado de maneira provisional e relacional e baseado na localização ou posição. Isso não significa que o termo não possa ser usado de modo oposicional e como resistência toda a vez que a branquitude buscar despolitizar-se e normalizarse.

Com respeito ao termo Blackness, Boyce Davies também questiona o apagamento da identidade adicional da mulher no termo e aponta que é justamente essa identidade adicional, a de gênero, que interfere na

\footnotetext{
95 SOLLORS, 1990.

96 BOYCE DAVIES, 1994.

97 O termo continuará sendo citado em inglês, visto que difere de Negritude como tradução do movimento francófono.
} 
uniformidade da identidade negra e que portanto é ignorada, apagada ou tutelada. A autora menciona Butler e reflete que se concordarmos com ela e entendermos a categoria da mulher como uma de performance de gênero, então as categorias "mulher negra" ou "mulher de cor" existem como performances múltiplas de gênero, raça e sexualidade baseadas nas comunidades de classe, geopolíticas, históricas e culturais em que as mulheres negras existem.

Após a discussão dos termos Negro e Blackness, Boyce Davies ${ }^{98}$ passa a tratar do termo "Africano-americano", utilizado mais recentemente nos Estados Unidos (termo que influenciou também o uso no Brasil de "afrobrasileiro"). A autora discute as implicações e significados implícitos no termo "americano" que foi apropriado de forma imperialista pelos EUA e em seguida trata do termo "africano", mais importante para este trabalho, afirmando que este tem importância como definição apenas em oposição ao que é europeu ou ao que é americano. Historiadores africanos indicam que o termo inicialmente era o nome de um pequeno grupo étnico na Tunísia e que começou a ser aplicado a uma área geográfica maior que incluía o que hoje é o leste do Marrocos até a Líbia. A observação da arqueologia e genealogia do termo "África" mostra-se como exercício fundamental para o entendimento de como as políticas de conquista e dominação encontram-se profundamente conectadas com os processos de nomeação. Na diáspora, sob a influência de ideologias pan-africanas, a reconstrução da África como terra natal ocorreu também para um certo gerenciamento da realidade, pois, como resistência à dominação europeia, construções monolíticas da África mostraram-se uma identidade alternativa.

Os múltiplos povos do Caribe oferecem interessantes formas pósmodernas de entender a identidade. Além disso, a história dessa região no contexto das Américas, entendida como uma história de genocídio, escravidão e brutalidade física, como no reconhecimento de Jamaica Kincaid

${ }^{98}$ BOYCE DAVIES, 1994. 
Introdução

em $L u c y^{99}$, exige um entendimento de cultura como oposição ou resistência e, mais ainda, como transformacional para a recuperação de quaisquer identidades além daquelas impostas. Edouard Glissant ${ }^{100}$, citado por Boyce Davies, descreve o Caribe como "a Outra América".

Boyce Davies também enfatiza que as identidades caribenhas são produto de numerosos processos de migração. Como resultado, pode-se concluir que o Caribe é menos uma localização geográfica e mais uma construção cultural baseada em uma série de misturas, línguas e comunidades. Sendo assim, por vezes, se fala em criolização ("creolization") ou mestiçagem ("métissage") como sendo a característica definidora fundamental do Caribe. Todavia, os termos crioulo e mestiço já carregam suas próprias negatividades e associações com posições na hierarquia racial, se usados em relação a outras populações negras em certos países, como o Brasil.

Ao transpor a questão da identidade étnica para o contexto literário, retoma-se aqui uma posição de Sollors ${ }^{101}$. O autor aponta que a abordagem étnica da escrita corre sempre o risco de uma generalização, podendo estabelecer que um determinado escritor, por exemplo, escreve como $\mathrm{X} \mathrm{e}$ não como $Y$, e que essa Xisidade constitui uma qualidade de status místico, a-histórico e de uma essência quase-eterna. A Literatura, dessa maneira, desempenha um papel central na naturalização do processo moderno de dissociação étnica e pode ajudar a criar a ilusão da existência "natural" de um grupo desde tempos imemoriais.

Sollors ${ }^{102}$ analisa o romance $A$ Connecticut Yankee in King Arthur's Court, de Mark Twain, para exemplificar questões referentes à construção da etnicidade. Não sendo necessário entrar nos detalhes dessa análise para o estudo dos romances em foco nesta tese, é interessante observar que o autor utiliza esse texto canônico para demonstrar os processos simbólicos

\footnotetext{
99 "Eu tinha percebido que a origem da minha presença na ilha, minha história ancestral era o resultado de um ato torpe..." (KINCAID, 1991, p.135 apud BOYCE DAVIES, 1994, p. 1). Tradução minha.

${ }^{100}$ GLISSANT, Edouard, 1989 apud BOYCE DAVIES, 1994, p. 12.

${ }^{101}$ SOLLORS, 1990.

102 Id., 1990.
} 
que ajudam a constituir os contrastes étnicos. Embora a questão étnica seja frequentemente associada com as obras de escritores cuja ascendência os torna membros de grupos étnicos minoritários, os processos geradores dos sentimentos de pertencimento dissociativo estão presentes e apoiam diversos outros textos literários. Assim, o estudo da "etnicidade" na literatura pode ir além de meramente demonstrar a Xisidade de $X$, nos textos de escritores descendentes de $\mathrm{X}$, ou de fornecer suporte aos modelos puristas do século XIX de culturas totalmente baseadas na etnicidade.

As abordagens puristas contemporâneas ao mesmo tempo que têm como base os ataques aos cânones etnicamente exclusivos do passado, replicam por vezes o foco de seus antagonistas na Xisidade dos autores, que serve como a base da avaliação da literatura e da construção de suas tradições. Como afirma Sollors ${ }^{103}$, todavia, a própria ideia de pureza étnica é uma invenção moderna que nunca se aplicou a muitos autores; e os críticos dessa abordagem de grupo, que se mostra estreita, têm ilustres ancestrais, como Goethe, com seu conceito de "literatura mundial" que, no entanto, não geraram muitos resultados institucionais na vida acadêmica moderna. Nesse sentido, apesar da criação de alguns departamentos para o estudo geral da literatura e da literatura comparada, o estudo da literatura continua organizado dentro das fronteiras nacionais e étnicas.

O caráter inventado da etnicidade moderna pode se tornar mais claro, como ressalta Sollors ${ }^{104}$, por meio de uma variedade de abordagens dos textos canônicos e não canônicos. Estudos dos motivos e temas dos textos podem contribuir para uma compreensão das estruturas simbólicas e imaginativas que intensificam, ou mesmo geram, a consciência grupal em coletividades dominantes ou subjugadas ou que vivenciam confrontos hostis. Ao mesmo tempo essas pesquisas podem revelar a extensão em que as ditas literaturas étnicas, frequentemente estudadas de forma isolada, compartilham um repertório de linguagem literária disponível.

${ }^{103}$ SOLLORS, 1990.

${ }^{104}$ Id., 1990. 
Os novos trabalhos históricos podem evitar que se fechem algumas obras hermeticamente em chaves étnicas puras, e ajudar a abandonar a ficção que afirma que autores de um grupo étnico só são influenciados por autores desse mesmo grupo. Em vez disso, as abordagens comparativas podem auxiliar a compreensão do desafio das fronteiras na tradição literária e subverter as atitudes proprietárias com base no conceito de raça. Ressalto aqui que não apenas Sollors ${ }^{105}$, mas também Boyce Davies ${ }^{106}$ enxerga de modo favorável a utilização dos estudos de literatura comparada como forma de transpor as fronteiras artificialmente estabelecidas e conectar a experiência da diáspora negra, resignificando assim termos como negro e minoria, possibilitando conectar experiências e estabelecer paralelos, assim como reconhecer peculiaridades.

\section{Teoria Polissistêmica: Fluxos e Interferências Centro - Margens - Centro}

De extrema utilidade para realizar um estudo comparativo que evite o fechamento das obras literárias em chaves étnicas puras e facilite o entendimento quanto à maneira com que os diversos produtos de grupos étnicos diferentes interferem ou sofrem interferência uns dos outros, é a teoria polissistêmica elaborada por Itamar Even-Zohar ${ }^{107}$.

Para Even-Zohar, os fenômenos semióticos, tais como padrões de comunicação humanos governados pelos signos (linguagem, cultura, literatura, sociedade), podem ser mais bem entendidos e estudados se forem enxergados como sistemas em vez de conglomerados de elementos díspares. A abordagem desses sistemas deve ser realizada por meio de uma perspectiva funcionalista que tenha como base a teoria dos sistemas dinâmicos e não a teoria dos sistemas estáticos.

\footnotetext{
105 SOLLORS, 1990.

106 BOYCE DAVIES, 1994.

107 EVEN-ZOHAR, Itamar, Polysystem Studies, volume 11, num. 1, Poetics Today, Durham, North Carolina: Duke Press, 1990.
} 
Introdução

Para diferenciar essas duas teorias aplicadas ao Funcionalismo, Even-Zohar afirma ser a última relacionada com a tradição saussuriana, concebendo "sistema" como uma rede estática (sincrônica) de relações, na qual o valor de cada item é uma função da relação específica de que faz parte, e eliminando o fator de sucessão do tempo (a diacronia) do "sistema", deixando, assim, o fator histórico excluído dos estudos linguísticos. Apesar de se mostrar limitada, em comparação com a mera coleta de dados positivista, a que se opôs, a abordagem estática proporciona uma visão das condições sob as quais opera um sistema em um determinado momento do tempo e para este propósito pode ser considerada eficiente.

A abordagem dos sistemas dinâmicos, por sua vez, introduz os aspectos históricos na abordagem funcional e considera a operação do sistema tanto em princípio quanto em tempo. A inclusão do aspecto histórico na abordagem funcional acarreta diversas implicações, tais quais:

1- A admissão de que tanto a sincronia quanto a diacronia são aspectos históricos, não podendo mais a sincronia ser considerada como estática, visto que, a qualquer momento, mais de um grupo de fatores diacrônicos opera no eixo sincrônico.

2- O entendimento de que um sistema consiste tanto de diacronia quanto de sincronia, sendo que tanto uma quanto outra consistem por si só em um sistema.

3- A idéia de sistemicidade e estruturação não mais identificada com homogeneidade, podendo um sistema semiótico ser concebido como uma estrutura aberta e heterogênea, necessariamente um polissistema.

Even-Zohar ${ }^{108}$ descreve então o polissistema como:

um sistema múltiplo, um sistema de vários sistemas que se intersectam uns com os outros e em parte se sobrepõem, usando concorrentemente diferentes opções, ao mesmo tempo que funciona como um todo estruturado, cujos membros são interdependentes. ${ }^{109,110}$

\footnotetext{
${ }^{108}$ Even-Zohar, 1990.

${ }^{109}$ Tradução minha.
} 
O polissistema, dentro dessa abordagem dinâmica, concebe 0 sistema como heterogêneo e dinâmico, enfatizando a multiplicidade de intersecções e maior complexidade estrutural envolvida. Trabalhando com sistemas abertos, o nível de análise exaustiva pode ser mais limitado, mas abre espaço para mais "desordem" e para as possibilidades de mudança desses sistemas.

Uma abordagem que não considere os polissistemas, mas apenas um uni-sistema, em geral desconsidera os sistemas periféricos como extrasistêmicos, considerando como importante apenas aquilo que pertence à cultura oficial, à língua padrão, à literatura canônica e aos padrões estabelecidos pelas classes dominantes, em geral branca, europeia e androcêntrica. Esse tipo de abordagem acarreta a não percepção das tensões inerentes à relação dos estratos de um mesmo sistema e dos processos de mudança resultantes dessa relação. Visto que essas relações são desconsideradas do sistema, os processos de mudança têm que ser explicados como invenções individuais de mentes criativas e a mudança efetiva não pode ser interpretada, pois sua natureza não aparece aos olhos do observador.

Para Even-Zohar ${ }^{111}$, o estudo dos sistemas deve considerar sua relação hierárquica dentro do polissistema e a luta permanente entre os vários estratos dessa hierarquia, sendo a vitória de um estrato sobre outro exatamente o que caracteriza mudança no eixo diacrônico. Por meio de movimentação centrífuga e centrípeta, fenômenos periféricos podem ser trazidos para o centro de um sistema, enquanto outros, centrais, podem ser levados à periferia. Há também a possibilidade de movimentação de um fenômeno a partir da periferia de um determinado sistema, ou mesmo polissistema, para a periferia de outro sistema/polissistema.

$\mathrm{O}$ autor aponta as oposições entre os diversos estratos como o equilíbrio regulador dos diversos sistemas, aquilo que impede que os

110 "a multiple system, a system of various systems which intersect with each other and partly overlap, using concurrently different options, yet functioning as one structured whole, whose members are interdependent." (EVEN-ZOHAR, 1990, p.11)

${ }^{111}$ EVEN-ZOHAR, 1990. 
sistemas entrem em colapso ou desapareçam. Paradoxalmente, é a pressão de sistemas não-canônicos que promove a sobrevivência de sistemas canônicos, estes evitam a estagnação e evoluem por não poder ignorar as pressões dos sistemas periféricos que ameaçam sua posição. Como exemplo, podemos considerar as novas narrativas escritas por mulheres negras originárias de sistemas periféricos, como Jamaica Kincaid e Edwidge Danticat no sistema literário norte americano, e Conceição Evaristo no sistema literário brasileiro. Essa evolução é, por vezes, a única forma de preservação. Quando a pressão dos sistemas periféricos não encontra um canal, geralmente, o sistema canônico ou é gradualmente abandonado com a canonização de outro sistema ou entra em colapso total por meio de uma revolução que o derruba. Sem o estímulo de uma forte "subcultura", ou da "cultura popular", qualquer atividade canônica tende a se petrificar, não permitindo que o sistema atenda às necessidades de mudança da sociedade a qual pertence.

Via de regra, o centro de um polissistema corresponde exatamente ao repertório canônico de maior prestígio. Esse grupo governa então o polissistema, determinando a canonicidade de um certo repertório. Com a determinação do que é canônico, o grupo ou adere às propriedades do repertório por ele canonizado ou as altera, conforme necessidade, para manter sua posição central. No caso de falhar nas duas alternativas acima mencionadas, o grupo é afastado por algum outro grupo que lhe toma a posição central, canonizando outro repertório.

O repertório, no sistema literário, é definido por Even-Zohar ${ }^{112}$ como um conjunto de leis e elementos (modelos totais, conectados ou individuais) que governam a produção de texto. O repertório pode ser canonizado ou não, enquanto o sistema a que o repertório pertence pode ser central ou periférico. Quando os repertórios canonizados encontram-se nos sistemas centrais, é possível falar por abreviação em sistemas canônicos e nãocanônicos. Apesar de alguns elementos e leis parecerem universalmente válidas desde o surgimento das primeiras literaturas do mundo, um número

${ }^{112}$ EVEN-ZOHAR, 1990. 
grande de elementos e leis encontra-se sujeito a alterações em diferentes períodos e culturas. É nesse setor local e temporal do repertório que ocorrem as tensões e lutas no sistema literário ou em qualquer outro sistema semiótico.

A seleção do que é ou vai ser canonizado em um repertório não é inerente ao próprio repertório. É fruto de relações sistêmicas que determinam o status de certos objetos e que determinam um certo conjunto de características que devem ser consumidas por um certo grupo. Pensando assim, a literatura não pode ser considerada como um mero conjunto de textos, é preciso pensá-la como um polissistema do qual textos e repertório são apenas manifestações parciais explicadas quando se tem em mente as relações sistêmicas que incluem os responsáveis pela produção, o público e as instituições que determinam os valores simbólicos dos textos.

Even-Zohar ${ }^{113}$ apresenta dois tipos diferentes de canonicidade, uma estática, que se refere ao âmbito dos textos e outra, dinâmica, que age no âmbito dos modelos. No primeiro caso, um certo texto, aceito como produto finalizado, é inserido em um conjunto de textos santificados que a Literatura ou a Cultura pretende preservar. No segundo caso, um certo modelo literário consegue estabelecer-se como princípio produtivo no sistema por meio de seu repertório. É a canonização dinâmica que de fato gera o cânone (grupo de sobreviventes das lutas pela canonização) e que é crucial para a dinâmica do sistema.

Segundo o autor, quando um repertório se estabelece e todos os seus modelos derivativos são construídos em total acordo somente com o que é permitido por ele, esse sistema é um sistema conservador. Todo produto originário desse sistema será altamente previsível, enquanto qualquer desvio será considerado um ultraje, um produto chamado por Even-Zohar de secundário. Por outro lado, a expansão e reestruturação de um repertório por meio da introdução de novos elementos, que torna seus produtos menos previsíveis, demonstra a capacidade de inovação desse

${ }^{113}$ EVEN-ZOHAR, 1990. 
Introdução

repertório e do sistema a que pertence. Os modelos oferecidos nesse repertório são primários, inovadores, e a pré-condição para que funcionem é justamente a descontinuidade dos modelos estabelecidos ou, pelo menos, de elementos deles. O autor ressalta que uma vez que um modelo primário seja admitido no centro de um sistema canônico, ele rapidamente se torna um modelo secundário desde que seja perpetuado por tempo suficiente. É importante considerar que as lutas entre modelos primários e secundários são tão importantes para a evolução do sistema quanto as tensões e lutas entre os estratos baixos e altos encontrados no âmbito desse sistema.

Outra importante questão abordada por Even-Zohar é a das interrelações e intrarelações sistêmicas. O autor entende por interrelações aquelas que envolvem dois tipos de sistemas adjacentes, um conjunto que pertence a uma única comunidade e um conjunto, ou suas partes, que pertence a outras comunidades. As intrarelações, por sua vez, tem como base a pressuposição de que qualquer (poli)sistema semiótico (língua ou literatura, por exemplo) é apenas um componente de um (poli)sistema maior, como o da Cultura, sendo subjugado por este e isomórfico a ele, correlacionado com o todo maior e seus outros componentes. Dessa forma, a teoria do polissistema oferece hipóteses para a forma como a literatura se relaciona e correlaciona com a linguagem, a sociedade, a economia, a política, a ideologia, entre outros.

Não há mais necessidade de enxergar a literatura como expressão unidirecional, imediata e unívoca dos fatos sociais. Ao contrário, observa-se a existência de intrincadas correlações isomórficas e funcionais no todo cultural, que realizam trocas constantes de maneira frequentemente oblíqua, por meio de transmissões e usualmente via periferias. O sistema literário, considerado na teoria polissistêmica como isomórfico ao sistema social, possui hierarquias que intersectam as hierarquias do sistema social e é considerado, como qualquer outro sistema sociocultural, como um sistema simultaneamente autônomo e heterônomo em relação aos outros sistemas com os quais possui correlação. Even-Zohar ${ }^{114}$ fornece o exemplo da

\footnotetext{
${ }^{114}$ EVEN-ZOHAR, 1990.
} 
instituição literária (formada por ideologias literárias, editoras, críticos, grupos literários ou quaisquer outros grupos ou formas de ditar o gosto ou fornecer normas), que mesmo se comportando inegavelmente como um sistema sociocultural semindependente, obedecendo suas próprias leis, tem que ser reconhecido como parte dos fatores do sistema literário como um todo.

Com respeito às interrelações e correlações que um sistema mantém com outros sistemas controlados por outras comunidades, apenas um conjunto de fenômenos operando em uma certa comunidade pode ser concebido como um sistema parte de um polissistema maior, que por sua vez é parte também de um outro polissistema maior, o da Cultura Total dessa comunidade. Sendo assim, o último pode ser concebido como componente de um outro mega-polissistema, que organiza e controla diversas comunidades. Essas unidades não podem ser consideradas nem claramente definidas nem finalizadas, suas fronteiras, e mesmo seus conteúdos, mudam o tempo todo, não apenas dentro dos sistemas, mas entre eles.

Even-Zohar ${ }^{115}$ aponta como um dos objetivos primordiais da Teoria Polissistêmica lidar com as condições específicas sob as quais uma literatura pode sofrer interferência de outra, acarretando a transferência de propriedades de um polissistema para outro. Sendo assim, da mesma maneira que a Teoria Polissistêmica considera que propriedades periféricas podem penetrar o centro de um sistema, uma vez que esse centro encontrese enfraquecido, ela também defende a entrada e influência de elementos e propriedades de um polissistema em outro, interferências intersistêmicas. Afirma também que as interferências, ao contrário do que comumente se acredita, ocorrem geralmente via periferias e que, quando esse processo é ignorado, não se encontra explicação para o surgimento de novos itens e funções no repertório. Para a Teoria Polissistêmica, todos os estratos da literatura são objetos de estudo indispensáveis para o entendimento do processo das transferências, tanto dentro de um sistema quanto entre

${ }^{115}$ EVEN-ZOHAR, 1990. 
Introdução

sistemas diferentes, e do porquê dessas transferências. Para proporcionar esse entendimento faz-se necessário, portanto, incluir estratos que são, geralmente, negligenciados pelos estudos literários como: textos semiliterários, literatura traduzida, literatura infantil, literatura popular, etc.

Finalmente, o autor trata de estabilidade e instabilidade dos sistemas e aponta que, por vezes, um sistema em que mudanças controladas ocorrem o tempo todo pode ser considerado um sistema mais estável do que um que não sofra mudanças e que possa vir a se petrificar ou colapsar. Sendo assim, a produção literária de escritoras negras e a existência de narrativas com meninas negras como protagonistas cria produtos no sistema literário que apresentam diferentes repertórios, subvertendo modelos originários de sistemas literários centrais, podendo funcionar como fator desestabilizador de sistemas literários que até há pouco não permitiam a existência desse tipo de narrativas.

\section{Crescer nas Margens - Narrativas de Formação Pós-Colonial}

Os quatro romances que compõem o corpus deste estudo apresentam a formação de meninas negras até a idade adulta, desestabilizando os romances de formação tradicionais e constituindo uma variedade pós-colonial do gênero, como descrita por José Santiago Fernández Vázquez ${ }^{116}$, em Reescrituras postcoloniales del Bildungsroman.

As características dessa variedade e a subversão da fórmula do Bildungsroman serão tratadas nesta seção, porém, faz-se importante ressaltar que a minha leitura dos romances como Bildungsromane póscoloniais, não pretende desconsiderar as limitações de algumas definições de pós-colonialismo que, por vezes, conforme explicitado anteriormente, excluem as experiências dissonantes das populações de terceiro mundo e, mais especificamente, das mulheres negras. $\mathrm{O}$ pós-colonialismo a que me refiro implica articulações com as especificidades de cada sociedade e diz

\footnotetext{
${ }^{116}$ VÁZQUEZ, José Santiago Fernández, Reescrituras postcoloniales del Bildungsroman, Editorial Verbum, Madrid, 2003.
} 
respeito ao período posterior ao fim do período colonial formal, não impedindo observar a existência de outros processos de colonização ou mesmo a repetição das estruturas coloniais em hierarquias internas estabelecidas em cada país em que se passam as narrativas. Considero também importante ressaltar que o modelo do Bildungsroman pós-colonial realiza uma apropriação do repertório dos antigos opressores, adaptando-o e distorcendo-o em proveito próprio. Para apoiar esta ideia, mostra-se muito adequado mencionar a comparação feita por Chmweizu et al entre o Bildungsroman pós-colonial e o piano, comentada por Vázquez ${ }^{117}$. Eles comparam o Bildungsroman pós-colonial e o piano, um instrumento que, apesar de ser invenção europeia, foi utilizado por músicos de diversas partes do mundo para interpretar outros tipos de melodias, com a modificação, inclusive, dos sistemas rítmicos para os quais havia inicialmente sido concebido.

Para que se possa prosseguir no entendimento da variação póscolonial do Bildungsroman faz-se fundamental levantar algumas das características principais do modelo tradicional conectado à ideologia colonialista. Um estudo anterior ${ }^{118}$ de Vázquez apresenta as características fundamentais desse gênero, e as descreverei a seguir com o intuito de demonstrar posteriormente as alterações realizadas pela variedade póscolonial.

A primeira característica do Bildungsroman tradicional é a existência de uma evolução por parte do protagonista (geralmente um menino ou um jovem). A evolução ocorre de acordo com certos princípios pedagógicos, como o respeito à liberdade e à autonomia do indivíduo, além da promoção de um desenvolvimento harmônico e ordenado. Nessa evolução, desempenham papel essencial as relações amorosas, que funcionam como via de integração social e assimilação dos valores dominantes. Também tem papel importante nessa evolução o deslocamento geográfico do protagonista, que se afasta do meio familiar para desenvolver uma personalidade independente.

\footnotetext{
${ }^{117}$ Id., 2003.

${ }^{118}$ VÁZQUEZ, 2002 apud VÁZQUEZ, 2003, p.11.
} 
Vázquez ${ }^{119}$ afirma também que para a aprendizagem chegar a bom termo é preciso que ela ocorra sob uma vertente dupla, explicada pelos estudiosos alemães como a oposição entre Ausbildung e Anbildung. O primeiro termo diz respeito ao desenvolvimento das capacidades inatas do protagonista, enquanto o segundo trata da necessidade de que o aperfeiçoamento individual seja complementado por um adestramento social. Para a consecução desse objetivo, o protagonista é tutelado por um ou mais personagens que exercem o papel de mentor, ocupando-se de garantir o bem estar material e espiritual do herói.

Do ponto de vista narrativo, há, normalmente, uma interação entre a voz adulta do narrador (em primeira ou terceira pessoa) e a voz imatura do protagonista. Por meio dessa interação, o leitor pode constatar que o processo de aprendizagem chegou a bom termo e observar que o protagonista rechaça seu passado rebelde, envergonhando-se dos erros cometidos. A voz do narrador mostra-se distanciada da perspectiva juvenil do herói, e essa perspectiva é desaprovada utilizando o recurso da ironia.

Outro importante traço do Bildungsroman, em sua forma tradicional, é a presença de uma estrutura linear e teleológica em que se observam quatro etapas principais, sendo a primeira a separação, em que o herói abandona o meio familiar, criando um enfrentamento com os adultos. A segunda é a iniciação ao mundo adulto, ligada ao aperfeiçoamento do personagem por meio de diversas experiências de vida. Em seguida, ocorre a escolha, quando o herói demonstra haver adquirido maturidade para enfrentar seu futuro e toma a decisão de integrar-se à sociedade adulta. $A$ última etapa é o retorno, que consiste na volta ao âmbito comunitário e na resolução do conflito inicial.

Vázquez $^{120}$ estabelece uma correspondência entre a progressão teleológica observada no Bildungsroman clássico e os sistemas historicistas que favoreceram o desenvolvimento do colonialismo europeu. $\mathrm{O}$ autor afirma que ao descrever a aprendizagem do herói em etapas sucessivas que parecem se contradizerem, mas que de fato se complementam, formando

\footnotetext{
${ }^{119}$ VÀZQUEZ, 2003.

${ }^{120}$ Id., 2003.
} 
um todo homogêneo, o Bildungsroman incorpora ao texto a visão dialética que Hegel e outros filósofos historicistas usaram para descrever o devir histórico. Por sua vez, a existência de um processo educativo, capaz de dar sentido a tudo o que acontece, conecta-se ao modelo teleológico proposto por essa escola filosófica que propugna a existência de uma racionalidade histórica universal.

O historicismo defende também a ideia de um progresso unitário, ao qual todas as nações devem se submeter, e essa ideia foi usada como pretexto para justificar a intervenção dos poderes coloniais em territórios não europeus. Tendo em mente esse progresso unitário a que todas as nações devem submeter-se, é possível traçar uma analogia entre a evolução pedagógica do protagonista do Bildungsroman e o projeto civilizador posto em prática nas colônias. Sendo assim, é possível afirmar que a relação mentor e Bildungsheld nos romances de formação clássicos reproduz a distinção kantiana entre os indivíduos que já alcançaram um grau de maturidade suficiente e aqueles que ainda permanecem em um estado de imaturidade e devem ser submetidos à tutela de outros seres humanos.

A própria mobilidade geográfica, que aparece frequentemente nesse tipo de Bildungsroman, pode ser relacionada com a necessidade colonial de formar sujeitos empreendedores e dispostos a viajar a territórios longínquos em busca de melhorias econômicas e profissionais, em conformidade com o capitalismo mercantil sobre o qual se baseou o colonialismo europeu. Além disso, a existência de um vínculo entre o ethos colonialista e a construção da subjetividade do Bildungsheld se manifesta na difusão dos valores burgueses do racionalismo, positivismo e individualismo que presidiram o processo de aculturação dos sujeitos colonizados.

A marginalização do fantástico, que é típica do romance realista ocidental, é parte, no Romance de Formação, de uma intenção mais ampla de ignorar outras formas de subjetividade e manter a ilusão de um eu unitário. Partindo desse pressuposto, o Bildungsroman apresenta uma relação com as ideias lacanianas que afirmam que a repressão da alteridade constitui o corolário do processo de construção do sujeito, sendo que a 
repressão da alteridade no Bildungsroman clássico ocorre, segundo $V_{\text {Vázquez }}{ }^{121}$, não apenas pela contenção do discurso fantástico, mas por outros procedimentos, como os esforços do Bildungsheld em controlar seus impulsos homoeróticos; a omissão da temática colonialista que é incorporada ao texto por referências encobertas; a eliminação de personagens que se opõem aos valores em torno dos quais deve gravitar a formação; e, de uma perspectiva formal, a intenção de limitar a interação das vozes do narrador e do protagonista, criando um relato coerente que evita a sensação da existência de uma divisão na mente do herói.

As características do Bildungsroman tradicional, acima descritas, apontam o gênero como pertencente a polissistemas culturais de sociedades centrais europeias, enquanto que no Bildungsroman pós-colonial, observase tanto uma influência dos polissistemas literários europeus quanto um desejo dos colonizados de realizar uma "descolonização mental"122,123. Essa descolonização pressupõe uma alteração dos padrões narrativos e ideológicos associados ao gênero literário, introduzindo inovações formais e temáticas em sua tradição para adaptar essa forma literária à realidade das ex-colônias e se opor a uma ideologia imperialista sedimentada em sua forma clássica. É preciso ter em mente, todavia, que os estudos realizados por Vázquez ${ }^{124}$ compreenderam a crítica de romances de formação póscoloniais com protagonistas exclusivamente masculinos, em romances escritos por homens, e que, sendo assim, outros elementos e estratégias poderão surgir advindos dos conflitos vivenciados pelas protagonistas negras apresentadas por escritoras mulheres das narrativas que constituem o foco desta pesquisa.

Dentre os traços fundamentais da variação pós-colonial do Bildungsroman apresentados por Vázquez ${ }^{125}$, o primeiro diz respeito à pretensão de superar a natureza individualista do modelo tradicional. Pretensão que leva ao estabelecimento de um paralelismo entre o processo

\footnotetext{
121 VÀZQUEZ, 2003.

122 Tradução minha.

${ }^{123}$ No original: "descolonización mental” (VÀZQUEZ, 2003, p. 115)

124 Id., 2003.

125 Id., 2003.
} 
de formação e a construção de uma identidade nacional. Parece-me, todavia, importante considerar que nos romances escritos por escritoras negras, o motivo da construção da identidade nacional pode não estar presente ou mesmo ser tratado de forma diversa, visto que as mulheres negras são frequentemente marginais a essa construção. O segundo traço, apontado pelo autor, trata das inovações quanto ao tema da viagem e aponta para o fato de que, com frequência, não há viagem de iniciação ou que as condições dramáticas em que ela ocorre servem para ressaltar a ausência de estímulo para o desenvolvimento das capacidades inatas do sujeito pós-colonial e o estado de alienação em que permanece o herói, no nosso caso a heroína, assim como sua falta de autonomia.

A iniciação romântica, terceiro evento característico, desempenha um papel menor no Bildungsroman pós-colonial do que aquele desempenhado no modelo tradicional do gênero. Atrações românticas não consumadas, pelo menos não explicitamente, relações platônicas, o não alcance da maturidade sexual ou mesmo dificuldades na aceitação da sua própria identidade sexual mostram-se comuns no Bildungsroman póscolonial. Em vários casos, a sexualidade do(a) protagonista transcende o âmbito do socialmente aceitável, sendo que sua incapacidade de estabelecer relações sancionadas pela comunidade denuncia a inexistência de um projeto social capaz de garantir a integração do herói/heroína, ao contrário do que ocorre no romance de formação tradicional, em que a iniciação romântica contribui para que o protagonista aceite a ordem social dominante.

Outra importante característica do Bildungsroman pós-colonial é a falta de mentores adequados que tutelem o desenvolvimento mental e afetivo do herói/heroína. Pode-se assim afirmar que uma das principais diferenças entre o Bildungsroman tradicional e o pós-colonial consiste na alteração da função exercida pelo mentor, que no Bildungsroman póscolonial é identificado com o poder (neo)colonialista. Na maioria desses romances, o mentor prioriza a defesa da ordem estabelecida em detrimento do bem estar do herói, podendo mesmo explorá-lo. A atuação negligente do 
Introdução

mentor pode invalidar o processo de formação do protagonista, favorecendo o surgimento de sentimentos de culpa e insegurança que dificultam sua entrada na sociedade adulta. As personagens que se preocupam de fato com o bem-estar do protagonista e cumprem, desse modo, a tarefa do mentor, são personagens que se afastam do papel de guardiães da ordem social e se convertem em empecilho para o triunfo da ideologia hegemônica. Pode-se concluir que, no Bildungsroman pós-colonial, existe uma incompatibilidade entre as duas funções normalmente exercidas pelo mentor (proteção do protagonista e salva-guarda da ordem social). Isso ocorre como consequência da natureza repressora e da falta de legitimidade dos valores sociais em que se pretende iniciar o protagonista.

A denúncia do caráter nocivo dos mecanismos de individuação promulgados pelas classes hegemônicas é também outro traço fundamental do Bildungsroman pós-colonial. Com o objetivo de promover essa denúncia, justifica-se que, de acordo com Vázquez ${ }^{126}$, o autor tome partido do protagonista na disputa com os guardiães da ordem social, utilizando para esse fim diversos meios, como: a crítica direta por parte de alguns personagens secundários e diversos procedimentos indiretos como, por exemplo, a reescritura dos estereótipos nacionalistas e o uso da ironia, não para censurar o herói mas sim, todos aqueles que abusem de sua situação indefesa.

O final dos romances de formação pós-coloniais também difere daquele dos romances tradicionais do gênero, distanciando-se do triunfalismo desses últimos e semeando dúvida quanto ao futuro do protagonista. Além disso, a ausência de provas do êxito do processo de formação, junto à alteração da estrutura linear e cronológica da narrativa, põe em questão a trama teleológica própria da variante tradicional, bombardeando assim a relação mantida pelo gênero com os sistemas historicistas e o progresso em geral.

${ }^{126}$ VÀZQUEZ, 2003. 
Em referência às características do Bildungsroman pós-colonial, Vázquez $^{127}$ ainda aponta para o fato de que, em oposição à subjetividade unificada e homogênea promovida pelo Bildungsroman clássico, os autores pós-coloniais optam por ressaltar o pertencimento do protagonista a diversos âmbitos culturais, enfatizando sua condição híbrida ou limítrofe, sendo que o questionamento do sujeito unitário pode se dar inclusive, no plano simbólico, por meio de algum tipo de mestiçagem.

Também é possível observar mudanças na estrutura típica do Bildungsroman tradicional, composta das etapas de separação, iniciação, escolha e retorno. Nos Bildungsromane pós-coloniais, a separação normalmente não se dá por rebeldia do protagonista, nem pela necessidade de desenvolver sua personalidade de modo independente. Ela é, de fato, imposta, seja por circunstâncias econômicas dramáticas seja pelo desejo dos pais de melhorar a condição de vida dos filhos, incitando-os a assimilar os modos de vida europeus e a renunciar a suas raízes culturais.

Com respeito às etapas da escolha e do retorno, também é possível observar algumas inovações. Obviamente, quando a separação não ocorre, a etapa do retorno também desaparece. Contudo, mesmo que ocorra a separação, o movimento de retorno pode ficar interdito ou ocorrer com imensa dificuldade. O momento da escolha, por sua vez, pode ser mantido em suspenso com o objetivo de enfatizar a falta de autonomia do protagonista frente ao mentor ou com o fim de declarar a primazia da comunidade sobre o indivíduo. Nesse quesito, a marginalidade das mulheres negras nas sociedades patriarcais parece acarretar certa independência dessa primazia.

Tendo refletido sobre 0 arcabouço teórico básico para 0 desenvolvimento desta pesquisa e tendo em mente a ideia inicialmente apresentada de que para lidar com a trajetória das meninas protagonistas dos romances em foco, Lucy $^{128}$, Ponciá Vicêncio ${ }^{129}$, Sophie Caco $^{130}$ e

\footnotetext{
127 Id., 2003.

${ }^{128}$ KINCAID, 2002.

${ }^{129}$ EVARISTO, 2003.

130 DANTICAT, 1998.
} 
Xuela $^{131}$, é preciso acompanhar as teorias apenas pela parte do caminho em que elas se mostrem adequadas, é imprescindível realizar um frequente trabalho de articulação, pois se mostra impossível que uma só teoria abranja a complexidade das posições em que atuam essas personagens, das relações estabelecidas por elas com as sociedades em que vivem e da especificidade de seus movimentos e de suas transformações. Passo agora, desse modo, a seguir com elas, acompanhando seu crescer, suas trajetórias e os caminhos que trilham, de meninas a mulheres.

${ }^{131}$ KINCAID, 1997. 


\section{Capítulo 1 Migrações Domésticas}

Ponciá Vicêncio, de Conceição Evaristo ${ }^{1}$ e The Autobiography of My Mother, de Jamaica Kincaid ${ }^{2}$, são narrativas cuja análise compõe o primeiro capítulo desta tese. As trajetórias de suas protagonistas apresentam movimentos internos aos limites de seus países de nascimento. Suas migrações são domésticas, mas as experiências vividas no processo acarretam profundas mudanças, o que permite não apenas compará-las entre si, como também às migrações transnacionais que ocorrem nos romances Lucy ${ }^{3}$ e Breath, Eyes, Memory foco do segundo capítulo deste trabalho.

\section{A Diáspora Doméstica de Ponciá Vicêncio}

A fortuna crítica disponível que trata do romance Ponciá Vicêncio, de Conceição Evaristo ${ }^{5}$, concentra-se, em geral, nas questões étnica e de gênero, na relação da narrativa com o gênero Romance de Formação, na memória individual e coletiva, incluindo também alguns estudos comparativos com textos de escritoras africanas e afro-americanas. Além disso, a maioria dos textos críticos referentes ao romance procura traçar uma tradição literária afro-brasileira e, mais especificamente, das escritoras negras brasileiras, inserindo Conceição Evaristo nessa tradição.

Um dos trabalhos que se inicia com o posicionamento da obra de Conceição Evaristo em uma tradição literária afro-brasileira é a dissertação Uma escrita em dupla face: A mulher negra em Ponciá Vicêncio, de

${ }^{1}$ EVARISTO, Conceição, 2003.

${ }^{2}$ KINCAID, 1997.

${ }^{3}$ KINCAID, 1997a.

4 DANTICAT, 1994.

${ }^{5}$ EVARISTO, op.cit. 
Conceição Evaristo, de Flávia Santos de Araújo ${ }^{6}$. A autora propõe um resgate das vozes de várias escritoras negras que foram silenciadas por séculos e o estabelecimento de uma releitura crítica da historiografia literária do Brasil. Araújo ${ }^{7}$ defende também a promoção de um diálogo entre as narrativas escritas às margens do que se convencionou como o cânone da literatura brasileira. Ao lidar com a questão identitária em Ponciá Vicêncio, Araújo $^{8}$ aponta a questão da memória coletiva, a importância da rememoração e a vinculação de Ponciá com o passado coletivo do povo negro da diáspora e com a "memória cultural dos africanos escravizados"9. Embora a memória coletiva e o aspecto historiográfico não sejam os pontos principais da presente análise, entender a diáspora africana e as conexões das experiências e trajetórias das protagonistas das narrativas aqui em foco implica em considerar o passado comum de escravidão a que seus antepassados foram submetidos e, nesse aspecto, guarda certa semelhança com parte do trabalho de Araújo ${ }^{10}$.

Aline Alves Arruda, por sua vez, é autora de diversos artigos que analisam a obra Ponciá Vicêncio sob variados aspectos. Em "A errância diaspórica como paródia da procura em Ponciá Vicêncio, de Conceição Evaristo e um Defeito de Cor, de Ana Maria Gonçalves"11, Arruda equipara Ponciá Vicêncio aos romances de formação tradicionais que mostram uma trajetória de desenvolvimento, em geral, de um protagonista branco e masculino.

Em "Ponciá Vicêncio, de Conceição Evaristo: Um Bildungsroman feminino e negro", Aline Alves Arruda ${ }^{12}$ desenvolve sua abordagem de

${ }^{6}$ ARAÚJO, F. S. de. Uma escrita em dupla face: A mulher negra em Ponciá Vicêncio, de Conceição Evaristo, 2007.

${ }^{7}$ Id., 2007.

${ }^{8}$ Id., 2007.

${ }^{9}$ Ibid., p. 96.

${ }^{10}$ ARAÚJO, 2007.

${ }^{11}$ ARRUDA, Aline Alves, A errância diaspórica como paródia da procura em Ponciá Vicêncio, de Conceição Evaristo e um Defeito de Cor, de Ana Maria Gonçalves. Anais do XII Seminário Nacional Mulher e Literatura e do III Seminário Internacional Mulher e Literatura Gênero, Identidade e Hibridismo Cultural, 2007a.

12 ARRUDA, Aline Alves, Ponciá Vicêncio, de Conceição Evaristo: um Bildungsroman feminino e negro, Literafro, Universidade Federal de Minas Gerais, Belo Horizonte, 2007b. 
Capítulo 1 Migrações Domésticas

Ponciá Vicêncio como Bildungsroman, categorizando-o como pertencente ao quinto tipo de romance de formação descrito por Bakhtin, o romance de formação realista, que tem como exemplo "Os anos de aprendizado de Wilhelm Meister", de Goethe. Esse tipo de romance, de acordo com Arruda $^{13}$, é "aquele em que a evolução do homem é indissolúvel da evolução histórica". No entanto, embora correta, essa categorização não aborda todas as questões colocadas pelo romance. A narrativa se enquadra muito mais na categoria de Bildungsroman pós-colonial, como descrito por Vásquez, ${ }^{14}$ apesar de ser ainda necessário considerar as especificidades desse tipo de narrativa quando protagonizada por uma mulher negra em uma ex-colônia, com uma sociedade racista e patriarcal.

Embora realize uma leitura de Ponciá Vicêncio como Bildungsroman realista, que se mostra um pouco restrita, Arruda ${ }^{15}$, corretamente, ressalta o pouco espaço ocupado pela mulher nas narrativas de formação tradicionais e critica a interrupção da formação das mulheres em virtude das "obrigações femininas"16. Em respeito a essa última questão, precisamos, todavia, considerar que nos primeiros romances de formação feminina, denominados Bildungsromane domésticos ${ }^{17}$, o que de fato ocorre não é a interrupção da formação das protagonistas pelas "obrigações femininas", visto que elas fazem parte do que constitui a formação tradicional da mulher. Não é, portanto, o caso de afirmar que as protagonistas não chegam à formação final como os protagonistas masculinos, como defende Arruda $^{18}$. O que ocorre é que a formação destinada aos protagonistas masculinos é diferente da que se destina às protagonistas femininas.

A trajetória da mulher nessa modalidade de romance de formação feminino deve levá-la ao casamento e ao desempenho das tarefas domésticas ligadas ao lar e à maternidade. Quando esse destino começa a

Disponível em: http://www.letras.ufmg.br/literafro/data1/autores/43/conceicaocritica02.pdf. Acesso em 14 de julho de 2014.

13 Ibid., p.02.

${ }^{14}$ VÁSQUEZ, 2003.

${ }^{15}$ ARRUDA, 2007b.

${ }^{16}$ ARRUDA, 2007b, p.02.

${ }^{17}$ KORNFELD, E., JACKSON, S, 1987.

${ }^{18}$ ARRUDA, 2007b. 
ser contestado, no sec. XIX, em geral, a protagonista enlouquece ou morre, no chamado Bildungsroman falhado ${ }^{19}$. No romance de formação póscolonial, por sua vez, embora as diferenças de gênero sejam mantidas, a subversão da fórmula tradicional pode trazer à baila trajetórias diversas e assim apresentar resultados diferentes, embora, nem sempre, de sucesso. Nessa variedade de trajetória, o questionamento do status quo é o que viabiliza verificar que "nossa cultura não é um monólito homogéneo [sic] (isto é masculina, classe média, heterossexual, branca e ocidental) que podemos ter presumido" 20 .

Além disso, em "A errância diaspórica como paródia da procura em Ponciá Vicêncio, de Conceição Evaristo e Um Defeito de Cor, de Ana Maria Gonçalves", Arruda ${ }^{21}$ considera que a migração interna de Ponciá pode ser vista como uma metáfora da diáspora. Observação que se mostra como valorosa contribuição e a qual também defendo. Em "Ponciá Vicêncio, de Conceição Evaristo: um Bildungsroman feminino e negro", a autora aponta a semelhança da viagem de Ponciá com as migrações transnacionais, comparação que também faz parte do presente estudo e considera seu processo migratório, mais uma vez, como uma metáfora da diáspora. Ressalto que as diferenças do meio rural para o urbano brasileiro, que possibilitam essa interpretação, são tão profundas que oferecem, de fato, um paralelo às novas diásporas transnacionais a que se sujeitaram os povos negros de ascendência africana, como a dos povos caribenhos para a Inglaterra, Estados Unidos e Canadá.

Quanto ao final da narrativa, cabe observar que considerá-la como um "final feliz", como o faz Arruda ${ }^{22}$, é extremamente preocupante no que diz respeito às questões étnicas e de gênero da sociedade brasileira. A autora alega a existência de um "final feliz", tendo como base o retorno de Ponciá a seu lugar de origem e "seu reencontro com a arte e com sua história

\footnotetext{
${ }^{19}$ PRATT, 1974, 1981.

${ }^{20}$ HUTCHEON, 1991 apud ARRUDA, 2007b, p. 03.

${ }^{21}$ ARRUDA, 2007a.

${ }^{22}$ ARRUDA,2007a, p.93.
} 
Capítulo 1 Migrações Domésticas

individual e coletiva" ${ }^{23}$. Todavia, o fim do romance não apresenta esse reencontro, apenas o retorno de Ponciá, seu irmão e sua mãe para a roça. 0 final deixa em aberto se essa volta será positiva ou não para Ponciá e não descreve sua retomada da produção artística de fato, visto que Ponciá realiza um "imaginário ato de fazer" ${ }^{24}$ sua arte. A própria decisão de voltar à roça não conta efetivamente com a participação da protagonista e a tomada de consciência no que concerne a coletividade se dá por parte de seu irmão Luandi: "Compreendera que sua vida, um grão de areia lá no fundo do rio, só tomaria corpo, só engrandeceria, se se tornasse material argamassa de outras vidas. 25 .

Ponciá é apontada como herdeira da história sofrida de seu povo e símbolo do sofrimento que, vivo, deverá despertar o desejo, nos outros membros de seu grupo, de criar um outro destino. Esse papel de mártir que deverá servir de inspiração não me parece condizente ao que se convém chamar de "final feliz". Além disso, dentro de uma perspectiva de gênero, apontar como destino final da personagem ser cuidada pelos familiares após uma ação motivada pelo delírio, pois Ponciá caminha até a estação, com a intenção de ir para o rio, e prossegue esculpindo no ar como se fora o barro, não apresenta uma solução emancipadora ou libertadora para a personagem mulher. Ao contrário, o destino de Ponciá encontra-se à mercê da decisão do personagem masculino, que também passa por um processo de formação, muito mais bem sucedido que o seu, visto que Luandi estabelece um lugar de relativo poder dentro da sociedade urbana, tornando-se soldado, e toma sua decisão de voltar ao meio rural como forma de trabalhar junto à família e à comunidade para o progresso de uma coletividade, final típico dos Bildungsromane pós-coloniais com personagens masculinos.

Ponciá Vicêncio, primeiro romance publicado de Conceição Evaristo $^{26}$, apropria-se do Bildungsroman, gênero originário de um

\footnotetext{
${ }^{23}$ ARRUDA, 2007a, p.93.

${ }^{24}$ EVARISTO, 2003, p. 131.

${ }^{25}$ Ibid., p. 131.

${ }^{26}$ EVARISTO, 2003.
} 
Capítulo 1 Migrações Domésticas

polissistema central europeu, comumente usado para expressar a experiência dos membros de sociedades colonizadoras, subvertendo esse gênero para apresentar em romance de um polissistema literário periférico a experiência de uma personagem feminina e negra. Personagem essa que não só vive em sociedade periférica, mas às margens dessa sociedade, ou seja, à margem da margem. O romance inicia-se com uma narrativa em media-res, sendo que uma narradora heterodiegética relembra a infância feliz de Ponciá, tempo em que ela afirma gostar de ser mulher. O relato descreve sua relação familiar de modo positivo, tendo a mulher nesse espaço uma posição atuante. A narradora retoma o momento presente em que, no entanto, se passa a observar os efeitos funestos que a perda dessa relação acarretou. Sua trajetória, que a levou à cidade grande, também a conduziu ao estado de isolamento e apatia em que se encontra. A opção por uma narração heterodiegética decorre do fato de o romance estabelecer a trajetória de formação, não apenas de Ponciá, mas também de seu irmão Luandi. Além disso, a situação de Ponciá, de desconexão com o mundo, pede por um Outro que transcenda seu estado de torpor e assim seja possível contar sua história. Esse Outro, maior, é conceito originário do estágio do espelho de Lacan, fase essencial do desenvolvimento infantil para o processo de individuação do $\mathrm{eu}^{27}$. É um conceito também apropriado pelos estudos pós-coloniais e apresentado como verbete em Key concepts of post-colonial studies ${ }^{28}$ para explicar o processo de dominação na colonização e de rebaixamento do outro colonizado. Nesse processo, o colonizador é identificado com o Outro maior, a quem são atribuídas virtudes diversas; e o colonizado, como um outro menor, construído pelo discurso do Outro. No caso específico de Ponciá Vicêncio, esse Outro maior mostra-se necessário para a narração de sua história. Essa narração por outrem cria, todavia, um distanciamento maior da subjetividade da personagem que é ainda mais enfatizado pela opacidade causada pelo estado de depressão e confusão mental em que se encontra.

\footnotetext{
${ }^{27}$ LACAN, 1998.

${ }^{28}$ ASHCROFT et al, 1998.
} 
Em Ponciá Vicêncio, a narrativa em retrospecto retorna não só ao passado da personagem, mas a um passado anterior, que descreve a vida tanto de seu avô e de seu pai quanto da comunidade negra de que são originários, escravos e ex-escravos da família Vicêncio. Essa retomada situa a história de Ponciá no contexto histórico maior da diáspora africana. A diáspora, palavra que vem do grego e significa "dispersar," é definida por Ashcroft et. al. ${ }^{29}$ como o movimento voluntário ou forçado de povos a partir de suas terras natais para novas regiões, sendo considerado um fato central nos processos de colonização. O próprio colonialismo mostra-se como um movimento diaspórico radical que envolve uma dispersão temporária ou permanente e o estabelecimento de milhões de europeus por diversas regiões do mundo.

Muitas dessas regiões foram desenvolvidas historicamente como colônias agrícolas que deveriam fornecer produtos alimentícios para a população da metrópole. Sendo assim, ainda de acordo com Ashcroft et. al. ${ }^{30}$, demandavam uma larga escala de mão de obra que foi suprida, principalmente nas Américas, embora não exclusivamente, pela escravidão (sistema que acarretou uma diáspora forçada dos povos africanos para as Américas a partir da costa oeste do continente).

Para lidar com as consequências do sistema escravocrata e da manutenção da opressão aos ex-escravos observadas na narrativa, mesmo após a abolição da escravatura, mostra-se útil o conceito de opressão e as suas cinco faces, como apresentadas pela teórica feminista americana, Iris Young $^{31}$. Segundo a autora, a opressão se apresenta de cinco maneiras que são assim definidas: a exploração, que é relacionada à transferência dos resultados do trabalho de um grupo social para o lucro de outro; a marginalização, que diz respeito à expulsão da participação útil na sociedade; a carência de poder, que se refere à impossibilidade de participar de tomadas de decisões na sociedade, mesmo de modo indireto; o imperialismo cultural, em que os traços dominantes da sociedade tornam

${ }^{29}$ Id., 1998.

${ }^{30}$ ASHCROFT et al, 1998.

${ }^{31}$ YOUNG, Iris, 1990. 
Capítulo 1 Migrações Domésticas

invisível a perspectiva particular de um grupo ao mesmo tempo em que o estereotipam e assinalam como o outro; e a violência, vista como tal quando o contexto social que rodeia as ações violentas não só as possibilita como as considera aceitáveis, sendo existentes como prática social.

No romance, os efeitos da diáspora e do sistema escravocrata no Brasil, com suas consequentes relações de opressão, mostram-se presentes na vida da comunidade rural de Vila Vicêncio e nas trajetórias de vida dos membros da família de Ponciá. Quando da abolição da escravatura, por exemplo, a comunidade se alegrou com a notícia de que o Coronel Vicêncio daria terra para todos, o que Ihes proporcionaria "a verdadeira alforria"32. Havia a condição de que continuassem a trabalhar nas terras do Coronel. Mesmo assim, descreve-se imensa esperança com a propriedade da terra, a possibilidade de terem casas, suas, fora da fazenda e seu próprio plantio. As terras e os papéis de comprovação da posse até são entregues para os exescravos, todavia, o Coronel os engana pedindo de volta os documentos, alegando que os manteria em segurança. Desse modo, os membros da comunidade perdem a prova da posse da terra e são mantidos todos "sob o jugo de um poder que, como Deus, se fazia eterno."33. Continuam, desse modo, na situação anterior de despossuídos e dependentes da relação de opressão senhor de terras/escravos, apenas disfarçada pela relação capitalista de exploração.

A tragédia de Vô Vicêncio exemplifica, por sua vez, o desespero de um homem que vê vários de seus filhos, nascidos após a lei do ventre livre, serem vendidos, como muitos outros filhos de escravos na mesma situação. O desamparo e a descrença despertam nele um sentimento de revolta, expresso em um gesto que a narradora descreve como entre a coragem e a covardia. O avô de Ponciá, de posse de uma foice, mata a mulher e tenta se matar. O pai de Ponciá só não é morto porque corre para buscar ajuda, mas assiste ao assassinato de sua mãe. Sendo impedido de completar seu intuito, o Velho Vicêncio é forçado a viver com a consciência do crime cometido e enlouquece. Torna-se um estorvo para os senhores, visto que

\footnotetext{
32 EVARISTO, 2003, p. 47.

${ }^{33}$ Ibid., p. 48.
} 
Capítulo 1 Migrações Domésticas

não mais pode produzir, vivendo de sobras e da caridade dos seus. Quando o coronel Vicêncio tenta reaver os papéis das terras do avô de Ponciá, este leva o papel preso entre os dentes, como um cachorro talvez, e, com a mão boa, rasga-os raivosamente na presença do coronel. Essas duas medidas extremas de Vô Vicêncio podem ser vistas de certo modo como atos de resistência à opressão sofrida, contudo não oferecem consequências positivas para os descendentes dele, visto que são obrigados a lidar com a morte trágica dos parentes e ainda permanecem em situação semelhante a de todos os negros que devolveram os documentos da terra, sem sua posse. O avô de Ponciá segue, desse modo, rindo e chorando ao mesmo tempo, até que chegue o dia de sua morte, e é motivo de vergonha e ódio de seu filho, o pai de Ponciá.

Esse pai, por sua vez, sendo filho de ex-escravos, cresceu na fazenda e levou a mesma vida dos pais, sendo obrigado, em criança, a ser pajem do filho do coronel, o "sinhô-moço" e sofrer, além da exploração de um trabalho não remunerado, humilhações e violências, como a descrita na passagem abaixo:

Um dia o coronelzinho exigiu que ele abrisse a boca, pois queria mijar dentro. O pajem abriu. A urina do outro caía escorrendo quente por sua goela e pelo canto de sua boca. Sinhô-moço ria, ria. Ele chorava e não sabia o que mais the salgava a boca, se o gosto da urina ou se o sabor de suas lágrimas. $^{34}$

Quando criança, todavia, ainda demonstrava revolta e chegou a questionar o pai quanto a situação em que viviam: "Se eram livres, por que continuavam ali?"35. Não obteve resposta, o pai riu e chorou ao mesmo tempo. Ao rememorar a relação com o pai, o pai de Ponciá descreve duas fases diversas. Na primeira, sentia respeito, medo e algo que ele não tinha certeza se era amor. Na segunda, no entanto, após o assassinato da mãe, os sentimentos não deixam dúvida e o menino passa a sentir pavor, ódio e muita vergonha. Com o passar dos anos, a revolta parece ceder à força da opressão e ele se acomoda à mesma vida de trabalho nas terras do Coronel

\footnotetext{
${ }^{34}$ EVARISTO, 2003, p. 14.

${ }^{35}$ Ibid., p. 14.
} 
que tiveram seus antepassados, mantendo sua raiva direcionada apenas ao pai. Pode-se inferir que essa raiva se refere tanto ao assassinato da mãe, acontecimento suficiente para gerar um trauma familiar irremediável, como também ao fato de que a loucura do pai impede que o filho sequer pense em deixar o lugar, preso a uma obrigação filial. Embora odeie o pai, é na casa dele que o velho vive até o fim de seus dias. Desse modo, o pai de Ponciá permanece na fazenda dos Vicêncio até que morre durante a labuta da roça.

É após a morte do pai, mais um dos seus explorado até o fim nas terras dos brancos, que Ponciá decide migrar. A viagem de Ponciá é parte da estrutura do romance de formação pós-colonial em que se desenvolve a narrativa. Ponciá, como muitos imigrantes brasileiros, parte de sua terra natal para buscar melhores condições de vida, à revelia da mãe que não compreende o desejo da filha. Sua partida é repleta de sonhos e de esperança. Sua decisão é descrita como algo forte e repentino e suas motivações refletem a falta de fé em qualquer possibilidade de melhoria no meio rural onde vive: "Cansada da luta insana, sem glória a que todos se entregavam para amanhecer cada dia mais pobres, enquanto alguns conseguiam enriquecer-se a todo o dia." ${ }^{36}$

Considero que sua viagem assemelha-se a uma nova diáspora, visto que a origem da protagonista é conectada à primeira diáspora dos escravos africanos trazidos à força para as Américas e que o seu processo individual faz parte de um movimento maior que foi o êxodo rural brasileiro na década em referência. Como diferença da diáspora imposta aos seus antepassados, encontra-se a voluntariedade da viagem da personagem, embora motivada pelas dificuldades socioeconômicas apresentadas no meio rural em que vive, além de consistir em uma migração intranacional. São as diferenças brutais entre a realidade do interior e das grandes cidades do Brasil que possibilitam estabelecer um paralelo entre a migração interna de Ponciá e a que ocorre de um continente para outro, como a que se observa nos

${ }^{36}$ EVARISTO, 2003, p. 32. 
Capítulo 1 Migrações Domésticas

romances Breath, Eyes, Memory ${ }^{37}$ e Lucy ${ }^{38}$ de que tratarei no próximo capítulo.

A esperança de Ponciá na migração é percebida na crença de que na cidade, diferentemente do campo, ela poderia traçar seus próprios caminhos, criar outra vida. A moça carrega consigo também uma visão otimista das relações de gênero, baseada na união de seus pais e na sua infância na comunidade dos ex-escravos. Na primeira etapa de sua vida, portanto, a visão de Ponciá de ser mulher era positiva, como ela mesma observa: "O pai era forte, o irmão, quase um homem, a mãe mandava e eles obedeciam. Era tão bom ser mulher! Um dia ela teria um homem que, mesmo brigando, haveria de fazer tudo o que ela quisesse e teria filhos também." ${ }^{39}$ Essa visão muda quando Ponciá vai para a cidade, pois ela passa a considerar que talvez não fosse tão ruim ser homem.

É preciso ter em mente que a mulher em comunidades negras ocupa uma posição de mais prestígio e vale lembrar que nas religiões animistas, o poder é dividido entre os membros de um casal divino, ao invés de se concentrar nas mãos de um Deus único patriarcal. Sendo assim, a família de Ponciá apresenta uma divisão de poder entre gêneros mais equilibrada, enquanto que na cidade ela se depara com uma sociedade patriarcal. Quando migra, embora conhecendo diversos casos de fracasso, Ponciá acredita que obterá sucesso na cidade grande.

No seu processo de formação, Ponciá possui tanto mentores positivos, como aqueles presentes nos romances de formação tradicionais, que a protegem e preparam para a vida, quanto mentores ambíguos ou negativos, típicos da variante pós-colonial do gênero. A mãe é uma das mentoras positivas, que lhe transmite o saber da arte do barro e lhe fornece uma imagem positiva de mulher. Nêngua Kainda também é uma mentora positiva que representa a tradição e a religiosidade africana em que se baseia a comunidade de onde Ponciá é originária. Essa formação, no entanto, é adequada apenas para a vivência no meio rural e não se mostra

\footnotetext{
${ }^{37}$ DANTICAT, 1994.

38 KINCAID, 2002.

${ }^{39}$ EVARISTO, 2003, p. 24.
} 
útil quando Ponciá parte para a cidade grande. A própria mãe de Ponciá analisa a diferença entre o saber necessário para a roça e para a vida na cidade:

O importante na roça era conhecer as fases da lua, o tempo de plantio e de colheita, o tempo das águas e das secas. A garrafada para o mau [sic] da pele [...] O saber que se precisa na roça difere em tudo do da cidade ${ }^{40}$.

Pensando que Ponciá poderia ter outras opções e trilhar um caminho diferente, a mãe autoriza a menina a aprender a ler quando os missionários chegam à vila para alfabetizar a população local.

Em sua partida, de fato, grande parte da esperança de Ponciá está depositada na sua capacidade de leitura. A menina aprende a ler com esses missionários que funcionam como mentores inadequados, típicos dos romances de formação pós-colonial. Membros da igreja católica tradicional e defensores da ordem estabelecida, historicamente posicionados ao lado do poder colonial e, em seguida, dos grandes proprietários de terra brasileiros, eles ensinam letras e sílabas, mas vão embora quando a menina começa a formar palavras. Ainda conectada à sua origem, Ponciá mantém sua autonomia e continua sozinha o aprendizado da leitura.

Desse modo, Ponciá avança um pouco mais do que seus antepassados, mas é possível estabelecer um paralelo entre seu aprendizado interrompido pela debandada dos missionários e o de seu pai, quando o sinhô-moço se pergunta para que serviria a leitura para um negro. Mesmo assim, talvez por não entender que havia galgado apenas um pequeno degrau, é essa capacidade de leitura que, em retrospecto, Ponciá aponta como fonte de sua fé nas conquistas futuras que obteria indo para a cidade. A narradora relata uma época em que Ponciá lia todas as notícias de jornal e até mesmo as memorizava. Pode-se inferir que Ponciá é uma analfabeta funcional, visto que embora leia as histórias, não apresenta nenhuma atitude crítica em relação a elas, nenhum vestígio de interpretação. Um dia, desiludida com o recurso da leitura que não the trouxe os avanços sonhados no meio urbano, ela resolve juntar todos os jornais que havia

${ }^{40}$ EVARISTO, 2003, p. 25. 
guardado e fazer uma fogueira. Nesse dia reflete sobre a esperança que construíra na leitura e a decepção com a realidade na cidade: "De que valia ter aprendido a ler? No tempo em que vivia na roça, pensava que, quando viesse para a cidade, a leitura lhe abriria meio mundo ou até o mundo inteiro. Agora nada lhe interessava mais nas notícias[...]"11.

Embora, não forneça as ferramentas adequadas para a vida de Ponciá no meio urbano, a existência da mãe como mentora positiva em um romance de formação é digna de nota como inovação nos romances do gênero. A mãe de Ponciá mostra-se como exemplo de amor, força e independência no meio rural. Ela é vista por Ponciá como a chefe da família. Quando o pai retornava da roça era ela (a mãe) "quem determinava o que o homem faria em casa naqueles dias. O que deveria fazer quando regressasse lá para as terras dos brancos. $O$ que deveria dizer para eles. $O$ que deveria trazer da próxima vez que voltasse para casa [...]"42. É a visão da relação de gênero em seu meio familial que faz com que Ponciá tenha uma visão positiva do que é ser mulher. Essa visão, todavia, esfacela-se com sua vida na cidade grande em que é reservado à mulher, especialmente à mulher negra, pobre e sem instrução, o lugar da subalternidade.

Ponciá, embora sabendo que o irmão havia partido para a mesma cidade e que sua mãe, com a partida do irmão, também abandonara a vila, decide retornar à Vila Vicêncio na esperança de conseguir informações quanto ao paradeiro dos dois. Esse primeiro retorno se dá de modo voluntário, em um momento em que Ponciá ainda dispõe de autonomia. Ela havia juntado dinheiro por anos e conseguido finalmente comprar um quartinho na periferia e, para que a conquista fizesse sentido, ela queria localizar o irmão e a mãe e trazê-los para viver com ela.

Em sua volta ao povoado, Ponciá observa a manutenção de "um pulso de ferro a segurar o tempo. Uma soberana mão que eternizava uma condição antiga." ${ }^{43}$ A manutenção da população negra em condição de escravidão é percebida por Ponciá, ao mesmo tempo que ela sente sua

\footnotetext{
${ }^{41}$ EVARISTO, 2003, p. 93.

42 lbid., p. 24.

43 lbid., p. 48.
} 
existência individual como dependente de um coletivo: "A casa era sua enquanto os outros existiam" ${ }^{44}$. Sem sua família no povoado, Ponciá não se sente inteira. Ela decide voltar à cidade, mas, sem os seus ali, também aumentam seus vazios e ausências. De todo modo, Nêngua Kainda, a líder espiritual do povoado, a alerta para o fato de que qualquer que seja a sua decisão, ir ou ficar, a herança de Vô Vicêncio se manifestará um dia. Sendo assim, embora Ponciá não tenha consciência de qual seja sua herança, é possível entender que a loucura chegaria à Ponciá, quer ela tivesse ficado no campo, quer tivesse retornado à cidade.

Quando Ponciá volta ao meio urbano desse primeiro retorno ao povoado, a viagem lhe parece mais longa e dolorosa que a primeira porque já não há mais grandes sonhos e ilusões. Ponciá volta para uma realidade dura e já familiar, retorna ao emprego conhecido e encontra o homem por quem se enamorara antes da viagem e que era operário em uma construção civil ao lado da casa em que ela trabalhava. Esse homem é quem se tornará seu companheiro.

A relação entre Ponciá e seu homem, no entanto, estabelece-se como uma relação apenas corporal, o que não é suficiente para ela. Em um trecho do romance, a narradora fala da superficialidade da relação e da frustração da protagonista: "Nem quando ela o conheceu, nem quando ela e ele sorriam e se amavam ainda, Ponciá conseguiu abrir para ele algo além do que seu corpo-pernas. Às vezes, tentava, mas ele sempre calado, silencioso, morno." ${ }^{45}$ Mesmo o nível corporal da relação não é satisfatório para Ponciá, pois:

Muitas vezes nem o prazer era repartido. Depois então, ela sozinha, relembrava com o pensamento e com as mãos o prazer que tinha tido um dia, quando cheia de medo e desespero se tocou para se certificar que, após a passagem por debaixo do angorô, ainda continuava menina. ${ }^{46}$

A relação do casal sofre uma escalada que passa da dificuldade de comunicação entre os dois para a violência de gênero, sendo que Ponciá

\footnotetext{
${ }^{44}$ EVARISTO, 2003, p. 58.

${ }^{45}$ Ibid., p. 43.

${ }^{46}$ Ibid., p. 43.
} 
Capítulo 1 Migrações Domésticas

apanha diversas vezes do companheiro, que não entende o isolamento e a depressão como doença da mulher. A narrativa procura justificar a violência a que o marido recorre no lidar com a parceira pelo contexto de opressão e violência que ele mesmo sofre. Todavia, apesar de se poder tentar compreender o contexto em que o marido de Ponciá vive, nada justifica a violência de gênero, a não ser a permissão que the é dada pela sociedade patriarcal. A narradora descreve o sofrimento do homem que sente falta da Ponciá que conhecera, trabalhadora, companheira, com quem saía junto para a labuta diária. A reação do companheiro à apatia de Ponciá é, com frequência, enchê-la de socos e pontapés.

Em suas reflexões, Ponciá se culpa pela violência que sofre e conclui que "pelo menos para os homens que ela conhecera, a vida era tão difícil quanto para mulher." 47 A reflexão de Ponciá se dá dentro dos limites impostos pelo pensamento patriarcal e consiste em uma repetição que termina por favorecer a opressão das mulheres por elas próprias, tendo em mente que observados os exemplos no texto, exceto pela relação mais equilibrada que mantém os pais de Ponciá, percebe-se que o avô de Ponciá decide o destino de sua avó, assassinando-a; a namorada de Luandi é assassinada pelo cafetão; e a própria Ponciá, que passa pelo mesmo tipo de privação que o marido, é a única que apanha no casal. Do ponto de vista de uma abordagem feminista, é preciso realizar uma leitura crítica da visão da protagonista de sua situação. Ponciá, a partir de seu lugar de fala, repete o discurso patriarcal sem crítica e protege o agressor, aceitando sua própria opressão a partir de uma atitude de compreensão da opressão porque passa o homem negro.

Ressalto aqui a definição dos papéis da mulher na mitologia social das sociedades patriarcais. De acordo com Mussel ${ }^{48}$, ela ocorre primariamente em três formas: como esposa, como mãe e como dona de casa, sendo esses os papéis que definem as esferas de atuação apropriadas às mulheres, os limites do seu universo e o conteúdo pertinente a esse universo. As mulheres que não tiverem as três áreas de definição

\footnotetext{
47 Ibid., p. 54.

${ }^{48}$ Mussel, 1981 (in FLEENOR, 1983).
} 
disponibilizadas a elas se encontrarão em um vácuo social parcial, não podendo desempenhar algumas das atividades esperadas. No caso da ocorrência desse vácuo, ou seja, de uma mulher não poder ou não ter a oportunidade de desempenhar uma dessas funções, ela precisa se redefinir. O trabalho, quando presente, surge como uma nova camada de exigências que tem que ser conciliada com os demais papéis.

É lidando, em geral, com os três papéis acima mencionados, mais a camada de demandas adicionais acarretadas pela jornada de trabalho, que as mulheres negras têm que enfrentar seus papéis sociais. Embora se possa questionar que a rua e o trabalho de baixa remuneração sempre tenham feito parte da mitologia social atribuída às mulheres negras, de modo diverso ao que ocorreu com as mulheres brancas, que apenas recentemente conquistaram espaço no trabalho e que eram mantidas na "proteção" do ambiente doméstico, todos esses papéis estão presentes na trajetória de Ponciá, tanto com suas demandas quanto com as eventuais necessidades de sublimação.

A protagonista para de trabalhar quando adoece, ficando só com os papéis de esposa e dona de casa. Com a perda dos filhos e o passar do tempo, mesmo as tarefas tradicionais, como o cuidado com a casa, passam a ser negligenciadas, em razão do estado de desânimo do qual se apercebe a própria protagonista: "Toda noite ela contemplava o desleixo da casa, a falta de asseio que lhe incomodava tanto, mas faltava-lhe coragem para mudar aquela ambiência." 49 marido também reflete sobre a mudança de comportamento da companheira:

Ele sentia saudades da outra Ponciá Vicêncio, aquela que ele conhecera um dia. E se perguntava, sem entender, o que estava acontecendo com sua mulher. Ela que antes era feito uma formiga laboriosa resolvendo tudo. Ela que muitas vezes saía junto com ele na labuta diária do fogão, da limpeza, das trouxas de roupa nas casas das patroas. O que estava acontecendo com Ponciá Vicêncio ${ }^{50}$

\footnotetext{
${ }^{49}$ Evaristo, 2003, p. 22.

50 lbid., p. 54.
} 
Capítulo 1 Migrações Domésticas

Nem o marido, nem Ponciá entendem o que está acontecendo com ela. Seria necessário o acesso a um sistema de saúde que a assistisse, identificasse o processo de depressão por que ela passa, e a tratasse adequadamente para que algo mudasse. Porém, como se pode observar também com as sucessivas perdas dos filhos de Ponciá, o atendimento de saúde para a personagem, quando ela tem acesso, é incipiente, podendo ser considerado mesmo irresponsável por parte dos médicos. As perdas dos filhos, em parte responsáveis pelo estado depressivo de Ponciá, se repetem inicialmente, nos primeiros cinco partos, sem explicação, pois ela dá a luz em casa com o auxílio de uma parteira.

Os dois últimos partos, entretanto, ocorrem em hospital, onde os médicos explicam que a perda ocorre "por causa de uma complicação no sangue" ${ }^{51}$, podendo subentender-se que Ponciá sofre de Eritroblastose Fetal $^{52}$. A doença poderia ser facilmente evitada na gestação seguinte, caso houvesse acompanhamento médico, mas isso não ocorre e depois da perda do sétimo filho, Ponciá não mais engravida, porque ela e o companheiro deixam de relacionar-se sexualmente.

Sem entender sua situação, vendo-se desamparada, a protagonista não consegue superar a impossibilidade de exercer seu papel de mãe, deixando também de exercer os outros papéis impostos sem encontrar alternativa. Além disso, sua atividade artística, que poderia talvez ajudá-la a transcender esses papéis, não pode ser realizada na cidade. Sendo assim, ela permanece imobilizada até que o delírio a movimente e a família a socorra.

O final do romance, com o segundo retorno de Ponciá ao meio rural, aproxima-se também das características, já descritas no capítulo introdutório desta tese, do Bildungsroman pós-colonial. Não há triunfalismo, nem um progresso que leve a um sucesso absoluto, como ocorre com frequência nos romances de formação tradicionais. Toda a trajetória de Ponciá é

${ }^{51}$ Ibid., p. 52

52 Doença do sangue causada pela incompatibilidade do Rh do sangue materno (negativo) e do feto, positivo. Quando isso acontece, durante a gestação, a mulher produz anticorpos anti-Rh para tentar destruir o agente Rh do feto, que é considerado como intruso pelo seu corpo. 
apresentada de forma catastrófica, visto que com seu afastamento da comunidade rural e do meio familial, ela se recolhe, tornando-se uma personagem opaca. Todo seu processo de formação é narrado por outrem, devido ao estado de isolamento psíquico a que ela terminaria por chegar. Seu encontro com o irmão ocorre porque, em um delírio, ela desce o morro em direção à estação de trem com a intenção de chegar ao rio onde encontraria o barro para moldar suas esculturas. O retorno anunciado à sua terra é uma tentativa de recuperação da identidade de Ponciá, mas não é promovido por ela mesma, nem é sua decisão. A família se reencontra no final do romance e decide retornar para o interior. Luandi, irmão de Ponciá, cuja trajetória é narrada também como um Bildungsroman, embora consiga obter certo sucesso na cidade e passar por um processo de formação (tendo como mentor positivo o Soldado Nestor), entende que seu sucesso não vale nada sem que sua família e comunidade estejam bem. Apesar de ter realizado o sonho de ser soldado, o irmão de Ponciá resolve abandonar a farda e retornar com ela e a mãe para o meio rural. Para tomar essa decisão, reflete:

Compreendera que sua vida, um grão de areia lá no fundo do rio, só tomaria corpo, só engrandeceria, se se tornasse matéria argamassa de outras vidas. Descobria também que não bastava saber ler e assinar o nome. Da leitura era preciso tirar outra sabedoria. Era preciso autorizar o texto da própria vida, assim como era preciso construir a história dos seus. ${ }^{53}$

Para compreender o destino de Ponciá é preciso ter em mente a condição prévia da protagonista, uma mulher negra, pouco letrada e de uma comunidade rural em que a relativa igualdade entre os membros de sua família reduz a possibilidade de preconceito e opressão dentro dos limites dessa comunidade, e que, ao chegar à cidade, torna-se portadora de diversas marcas negativas em um sistema patriarcal e branco para o qual não estava preparada. Nesse novo meio, passa a ser vista como negra,

${ }^{53}$ EVARISTO, 2003, p. 131. 
semianalfabeta e mulher, com toda a carga de opressão que incorrem essas posições no meio urbano da sociedade brasileira.

Quando Luandi vê a irmã na estação, em seu primeiro dia de soldado, Ponciá "ia e vinha, num caminhar sem nexo, quase em círculo[...]" $]^{\prime 54}$. Mesmo ao retornar para sua comunidade, a protagonista permanece em estado de loucura, moldando esculturas de barro imaginárias. Indica-se que a etapa do retorno será concretizada. Todavia, como já ressaltado anteriormente, o processo é imposto, devido ao insucesso do seu processo de formação na cidade, tendo como base a crença de uma identidade comunitária maior e um caminho de volta à memória, à ancestralidade e à natureza, que poderão ajudar a restituir a identidade de Ponciá.

Entretanto, se considerarmos a ida de Ponciá Vicêncio para a cidade grande com uma metáfora de uma segunda diáspora, podemos também comparar sua volta à comunidade rural ao retorno dos sujeitos diaspóricos da Inglaterra para seus países de origem de que fala Stuart Hall ${ }^{55}$, citando uma série de entrevistas realizadas por Mary Chamberlain com imigrantes barbadianos. Segundo Hall, os entrevistados mencionam a dificuldade ao retornarem a suas sociedades de origem em se reconectarem a elas: "Muitos sentem que a 'terra' tornou-se irreconhecível. Em contrapartida, são vistos como se os elos naturais e espontâneos que antes possuíam tivessem sido interrompidos por suas experiências diaspóricas." ${ }^{56}$ De modo similar, não se sabe até que ponto a experiência da migração modificou Ponciá. Portanto, não há garantia de que o retorno às origens proporcionado por sua família, por si, consistirá na solução para sua reintegração a uma vida equilibrada em sociedade.

Ponciá é mulher, é negra, é pobre e é louca, esta sendo a herança manifesta de seu avô. É possível estabelecer uma relação de causalidade entre esses atributos. E são eles que a tornam protagonista de um

\footnotetext{
${ }^{54}$ Ibid., p. 126.

${ }^{55}$ HALL, Stuart, 2003.

${ }^{56}$ Ibid., 2003.
} 
Bildungsroman pós-colonial, levando às adaptações no gênero para abarcar sua experiência, que é diferente tanto da de um protagonista masculino quanto da de uma protagonista feminina branca. Sendo assim, a trajetória de Ponciá subverte o gênero para contar a história dessa personagem, uma menina (depois mulher) negra, de uma sociedade periférica e patriarcal, que, de outro modo, não poderia ter sido narrada. Na variação pós-colonial do Bildungsroman, portanto, cria-se um espaço para que histórias, lugares e personagens, invisíveis nos modelos tradicionais, tornem-se enfim visíveis. Um espaço em que se possa acompanhar suas trajetórias, seus movimentos, e em que se exponham os conflitos das sociedades em que vivem.

Como não há tratamento crítico do contexto de opressão em que Ponciá vive, até por sua condição de isolamento que impossibilita que ela mesma possa produzir mudança, os conflitos são apresentados na narrativa como uma denúncia das relações sociais de opressão no Brasil. Desse modo, embora não haja proposta ou atitude de mudança na narrativa, a exposição dessa opressão tem como objetivo provocar reflexão quanto à situação dos trabalhadores rurais, dos proletários, dos negros e das mulheres brasileiras. 


\section{The Autobiography of my Mother - $O$ revide dos derrotados}

The Autobiography of my Mother ${ }^{57}$ narra a vida de Xuela Claudette Richardson desde seu nascimento, momento da morte de sua mãe. O título contém em si a contradição presente em toda a narrativa. A autobiografia da mãe que já morreu é, na realidade, a história de Xuela e da presença/ausência de sua mãe, da falta do amor dessa mãe e de suas consequências na vida dessa menina e no seu crescer. A narrativa também trata da relação do povo caribenho colonizado com suas origens, com o colonizador, e com o próprio processo de colonização. Nesta análise de The Autobiography of my Mother, pretendo observar tanto a falta de amor familial, quanto a falta que permeia o processo de colonização, verificando se elas promovem e facilitam a movimentação de Xuela na ilha de Dominica e de que modo o fazem.

Joanne Gass ${ }^{58}$, em Jamaica Kincaid and Caribbean Double Crossings, estabelece uma comparação entre The Autobiography of my Mother, de Jamaica Kincaid, Jane Eyre, de Charlotte Brontë, e Wide Sargasso Sea, de Jean Rhys. Em sua comparação, Gass ${ }^{59}$ chama atenção para o fato de que as experiências das protagonistas dos três romances guardam, todas, uma conexão com o processo de colonização britânica das ilhas do Caribe. Entretanto, as vivências divergem tanto devido à sua localização quanto à postura perante a colonização. Jane Eyre, uma moça branca, inglesa, recebe as informações sobre Bertha Rochester por intermédio do Sr. Rochester, e esta visão, que lhe chega, é carregada das cores colonialistas da visão da mulher mestiça como um outro degenerado, sexualizado e infantilizado.

Em Wide Sargasso Sea, por sua vez, Gass ${ }^{60}$ observa que Jean Rhys dá voz à Bertha Rochester, antes de ser levada à força à Inglaterra por seu marido e trancafiada no sótão. Antoinette (segundo Rhys, o verdadeiro

\footnotetext{
${ }^{57}$ KINCAID, 1997.

${ }^{58}$ GASS, Joanne, 2010 (in LANG-PERALTA, 2010).

${ }^{59}$ Ibid., 2010.

60 Ibid., 2010.
} 
Capítulo 1 Migrações Domésticas

nome de Bertha Rochester) ao mesmo tempo em que é chamada, pela população negra da Jamaica, de barata branca, é vista pelos colonizadores como uma "branca-negra" ("white nigger"). Embora Jean Rhis dê voz a Antoinette, a voz da personagem é de alguém que busca a aceitação do colonizador, que vê a assimilação como o caminho para a felicidade e que, de acordo com Gass ${ }^{61}$, enlouquece quando traída pelo marido que também se recusa a identificá-la como verdadeiramente inglesa, vendo-a sempre como um outro sexualizado, a quem deseja domar, ao mesmo tempo em que lhe tem temor.

Em The Autobiography of my Mother, por outro lado, a narradora autodiegética, também mestiça, como ressaltado por $\mathrm{Gass}^{62}$, relata sua experiência de um ponto de vista crítico em relação à experiência colonial e coloca-se em oposição constante ao colonizador. A quebra, por Xuela quando criança, do prato de Ma Eunice, que retratava uma paisagem bucólica inglesa com a palavra "paraíso" escrita embaixo, já fornece um indício simbólico de como a personagem se comportará em referência ao colonialismo britânico por toda a narrativa. Mesmo o casamento de Xuela com Philip, um homem inglês, ocorre como uma forma de inverter a experiência colonizadora britânica, como uma espécie de vingança.

Xuela utiliza-se de diversos meios para isolar, fragilizar e dominar seu marido. Após casarem-se, mudam-se para uma casa na região das montanhas, território dos índios caribes, onde Philip não consegue falar a língua e Xuela tem que servir de intérprete para que ele possa se comunicar. Essa interpretação é desempenhada como forma de dominação, visto que ela admite traduzir e omitir o que quer e como quer, por vezes enganando-o. Xuela boicota também o trabalho de catalogação de espécimes do marido, um certo tipo de dominação colonial do meio que ele tenta exercer e que ela rejeita. Ela também recusa qualquer ligação, subordinada ou mesmo de igual para a igual, com Philip e concentra seus esforços em manter o marido dominado, de certo modo colonizado. Sabendo do desejo de Philip de ouvir sua voz, por exemplo, Xuela recusa-se a falar com ele por longos períodos.

\footnotetext{
${ }^{61}$ GASS, 2010 (in LANG-PERALTA, 2010).

62 Ibid., 2010.
} 
Além disso, observo que a vida sexual do casal é estabelecida desde o princípio como uma questão de poder. Na primeira relação sexual do casal, Xuela já manipula as posições de modo que, não fosse a sua narração dos fatos, em que repete várias vezes a frase "Eu fiz com que ele..." ${ }^{\text {33,64 }}$, a situação poderia ser entendida como uma repetição da violenta dominação colonial do corpo da mulher negra, as mãos de Xuela amarradas pelo cinto, seu rosto virado de lado, o corpo masculino que a toma pelas costas. É a narração de Xuela que demonstra a inversão desses papéis e seu revide por meio da sexualidade:

...ergui minhas mãos no ar, e com meu rosto virado de lado encostei o peito contra a parede. Eu fiz com que ele ficasse em pé atrás de mim, eu fiz com que ele deitasse sobre mim, meu rosto abaixo do dele; eu fiz com que ele deitasse em cima de mim, minhas costas embaixo do seu peito; eu fiz com que ele deitasse por trás de mim e colocasse sua mão na minha boca... ${ }^{65,66}$

A análise de Gass, ${ }^{67}$ que compara os três romances acima citados, apresenta também a percepção dessa autora com relação à personagem de Xuela como aquela que repete a lista de violações e de malfeitos que resultaram na aniquilação de um povo, os caribes, de quem Xuela em parte descende. Concordo com a autora quando aponta que a forma da protagonista de reagir a essa história de violações que se perpetuam até o presente é através de um processo de renegação. Acrescento ainda que esse processo de renegação é percebido inclusive na linguagem utilizada no romance, com inúmeros exemplos de sentenças proferidas pela narradora autodiegética na negativa. Essa constatação da negação pela linguagem será tratada em detalhes mais à frente.

\footnotetext{
63 "I made him..." (KINCAID, 1997, p. 154)

64 Tradução Minha.

65 "... I raised my hands in the air, and with my face turned sideways I placed my chest against a wall. I made him stand behind me, I made him lie on top of me, my face beneath his; I made him lie on top of me, my back beneath his chest; I made him lie in back of me and place his hand in my mouth..." (Id. Ibid., p. 154)

66 Tradução Minha.

67 GASS, 2010 (in LANG-PERALTA, 2010).
} 
Capítulo 1 Migrações Domésticas

Discordo de Gass $^{68}$, apenas, quando declara que essa denúncia de Xuela dá voz ao povo de sua mãe, e que este seja o papel de Xuela, o de porta voz dos caribes. Defendo que Xuela, mestiça tanto dos caribes, aniquilados, dos negros africanos derrotados, mas sobreviventes, e do branco colonizador, visto que seu avô por parte de pai era um escocês, escolhe o lado desses dominados, tanto caribes quanto negros, e embora traga à tona uma outra história desses derrotados e aniquilados, não lhe é possível dar voz a esses últimos. Eles podem ser reconhecidos dentro do processo histórico, mas sua voz se perdeu, como perdeu-se a mãe de Xuela, morta no seu nascimento e de quem ela só vê, em sonhos, os calcanhares.

A morte da mãe a priva do contato com a herança que ela valoriza, a caribe, enquanto que a herança à qual ela tem acesso, a colonizadora (visto ser esta a valorizada por seu pai), é consistentemente recusada. Ela também não reivindica sua herança africana, em parte por que ela vem misturada com a herança colonizadora recusada, na medida que alguns negros, como seu pai, procuram uma assimilação. No entanto, como Xuela sempre escolhe o lado do oprimido, suas simpatias, enquanto narradora autodiegética, ainda são direcionadas a personagens negros oprimidos. Observo que não há, no romance, identificação de nenhum outro personagem que seja de origem caribe, que não Xuela e sua falecida mãe, o que ressalta o isolamento da narradora e o aniquilamento do povo de que descendem ela e a mãe.

A trajetória de Xuela é repleta de negações, que vão da falta de amor com que é recebida no mundo pelo pai, que a abandona aos cuidados da lavadeira de suas roupas, a uma falta de amor mais ampla, que diz respeito à destruição da auto-estima e da confiança, tanto no relacionamento entre pessoas do mesmo gênero, no caso, mulheres, quanto nas relações dos povos colonizados. As faltas geralmente se acumulam e incluem também questões étnico-raciais que contribuem para um nível de opressão superposto no romance.

${ }^{68}$ GASS, 2010 (in LANG-PERALTA, 2010). 
As negações, ressaltadas acima, fornecem já no primeiro capítulo o tom da narrativa, uma falta inicial de amor, de cuidado, percebida pela menina Xuela como conectada a uma história maior e a opção por uma renegação de tudo o que vem dessa história maior como uma estratégia de sobrevivência, em princípio, e de resistência conforme a protagonista vai crescendo. Como exemplo dessas negações na linguagem, cito a forma como Xuela descreve suas primeiras relações na infância, com o pai e com Ma Eunice: “... ele não sabia cuidar de mim sozinho, ou como lavar suas roupas sozinho, eu sei." ${ }^{69}$; sobre Ma Eunice, "Ela não era parente dele ou de minha mãe;"”70; sobre a recusa de deixar-se amamentar pela lavadeira, “...na minha boca o sabor era amargo e eu não o bebia."71; "Ma Eunice não era desumana"72 73 , "mas isso não quer dizer que fosse gentil com seus próprios filhos."74 (grifos meus). Outros exemplos podem ser encontrados, mas como não é o propósito deste trabalho fazer um levantamento exaustivo desses recursos de negação na narrativa, apenas ressaltar a importância deles em compor o ambiente de falta, de negação e de resistência de Xuela, menciono um último exemplo que aponta para a ambientação do romance, para a compreensão do clima dessa ilha resultante de um processo de colonização em que a menina percebe a impossibilidade do amor como herança:

Nunca cheguei a amar essa mulher com quem meu pai me deixou, essa mulher que não era desumana comigo mas que não podia ser gentil porque não sabia como sê-lo - e talvez eu não a tenha amado porque eu, também, não sabia como. ${ }^{75},{ }^{76}$

69 "... he did not know how to take care of me by himself, or how to clean his own clothes himself, I know." (KINCAID, 1997, p. 4)

70 "She was not a relative of his or of my mother's;" (Ibid., p. 5)

71 "... in my mouth it tasted sour and I would not drink it." (Ibid., p. 5)

72 "Ma Eunice was not unkind" (Ibid., p. 5)

73 Aqui optou-se por traduzir unkind, usualmente traduzido por rude, grosseira, por desumana, com o prefixo "des" de negação, para manter a dupla negação observada no texto original em "was not" e "unkind".

74 "... but this is not to say she was kind to her own children." (Ibid., p. 5)

${ }^{75}$ I never grew to love this woman my father left me with, this woman who was not unkind to me but who could not be kind because she did not know how - and perhaps I could not love her because I, too, did not know how." (Ibid., pp. 5, 6)

${ }^{76}$ Grifos meus. 
Capítulo 1 Migrações Domésticas

Esse recurso é largamente usado, e em média, dez expressões de negação podem ser encontradas em cada página do romance. Em uma análise estilística, esse recurso indica tanto ausência quanto negação, os dois elementos fundamentais da trajetória de Xuela.

Em "Caribbean Impossibility: The Lack of Jamaica Kincaid", em Jamaica Kincaid and Caribbean Double Crossings ${ }^{77}$, Thomas W. Sheehan discorre sobre a falta, que se observa como tema de muitas obras de Jamaica Kincaid, e compara essa falta com a que a autora, segundo ele, expressa em diversas entrevistas. Embora a presente análise não pretenda conectar a narrativa ficcional de The Autobiography of my Mother ${ }^{78} \mathrm{com}$ a vivência pessoal de Jamaica Kincaid, o que, a meu ver, pode resultar em inúmeras suposições sem maior validade acadêmica, é possível trazer à baila, a partir da análise de Sheehan, algumas questões pertinentes à análise, caminhando com esse autor pela parte do caminho que trata das negativas, da recusa de Xuela e de todo seu movimento impulsionado pelas faltas. Sheehan ${ }^{79}$ afirma que Xuela se constitui como indivíduo por suas recusas. Ao mesmo tempo que rejeita o pai, ela acolhe a falta de sua mãe. É, paradoxalmente, a presença dessa falta, dessa ausência maternal que serve de eixo condutor para toda a vida da personagem. Xuela não ama porque, na ausência de sua mãe e na presente ausência de seu pai, não encontra amor. Essa falta de amor e de apreciação é expandida para a experiência do colonizado na ilha de Dominica. Como resultado do processo de escravidão, de violência e dominação a que foram submetidos, fica impossível o estabelecimento de uma relação de amor entre os "derrotados", como Xuela se refere à população local, e os colonizadores vitoriosos. Concordo com Sheehan, quando declara que a protagonista toma a falta da mãe como um antiprincípio, sendo que essa falta a leva a ser também falta para todos com quem se relaciona. Sheehan afirma também que é apenas nessa falta que Xuela pode se preservar e que a falta da mãe, na narrativa, é também a falta de um povo, de uma nação com a qual identificar-se.

\footnotetext{
${ }^{77}$ SHEEHAN, 2010 (in LANG-PERALTA, 2010).

${ }^{78}$ KINCAID, 1997.

${ }^{79}$ SHEEHAN, op. cit.
} 
Xuela é híbrida, no sentido expresso por Bhabha ${ }^{80}$ que afirma o hibridismo como uma "reversão estratégica do processo de dominação pela recusa (ou seja, a produção de identidades discriminatórias que asseguram a identidade "pura" e original da autoridade)" 81 e também como uma "reavaliação do pressuposto da identidade colonial pela repetição de efeitos de identidade discriminatórios"82. Ele expõe a deformação e o deslocamento inerentes a todos os espaços de discriminação e dominação. Mais ainda, o hibridismo para Bhabha ${ }^{83}$ não fornece uma terceira posição em que se possa perceber uma homogeneidade, mas uma terceira posição que é local de conflitos.

Bhabha $^{84}$, discordando de Fanon, afirma que a mímica do colonizador realizada pelo colonizado consiste em um ato de resistência. Eu, por outro lado, entendo a mímica como uma estratégia de sobrevivência dentro do sistema colonial, mas não necessariamente de resistência, a não ser que realizada de maneira crítica. Na narrativa em questão, o pai de Xuela encontra-se alinhado com essa estratégia da mímica e, embora enriqueça, não utiliza seu enriquecimento para alterar a sociedade colonial e sim para, como assimilado, repetir o mesmo padrão de opressão contra o povo colonizado. Um exemplo desse comportamento do pai de Xuela é observado quando ele, sendo a maior autoridade governamental da cidade de Mahaut, fica encarregado pelo governo colonial de distribuir gratuitamente diversas coisas, entre as quais materiais de construção, para a população local se reerguer, após terem sido acometidos por um tornado de proporções catastróficas. A narradora autodiegética afirma que o pai distribuía um pouco das coisas de maneira gratuita apenas para não causar suspeita ou escândalo, mas vendia o resto. Ela ressalta a crueldade do pai,

\footnotetext{
${ }^{80}$ BHABHA, 2010.

81 lbid., p.162.

82 Ibid., p. 162.

${ }^{83}$ BHABHA, op. cit.

${ }^{84}$ BHABHA, op. cit.
} 
Capítulo 1 Migrações Domésticas

afirmando que "quanto mais a pessoa tinha dificuldade em pagar, quanto mais necessitada ela era, mais ele cobrava." ${ }^{\circ 5}$

A opção de Xuela mostra-se portanto mais alinhada, nesse aspecto, com Fanon, que afirma, de acordo com Bhabha ${ }^{86}$, que a opção psíquica é a de "virar branco ou desaparecer". Xuela como híbrida poderia apegar-se à sua origem parcialmente branca e assimilar-se, aceitando as vantajosas condições do opressor. Ela identifica essa opção, entretanto, como sendo a do pai, que é definido por Xuela como o resultado de um encontro de um homem escocês com o povo africano, e que opta por identificar-se com os vitoriosos dessa relação. A narradora autodiegética ressalta que o tom de pele do pai fazia com que ele parecesse mais com os vitoriosos, escoceses, mas ressalta que essa não teria sido a razão dele, e explica sua escolha: "Meu pai recusou as complicações dos dizimados; ele escolheu a facilidade do vitorioso." ${ }^{87}$ Mais ainda: "E assim como em meu pai existia ao mesmo tempo o vitorioso e o dizimado, o perpetrante e a vítima, ele escolheu, de modo algum surpreendentemente, o manto daquele, sempre daquele;" ${ }^{88}$

Desde muito cedo, por outro lado, Xuela, embora também mestiça e híbrida, recusa totalmente a identidade do vitorioso e assume sua identidade junto aos derrotados vivos, os de origem africana, e aos dizimados, caribes como sua mãe. Essa aliança com o lado mais fraco se dá sempre, mesmo quando ela sofre preconceito na escola, quando professora e alunos a veem como inferior por identificarem-na como membro da população original da ilha, a que havia sido eliminada. A menina reflete:

Eu era do povo africano, mas não exclusivamente. Minha mãe era uma mulher caribe, e quando eles olhavam para mim isso era o que eles viam: $O$ povo caribe havia sido derrotado e então exterminado, jogado fora como ervas

\footnotetext{
85 "the more a person was unable to pay, the more they were in need, the more he charged them." (KINCAID, 1997, p.188)

${ }^{86}$ BHABHA, 2010, p.174.

87 "My father rejected the complications of the vanquished; he chose the ease of the victor. (KINCAID, 1997, p.186)

88 "And so as in my father there existed at once victor and vanquished, perpetrator and victim, he chose, not at all surprisingly, the mantle of the former, always the former;" (Ibid., p. 192)
} 
Capítulo 1 Migrações Domésticas

daninhas em um jardim; o povo africano tinha sido derrotado, mas tinha sobrevivido. ${ }^{89}$

Essa hierarquia na derrota faz com que em vez de esses dois grupos oprimidos, derrotados, unirem-se, um deles opte pela opressão e discriminação do outro. A protagonista percebe que poderia se safar dessa situação, reivindicando sua identidade africana, mas ela conscientemente não o faz. Xuela opta sempre por negar uma aliança com o opressor: "Quando olhavam para mim, só viam o povo caribe. Eles estavam errados mas eu não disse isso a eles."

Apesar de mostrar-se aliada aos derrotados, a protagonista não se conforma meramente com essa posição e é tanto na sua visão crítica da realidade que a circunda, quanto na atuação de sua sexualidade, que Xuela circunscreve seu poder. Ela reconhece seus próprios desejos e os atende, primordialmente, antes de qualquer coisa. Masturba-se com frequência, em locais não socialmente aceitos, e atua em suas relações sexuais sempre em papel de dominação, de controle. É na relação com Philip, o médico inglês com quem se casa, que o controle típico de suas relações se assemelha a um revide do colonizado ao colonizador. É nessa relação que o derrotado se torna vitorioso e a derrrota se torna vingança, conforme indica Sheehan ${ }^{91}$.

A narrativa de Xuela, assim como a de Ponciá Vicêncio ${ }^{92}$ apropria-se do modelo do romance de formação tradicional, originário de um polissistema sociosemiótico europeu, subvertendo as estruturas tradicionais desse gênero para relatar a experiência do colonizado, do dominado. Mais ainda, The Autobiography of my Mother ${ }^{93}$ utiliza-se também do repertório do Gótico, gênero pertencente a um sistema periférico britânico, do século XVIII, que foi até considerado pela crítica como um subgênero, comprovando que as transferências e interferências entre diferentes sistemas

\footnotetext{
89 "I was of the African people, but not exclusively. My mother was a Carib Woman, and when they looked at me this is what they saw: The Carib people had been defeated and then exterminated, thrown away like the weeds in a garden; the African people had been defeated but had survived. " (Ibid., pp. 15, 16)

90 "When they looked at me, they saw only the Carib people. They were wrong but I did not tell them so."(Id. Ibid., p.16)

${ }^{91}$ SHEEHAN, 2010 (in LANG-PERALTA, 2010).

${ }^{92}$ EVARISTO, 2003.

${ }^{93}$ KINCAID, 1997.
} 
Capítulo 1 Migrações Domésticas

sociosemióticos ocorrem, como propõe a teoria polissistêmica de EvenZohar $^{94}$, tanto em sistemas de um só polissistema sincrônico, como diacronicamente entre sistemas de polissistemas diversos.

O Gótico interferiu, e ainda interfere, em obras de seu próprio polissistema, o da Literatura inglesa, tanto do século XVIII quanto de hoje; interferindo também em outros polissistemas, de outras culturas e outros tempos, como nas obras neogóticas americanas; nos filmes hollywoodianos de vampiros, fantasmas e lobisomens; em animações como Scooby-doo, A Noiva Cadáver e Coraline, baseado no romance homônimo de Neil Gaiman. O Gótico também encontra-se presente em romances pós-coloniais contemporâneos que relatam a experiência do oprimido, como o já mencionado Wide Sargasso Sea, de Jean Rhys, publicado pela primeira vez em 1966, e o romance The Autobiography of My Mother ${ }^{95}$, ora em foco, representando os horrores vivenciados na experiência de colonização e a herança traumática desse processo. Embora seja um gênero com alto grau de coesão entre seus elementos estruturais, o que dificultou sua absorção em outros sistemas literários, o Gótico foi retomado após a Primeira Grande Guerra como uma forma de expressar os horrores do conflito, cuja escala assombrou os contemporâneos. Por essa razão, quando escritores começaram a escrever sobre a experiência colonial, o repertório gótico já se encontrava novamente disponível para concorrer na representação da situação de extrema despossessão dos povos colonizados.

Diversos exemplos de elementos do Gótico podem ser observados em The Autobiography of my Mother ${ }^{96}$. O sobrenatural que provoca medo encontra-se em episódios como o do macaco, que propositalmente ataca Xuela, podendo ser considerado como uma Jablesse ${ }^{97}$, figura folclórica e demoníaca que pode tomar forma de animais; a entidade feminina que a menina e seus colegas vêem dentro do rio e sobre a qual falarei em detalhes

\footnotetext{
${ }^{94}$ EVEN-ZOHAR, 1990.

${ }^{95}$ KINCAID, 1997.

96 Id., 1997.

${ }^{97}$ As características da Jablesse encontram-se descritas em BESSON, Gérard. Folklore and Legends of Trinidad and Tobago. Port of Spain, Trinidad and Tobago, Paria Publishing Company Limited, $2^{a}$ edição, 1994.
} 
mais adiante; os sons de espíritos e criaturas sobrenaturais que a protagonista consegue ouvir durante a noite; os sonhos de Xuela sobre sua mãe, a travessia que ela realiza de modo sobrenatural, contornando toda a ilha; a personalidade tirânica e ameaçadora de seu pai que se assemelha a um vilão gótico, entre outros.

Além desses exemplos, presente em toda a narrativa, está o Obeah como atividade religiosa de origem africana que, de acordo com Lizabeth Paravisini-Gebert, no capítulo "Colonial and Post Colonial Gothic: The Caribbean" "98, de The Cambridge Companion to Gothic Fiction, é a tradição presente nas Índias Ocidentais de língua inglesa mais frequentemente utilizada nos romances góticos britânicos, sendo fonte tanto de estranhas práticas mágicas, como de fervor e violência revolucionários. O Obeah é um termo que designa, conforme explica Paravisini-Gebert ${ }^{99}$, um conjunto de crenças baseadas na espiritualidade e na percepção do sobrenatural, envolvendo aspectos de feitiçaria, mágica, e também de cura. Os feitiços do Obeah podem ser usados tanto para o bem quanto para o mal, servindo para fins de autoproteção, proteção de propriedade e de entes queridos; para trazer sorte no amor e nos negócios; como também para prejudicar e ferir inimigos.

No romance em foco, há duas situações específicas em que se pode perceber a presença do Obeah. A primeira diz respeito à tentativa da madrasta de Xuela de matá-la com um colar enfeitiçado. Xuela coloca o colar em um cachorro pertencente à madrasta, que morre em poucos dias. Outra situação refere-se à inusitada doença que acomete o meio irmão de Xuela e o estranho verme que sai de sua perna no momento de sua morte, como se lá estivesse a mando de alguém apenas para cumprir essa missão.

Embora observem-se diversos elementos góticos que demonstram os horrores do processo de colonização, a narradora autodiegética também apresenta inúmeras outras reflexões sobre a opressão do sistema colonial, como a escravidão e a dificuldade do colonizado, do derrotado, de enxergarse fora do sistema do colonizador. Uma das passagens mais fortes a esse

\footnotetext{
${ }^{98}$ PARAVISINI-GEBERT, 2007 (in HOGLE, 2007).

${ }^{99}$ PARAVISINI-GEBERT, op. cit.
} 
Capítulo 1 Migrações Domésticas

respeito questiona o papel da Igreja como instrumento mantenedor da dominação colonial. Xuela informa que, na ilha em que vive, o ir e vir da igreja tem praticamente poder de decreto e significa também uma nova derrota. Ela se pergunta: "... o que teria acontecido com todas as vidas dos conquistados se eles não tivessem passado a acreditar nos deuses do povo que os havia conquistado?" 100

Conforme mencionado anteriormente, The Autobiography of my Mother, assim como Ponciá Vicêncio ${ }^{101}$, configura-se em uma narrativa de formação pós-colonial, no entanto, de modo diverso ao que ocorre com Ponciá, o desenvolvimento de Xuela ocorre sem mentores. Tendo perdido a mãe no seu nascimento, Xuela resiste à falta de amor inerente ao ambiente pós-colonial e patriarcal em que vive e recusa todo e qualquer mentor ( $\mathrm{Ma}$ Eunice, a madrasta, a professora, Mme LaBatte) que aparece em seu caminho. A narrativa apresenta a trajetória de crescimento dessa menina que se torna sua própria mentora.

Após a morte de sua mãe, Xuela é entregue, pelo pai, como um pacote, aos cuidados de Ma Eunice, junto a um outro pacote das roupas dele para lavar. Xuela imagina que o pai deve ter dado instruções de prioridade quanto aos cuidados de um dos pacotes sobre o outro, mas sendo o pai um homem extremamente vaidoso, ela não pode dizer, ao certo, qual dos dois teria maior importância. O pai retorna, de quinze em quinze dias, para buscar suas roupas e ver a menina. No entanto, ela afirma que nessas visitas ele nunca a toca, nem olha nos olhos dela. Desde o princípio, observa-se, portanto, que a relação com o pai é marcada pela alienação e pela falta de amor.

Ma Eunice, por sua vez, é a primeira mentora possível de Xuela, mas essa relação fica impossibilitada pela herança colonial recebida pela mulher, que é, de acordo com a narradora autodiegética, a única herança possível, a brutalidade. Ma Eunice é incapaz de amar, pois todas as suas

100 " ... what would the outcome have been of all the lives of the conquered if they had not come to believe in the gods of the people who had conquered them? " (KINCAID, 1997, p.133)

${ }^{101}$ EVARISTO, 2003. 
Capítulo 1 Migrações Domésticas

referências, de acordo com a narradora autodiegética, são referências de tirania, exploração e violência. Sendo assim, a menina rejeita Ma Eunice como mentora desde tenra idade, cuspindo o leite que sentia amargo em sua boca e mordendo a mão de Ma Eunice quando ela tenta alimentá-la.

Em Writing Memory, Writing Back to the Mother, J. Brooks Bouson ${ }^{102}$ ressalta como em The Autobiography of my Mother há um enfoque na transmissão da herança colonial para as relações parentais, além de demonstrar o impacto que o colonialismo tem nas famílias e, em particular, no desenvolvimento das crianças. O castigo que Ma Eunice aplica em Xuela quando esta quebra o prato de porcelana com a paisagem britânica representando o paraíso é exemplo dessa relação entre colonização e tirania parental. Ma Eunice, tendo internalizado a relação desequilibrada de poder entre colonizador e colonizado, repete o mesmo padrão na punição da criança desobediente e teimosa, que torna-se sua vítima.

Xuela é forçada a ficar, em um local em que batia sol o dia inteiro, ajoelhada sobre pedras, com as mãos erguidas acima da cabeça e segurando duas pesadas pedras até decidir pedir desculpas. Ela se recusa a pedir desculpas e Ma Eunice passa então o dia proferindo diversas ofensas tanto à mãe quanto ao pai da menina. A narrativa conecta esse abuso da figura materna substituta ao abuso colonial em relação ao sujeito colonizado, sendo descrito pela narradora autodiegética como um castigo que remete, de todos os modos, "à relação entre captor e cativo, senhor e escravo, com seu tema de grande e pequeno, poderoso e impotente, forte e fraco..." 103

Vítima desse abuso parental ligado à experiência colonial, como acima descrito, Xuela repete o abuso com as únicas criaturas sobre as quais ela, como criança, pode exercer domínio, os três jabutis que ela encontra enquanto está de castigo pela quebra do prato. Primeiro, ela procura destinar o amor que não recebe a essas criaturas, mas sem possuir exemplo

\footnotetext{
102 BOUSON, 2005.

103 "... the relationship between captor and captive, master and slave, with its motif of the big and the small, the powerful and the powerless, the strong and the weak..." (KINCAID, 1997, p. 10).
} 
Capítulo 1 Migrações Domésticas

de amor, apenas de autoritarismo e dominação, a menina aprisiona os jabutis e, por eles não estarem disponíveis a ela sempre que queria, tampa o espaço de suas carapaças de onde saiam as cabeças com argila, como punição. Esquecendo-os por um tempo, reencontra-os mortos.

É possível entender este episódio como relacionado à decisão de Xuela na vida adulta de não ter filhos. Xuela não recebe amor na infância, não aprende a amar, e desde muito cedo percebe que essa falta de amor inicial impedirá que ela também ame. Para não correr o risco de repetir a tirania e a crueldade contra os inocentes que experimenta e observa no seu meio, a narradora autodiegética opta por jamais trazer filhos ao mundo. Embora a relação de Xuela e Ma Eunice não seja uma relação de mentora/bildungsheld, a narradora autodiegética é capaz de entender as limitações de Ma Eunice, em retrospecto, e sentir gratidão pelos cuidados que lhe foram dispensados por ela quando pequena.

A segunda potencial mentora de Xuela é a professora da primeira escola que a menina frequenta. Entretanto, a professora "do povo africano"104, como descreve a narradora autodiegética, lidava com sua própria identidade como uma fonte de isolamento e auto-desprezo e tinha o desespero como uma bengala, sobre a qual se apoiava com frequência. Esse desprezo por si mesma é exatamente o que ela esperava passar aos seus alunos.

A narradora autodiegética descreve o ambiente escolar como um ambiente sem amor e aponta para a complexidade das relações étnicas e discriminatórias na Dominica, demonstrando que era tratada com desprezo, pela professora e colegas, porque era vista por eles como pertencente ao povo caribe que havia sido, além de derrotado como o povo africano, aniquilado. À inteligência de Xuela, sua rápida capacidade de aprendizado e excelente memória, a professora responde com uma acusação de possessão, justificada por ela pela ascendência caribe de Xuela.

A entrada de Xuela para a escola e a relação com sua professora e os alunos constituem um momento importante da narrativa, visto que ali sua

104 "of the African people" (Ibid., p.15). 
posição como narradora confiável é posta em dúvida. A narradora autodiegética repete, durante todo o romance, que não se importa, por exemplo, com a falta de atenção do pai ou com o castigo de Ma Eunice; que não tem medo. Quando chega à escola, afirma:

Eu não estava com medo, porque minha mãe já havia morrido e isso é a única coisa de que uma criança realmente tem medo... e eu já havia vivido todos aqueles anos com Ma Eunice, uma mulher que não era minha mãe e que não podia me amar, e sem meu pai, nunca sabendo quando eu iria vê-lo novamente, então eu não temia por mim nessa situação. ${ }^{105}$

Em seguida, todavia, a narradora coloca em questão essa falta de temor e reflete "E se não fosse realmente verdade que eu não estava com medo naquele momento, não seria a primeira vez em que eu não admitiria para mim mesma a minha própria vulnerabilidade.."106, expondo um mecanismo de defesa observado em todo o romance, além de uma capacidade de ausentar-se psicologicamente das situações de violência, uma reação típica de crianças que vivem em situação de abuso. Um primeiro exemplo disso é que, durante o castigo aplicado por Ma Eunice, Xuela encontra os jabutis e volta todas as atenções para eles, tirando assim o foco da posição de desamparo em que ela, uma criança pequena, se encontra.

Outro exemplo dessa defesa aqui exposta ocorre na escola, quando a professora está humilhando Xuela pela descoberta das cartas, supostamente escritas ao pai, e a menina mantém os olhos e o pensamento concentrados em uma aranha, que enxerga por trás dos ombros da professora, e no som da chuva que escuta cair no telhado da escola. Prestar atenção em outra coisa, ausentar-se psicologicamente da situação de

\footnotetext{
105 "I was not afraid, because my mother had already died and that is the only thing a child is really afraid of; when I was born, my mother was dead, and I had lived all those years with Eunice, a woman who was not my mother and who could not love me, and without my father, never knowing when I would see him again, so I was not afraid for myself in this situation. (KINCAID, 1997, pp. 14,15).

106 "And if it is not really true that I was not afraid then, it was not the only time that I did not admit to myself my own vulnerability."(Ibid., p.15).
} 
Capítulo 1 Migrações Domésticas

violência, é uma estratégia de sobrevivência utilizada por Xuela a partir de sua infância que sugere um mecanismo de defesa por dissociação ${ }^{107}$.

Com a descoberta das cartas escritas aparentemente para o pai, mas, em verdade, direcionadas à mãe morta, a narradora autodiegética descobre o poder da narrativa como ferramenta para mudança de vida. Como resultado do envio das cartas pela professora para seu pai, ele vem buscá-la e ela vai viver com ele e a madrasta. Esta é a terceira possibilidade de Xuela ter uma mentora, e a última que surge ainda na sua infância. A madrasta, todavia, recebe a menina com hostilidade pois a vê como ameaça ao seu casamento com o pai da narradora.

Xuela reconhece de imediato a falta de amor: "Ela não me amava. Eu podia ver isso no seu rosto. Meu espírito ergueu-se a enfrentar esse desafio. Sem amor: Eu poderia viver em um lugar assim. Eu conhecia muito bem essa atmosfera." ${ }^{108}$ A menina afirma que se ali encontrasse amor, ela seria derrotada, mas considerando a dificuldade declarada anteriormente em lidar com sua vulnerabilidade, ela ainda pode ser considerada aqui como uma narradora não confiável. No episódio da escola, ela confessa que não é a primeira vez que não admitia sua vulnerabilidade. Sendo assim, é possível considerar que talvez o amor na casa da madrasta pudesse, ao contrário da crença infantil de aniquilamento de Xuela, restaurar a capacidade de amar da menina, ainda com sete anos. Como, no entanto, ela já identifica a falta de amor com que é recebida, conforta-se com o fato de possuir recursos para viver em um ambiente assim, ao qual já estava acostumada. Por outro lado, o amor da madrasta, se existisse, poderia ter quebrado sua resistência, conduzindo a uma assimilação, por ela indesejada.

\footnotetext{
107 De acordo com Negro Jr. et al (1999) a dissociação pode funcionar, dentre outras formas, como um mecanismo de defesa conectado a diversos fenômenos, como amnesia psicológica ou, o que parece mais o caso, como a eliminação do sofrimento físico ou emocional, além da possível não integração crônica da personalidade. Segundo afirmam Negro Jr. et al (1999), Pierre Janet defende que a dissociação como mecanismo de defesa não tem origem proposital ou funcional, mas que surge quando o indivíduo experimenta fortes emoções (inclusive terror) que o levam ao estreitamento do campo atencional e a desorganização da integração das informações na consciência.

108 "She did not love me. I could see it in her face. My spirit rose to meet this challenge. No love: I could live in a place like this. I knew this atmosphere all too well." (KINCAID, 1997, p. 29)
} 
A última possível mentora, Mme LaBatte, recebe, junto ao marido, Xuela com quinze anos de idade. A moça vai morar com o casal para continuar os estudos, conforme determinado pelo pai e, em troca de estadia e alimentação, ajuda nos serviços domésticos. Na chegada de Xuela, Mme La Batte informa que a moça deve vê-la como uma mãe. Ela é afetuosa e tida pela narradora autodiegética como uma amiga, talvez a única amiga de toda a sua vida. No entanto, Mme LaBatte tem a expectativa de que Xuela atenda os desejos sexuais do marido e the dê o filho que ela não pode ter. Quando a narradora engravida do Monsieur LaBatte, ela se afasta da casa para realizar um aborto e impede assim a realização desse desejo. Embora a mulher esteja de luto, quando Xuela retorna à casa dos LaBatte, ela recebe a moça com carinho, o que parece demonstrar que o afeto que the dedica vai além do desejo de usá-la como instrumento para tornar-se mãe. Mesmo sendo imperfeita, Mme LaBatte é a única possível mentora de Xuela que a trata com afeto e que estabelece com ela uma ligação tão forte que as duas se comunicam por telepatia. Apesar dessa forte ligação, no seu retorno após o aborto, Xuela, modificada pela traumática experiência, sente que a permanência na relação com a mulher terminaria por consumí-la totalmente e decide partir para não mais voltar.

Como resultado da falta de amor em seu crescer, Xuela, como afirmado anteriormente, torna-se sua própria mentora, embora ela mesma reconheça as limitações dessa situação e revele sua admiração para com aqueles que acompanham o desenvolvimento e o desabrochar de uma vida, da infância à idade adulta. Reconhecendo essas limitações, ela reflete:

Ninguém me observou e contemplou, eu me observei e contemplei; a corrente invisível saiu e entrou em mim. Eu passei a me amar em desafio, a partir do desespero, pois não havia nada mais. Um amor assim serve, mas apenas serve, não é o melhor tipo de amor; ... Serve, mas apenas porque não há nada mais para ocupar o seu lugar; não é um amor a ser recomendado. ${ }^{109,110}$

\footnotetext{
109 Tradução minha.

110 "No one observed and beheld me, I observed and beheld myself; the invisible current went out and came back to me. I came to love myself in defiance, out of despair, because there was nothing else. Such a love will do, but it will only do, it's not the best kind; ...It will do, but only because there is nothing else to take its place; it is not to be recommended." (KINCAID, 1997, pp. $56-57$ ).
} 
Capítulo 1 Migrações Domésticas

Essa falta de amor leva Xuela a uma sensação de não pertencimento, que assim como o que ocorre com Ponciá Vicêncio, favorece sua movimentação. Não há o que prenda Xuela a nenhum dos lares em que ela vive e, portanto, o movimento é facilitado. De fato, dos romances que compõem o corpus desta tese, The Autobiography of My Mother é o que apresenta maior quantidade de deslocamentos físicos por parte da protagonista, embora todas suas movimentações ocorram no espaço geográfico de uma ilha caribenha de $751 \mathrm{~km}^{2(111)}$, a ilha de Dominica.

Quando nasce, Xuela é levada pelo pai para a casa da lavadeira, que fica responsável por cuidar da menina. Aos sete anos, aprendendo a escrever cartas na escola, escreve diversas cartas endereçadas ao pai, embora esclareça que de fato as escrevia pensando em sua mãe morta. Mesmo ela não tendo a intenção de enviar as cartas que descreviam sua infelicidade e as escondendo embaixo de uma pedra na escola, a professora acaba descobrindo-as e as encaminha para o pai da menina. Ele, que já havia se casado com outra mulher, vem buscar a menina e a leva para morar junto com ele e a esposa. Mais tarde, aos 15 anos, vai morar com os LaBatte em Roseau, conforme mencionado anteriormente. Quando engravida de seu senhorio e aborta o bebê, Xuela afasta-se da casa, buscando ajuda de Sange-Sange, uma mulher conhecida na ilha por fornecer ervas medicinais e também xaropes abortivos.

Depois do aborto, a protagonista realiza um percurso espiritual. Nesse percurso, Xuela circunda toda a ilha de Dominica tomando posse do que ela denomina seu direito de nascença. Optar pela leitura desse percurso da protagonista como uma alucinação seria como negar a visão do menino que se afoga no rio atraído por Mama Dglos, uma opção pela versão do colonizador. Sendo assim, entendo que ela de fato realiza esse percurso em espírito e toma posse da ilha que é sua terra por direito.

Após essa experiência, Xuela é encontrada pelo pai e retorna à casa dos LaBatte por um breve período. Durante esse retorno, ela reflete sobre a educação formal que lhe é proporcionada, uma educação que nunca poderia

\footnotetext{
${ }^{111}$ De acordo com o site oficial do governo da Dominica: http://www.dominica.gov.dm/about-dominica/country-profile.
} 
Capítulo 1 Migrações Domésticas

Ihe oferecer nenhuma satisfação, que apenas a enchia de perguntas sem respostas, e que a levaria inevitavelmente a um estado de permanente humilhação, pois só tinha como intenção exaltar o colonizador e diminuir o colonizado. Decide assim, abandonar os estudos definitivamente.

Considero fundamental observar que, partindo desse pensamento, Xuela inicia uma reflexão sobre sua identidade e, assim como nos romances Ponciá Vicêncio ${ }^{112}$ e Lucy $^{113}$, a ser analisado no próximo capítulo, observa que o processo de nomeação dos sujeitos da diáspora africana estabelece um apagamento das origens e um impedimento de conexão com o passado histórico que se configura traumático. Xuela questiona a identificação tanto de seus pais, quanto dela própria, com seus respectivos nomes e denuncia que: "em uma vida como a dela [a mãe], assim como na minha, o que é um nome verdadeiro?" 114 Ela ressalta ainda que o nome de uma pessoa é ao mesmo tempo sua história recapitulada e abreviada e que ao declarar seu nome uma pessoa pode situar-se em sociedade em uma posição alta ou baixa. Possuir, assim, um nome que não reflete sua história original, mas sim o processo de dominação e violência estabelecido pelo passado da escravidão, consiste em uma dinâmica extremamente destruidora. Uma dinâmica que a narradora autodiegética classifica como uma humilhação que poderia apenas intoxicar alguém com um sentimento de ódio por si próprio.

Após sua decisão de deixar a casa dos LaBatte, Xuela passa a viver isoladamente, trabalhando na construçāo de uma estrada. Ali ela enfrenta as consequências psicológicas do aborto e passa por longo período de introspecção e reflexão. Com o aviso de que seu meio-irmão estava à beira da morte, retorna à casa do pai. A irmã casa-se e o pai, temendo que o marido da irmã seduza Xuela, a envia para viver e trabalhar com um amigo médico e sua esposa. Quando a esposa do médico morre, tendo consumido, com o auxílio de Xuela, ervas alucinógenas que, ao fim da vida, deixaram sua pele pálida negra, a narradora autodiegética casa-se com ele. Em seu último movimento na ilha, Xuela muda-se, com o marido, para um local

\footnotetext{
112 EVARISTO, 2003.

113 KINCAID, 1990.

114 “...for in a life, like hers, as in mine, what is a real name?"(KINCAID, 1997, p.79)
} 
Capítulo 1 Migrações Domésticas

isolado perto das montanhas, em um território que havia pertencido aos caribes, tribo de sua mãe.

Viúva, Xuela continua nas montanhas até o fim da narrativa, em que reflete sobre o relato de sua vida como um relato individual, seu, mas também de uma coletividade oprimida pelo poder colonial, um relato da vida de sua mãe e dos filhos que Xuela impediu de vir ao mundo. Nesse ponto, Xuela menciona a pessoa que a ela não foi permitido ser e a pessoa que ela mesma não se permitiu ser. Essas impossibilidades podem ser inferidas das constantes reflexões feitas ao longo do romance com relação às limitações impostas pelas relações colonizador-colonizado.

O não pertencimento de Xuela, sua impossibilidade de conexão com a mãe e o povo Caribe, com quem ela deseja se identificar e sua recusa em aceitar os papéis (mulher, mãe, Caribe, do povo africano, ou descendente de brancos) que a sociedade colonial the impõe, dentro de uma hierarquia colonial e patriarcal determinada, são os facilitadores das diversas movimentações de Xuela. Ela não pertence e não deseja pertencer a nenhuma categoria determinada por esses sistemas e, sendo assim, movimenta-se sempre que se sente pressionada a encaixar-se em alguma dessas categorias.

The Autobiography of My Mother é a narrativa que apresenta um maior foco na relação entre dominadores e dominados, em comparação às outras narrativas do corpus desta tese. Essa temática, assim como a orfandade de Xuela, com a mãe morta ao nascer e um pai que, embora vivo, ela não pode nunca conhecer verdadeiramente, é repetida exaustivas vezes. A impossibilidade de receber amor e amar demonstrada e repetida por Xuela, durante toda a narrativa, é conectada a essas duas questões: a perda da mãe, e do amor que poderia ter recebido dela, e do pai, que embora vivo, a abandona sem amor; e a vivência do colonizado em sua relação histórica de violência com o colonizador, gerando também como herança uma relação de desconfiança e ódio entre os próprios colonizados, uma hierarquização baseada na perniciosa assimilação dos costumes e da cultura dos colonizadores para a obtenção de alguma medida de poder. 
Logo no início, a narradora autodiegética nos informa que sua trajetória se dará em um lugar em que “... a brutalidade é a única herança real e a crueldade é por vezes a única coisa dada gratuitamente."115 116 domínio britânico é aparente desde o início do romance, indicado por objetos, como o prato de Ma Eunice que Xuela, criança, simbolicamente quebra e que ostenta a palavra "PARAíSO"117 118, abaixo de uma pintura de uma cena bucólica inglesa, bem como o apreço desmedido que a dona tem pelo objeto; ou por situações como a entrada de Xuela no mundo escolar e as primeiras palavras que lá aprende a ler: "O IMPÉRIO BRITÂNICO"119, 120.

A narradora autodiegética aponta a presença de colonizados e colonizadores inúmeras vezes no texto, nominando-os, por vezes, derrotados e vitoriosos; outras vezes, dizimados e vencedores. O castigo que Ma Eunice aplica a Xuela quando ela quebra o seu prato de estimação, e recusa-se a pedir desculpa, também reflete essas relações. Com esses adjetivos Xuela descreve a relação colonial na ilha de Dominica. Essa relação desequilibrada de poder favorece a conexão do lugar de fala do colonizado com o Fantástico, o Gótico, enquanto o poder do Colonizador permanece legitimado sem que se possa questioná-lo.

É utilizando-se de elementos do gótico que a experiência de Xuela e seus colegas quando veem um dos meninos do grupo morrer afogado, atraído para o fundo do rio por um ser sobrenatural, é retratada. Esse ser, uma mulher, rodeada de lindas mangas, que emitia um som estranho, porém doce, é uma figura folclórica comum a lendas de diversas ilhas caribenhas, e também de outros países da diáspora africana, que é chamada na Dominica de Mama Dlo ou Mama Dglo ${ }^{121}$. Embora a população assimilada pela cultura

\footnotetext{
115 Tradução minha.

116 "... brutality is the only real inheritance and cruelty is sometimes the only thing freely given." (KINCAID, 1997, p.5)

117 Tradução minha.

118 "HEAVEN"

119 Tradução minha.

120 "THE BRITISH EMPIRE” (Ibid., p.14)

121 Mama Dlo, ou Mama Dglo, tem seu nome originário do francês maman de l'eau, significando mamãe da água. É metade mulher, metade cobra, mas pode apresentar-se como uma linda mulher que aparece nas águas, atraindo homens que serão seus esposos nesta vida e na próxima. (BESSON, 1994) Embora o texto refira-se à lenda em Trinidad e Tobago, Mama Dlo é encontrada em diversas ilhas do Caribe, incluindo a ilha de Dominica e
} 
Capítulo 1 Migrações Domésticas

britânica do colonizador considere a aceitação do sobrenatural como uma desqualificação de sua civilidade, a narradora autodiegética reivindica a realidade de sua experiência, reafirmando ter visto o garoto com quem ia para escola nadar nu em direção a uma mulher também nua e desaparecer nas águas, onde o rio encontra o mar. Xuela reafirma também que a mulher não era de fato uma mulher, que era um ser que havia tomado forma de uma mulher. Ela opta pela aceitação do sobrenatural.

Esse episódio fantástico, aqui utilizado como elemento do gótico, é, desse modo, incorporado à realidade do colonizado. Quanto à experiência do Fantástico, Todorov ${ }^{122}$ afirma que ela só dura enquanto dura a hesitação comum ao leitor e à personagem, que precisam decidir se o que é apresentado se origina ou não da realidade conhecida. Ao final, o leitor decide, mesmo que esta não seja a mesma decisão tomada pela personagem. Caso o leitor entenda que as leis da realidade continuam intactas e possibilitam uma explicação do fenômeno descrito, a obra pertence ao gênero Estranho, também chamado de Sobrenatural Explicado, conforme Todorov. Caso o leitor decida que as leis da natureza conhecidas não são suficientes para proporcionar uma explicação ao fenômeno, então ele se encontra diante do gênero do Maravilhoso, ou Sobrenatural Aceito.

Em The Autobiography of my Mother, Xuela sugere que renegar a experiência sobrenatural porque passou é renegar a visão do colonizado e optar pela visão do colonizador. E é essa também a escolha que precisa fazer o leitor, a aceitação do sobrenatural na narrativa permite uma aliança do leitor com os derrotados a quem Xuela também se alia, enquanto que a leitura das experiências sobrenaturais do romance como surperstições ou fantasias implica uma aliança com a leitura do colonizador a respeito do colonizado.

Para o fato de alguns amigos que presenciaram a cena com ela, duvidarem eles mesmos do que viram, Xuela apresenta uma explicação que expõe essa relação íntima do gótico com a experiência do colonizado:

outros países da diáspora Africana, com algumas variações. (http://en.wikipedia.org/wiki/Mami_Wata acessado em 31 de outubro de 2014).

122 TODOROV, 1975. 
Tudo sobre nós é mantido em dúvida, e nós os derrotados definimos tudo o que é irreal, tudo o que não é humano, tudo o que é sem amor, tudo que é sem piedade. Nossa experiência não pode ser interpretada por nós; nós não conhecemos sua verdade. Nosso Deus não é o correto, nosso entendimento de paraíso e inferno não é respeitável. A crença naquela aparição de uma mulher nua com os braços estendidos levando um garotinho para a morte era a crença dos ilegítimos, dos pobres, dos baixos. Eu acreditei nessa aparição então e acredito nela agora. ${ }^{123} 124$

A recusa de Xuela em assimilar-se, em não deixar de crer na sua própria experiência, é tanto uma resistência à dominação colonial quanto uma recusa a identificar-se com seu pai, que sendo filho de um escocês com uma africana, opta pela assimilação e por não apenas renegar os costumes dos dominados, mas também repetir a opressão contra seus pares, aliandose ao poder colonial e opressor para obtenção de benefícios próprios. A narradora autodiegética percebe essa posição do pai que, segundo ela, usa uma máscara a vida toda, como no título da obra de Fanon ${ }^{125}$. O pai de Xuela usa uma máscara branca em um rosto negro. Ser mestiço facilita sua ascensão no meio colonial e ele usa esse fato para aproximar-se do poder dos brancos, oprimindo a população local negra, roubando, enganando e enriquecendo às custas de seus semelhantes.

Xuela, por outro lado, reivindica seu papel de derrotada, negando os benefícios de qualquer característica conectada ao que poderia ser considerado civilizado, ou seja, britânico. Ela reivindica tudo o que nela é nativo, inclusive os seus odores: "Eu amava o cheiro da fina sujeira atrás das minhas orelhas, o cheiro da minha boca não lavada, o cheiro que vinha do meio das minhas pernas..."

\footnotetext{
${ }^{123}$ Tradução minha.

124 "Everything about us is held in doubt and we the defeated define all that is unreal, all that is not human, all that is without love, all that is without mercy. Our experience cannot be interpreted by us; we do not know the truth of it. Our God was not the correct one, our understanding of heaven and hell was not a respectable one. Belief in that apparition of a naked woman with outstretched arms beckoning a small boy to death was the belief of the illegitimate, the poor, the low. I believed in that apparition then and I believe in it now. (KINCAID, 1997, p.37)

${ }_{22}$ FANON, Franz. Black Skin, White Masks. 1952.

126 "I loved the smell of the thin dirt behind my ears, the smell of my unwashed mouth, the smell that came from between my legs ..." (KINCAID, 1997, p. 32).
} 
A narradora autodiegética questiona a visão de mundo imposta pelos colonizadores, critica o ódio entre seus iguais, promovido pelo poder colonial e repetido entre pessoas que deveriam se unir por serem parte do mesmo sofrimento, da mesma opressão, pessoas que haviam sido escravizadas e que, no entanto, em vez de direcionarem sua revolta e desconfiança para o dominador, desconfiavam delas próprias e inculcavam esse sentimento em suas crianças, propagando a opressão por outras gerações. Em certa passagem, Xuela relata que seu pai dizia a ela "Você não pode confiar nessas pessoas" ${ }^{\text {"127 }}$ e que essas palavras eram também repetidas pelos pais das outras crianças. Ela tem consciência de que essas pessoas são parte de um mesmo povo, que compartilhou uma história de sofrimento, humilhação e escravidão e que as pessoas a quem, de fato, ela e seus colegas deveriam dirigir essa desconfiança estavam fora do seu alcance. Mais ainda, aquilo que era verdadeiramente necessário para derrotar essas pessoas era "algo muito mais poderoso que a desconfiança". 128

A narradora autodiegética compara a situação de desconfiança entre os seus como se houvesse uma competição entre eles, uma competição por um prêmio secreto. Sendo assim, quanto mais eles se aproximassem da cultura colonizadora, quanto mais negassem sua real origem e sua coletividade, mais próximos eles estariam desse prêmio. Xuela ressalta aqui o sentimento de terror em que viviam ela e seus colegas, um terror oriundo da obrigatoriedade de desconfiança entre os seus, junto à intuição de uma força opressora muito maior, conectada ao passado da escravidão e à opressão colonial presente, à negação da própria experiência e do próprio ser. A narrativa utiliza-se aqui do sobrenatural gótico para expressar o temor dessas crianças, a única força que os unia: "Não eramos amigos. Caminhávamos juntos em uma companhia baseada no medo, medo de

127 "You cannot trust these people"

128 "something much more powerful than mistrust" (KINCAID, 1997, p.48) 
Capítulo 1 Migrações Domésticas

coisas que não podíamos ver [...] Nós conversávamos, mas a nossa conversa era sempre sobre o terror." 129

Relembrando a experiência sobrenatural do afogamento do colega, Xuela afirma que caso o processo de formação educacional dela e de seus amigos fosse bem sucedido, a maioria deles terminaria por não acreditar em sua própria experiência. Ela afirma que dizer terem visto um menino ir em busca de uma mulher no meio das águas e, assim, desaparecer seria considerada uma declaração de que viviam em uma escuridão da qual não poderiam ser salvos e para qual não poderia haver redenção. A narradora autodiegética afirma mais uma vez a reinvindicação do lugar de fala do derrotado, como forma de resistência, pois para ela a redenção não tinha nenhuma utilidade, nem quando criança, nem quando adulta. $\mathrm{O}$ episódio do afogamento do colega mostra-se importante também no que concerne à opção de assimilação do pai de Xuela, que faz questão de dizer à menina que ela não tinha visto o que dizia ter visto, uma posição alinhada com a visão do colonizador. Logo em seguida, a narradora reflete sobre a herança genética da palidez do pai.

A opção do pai por unir-se ao dominador na opressão dos colonizados é alvo de reflexão contínua de Xuela, da infância à maturidade. $E$ é nesse último momento que ela descreve de forma mais pungente a formação híbrida do pai e sua opção pela identidade que lhe parecia, individualmente, mais conveniente. Ela também demonstra maior compreensão, afirmando que, em uma situação como a deles, apenas os santos escolhem viver entre os que andam de cabeça baixa e não entre os que caminham de cabeça erguida e que mesmo assim, os santos sabem que ao final serão eles a andar de cabeça erguida. Xuela, no entanto, parece encontrar um caminho alternativo. Embora possa como o pai optar pela assimilação e acatar sua identidade ligada ao colonizador, ela alia-se sempre aos derrotados e, principalmente, aos dizimados caribes. Sua aliança não implica, todavia, em agir como os santos que esperam a

129 "We were not friends. We walked together in a companionship based on fear, fear of things we could not see [...] We would talk, but our conversation was always about terror." (KINCAID, 1997, p.48) 
chegada ao paraíso para andarem de cabeça erguida. Xuela mantém sua cabeça erguida, negando os valores coloniais e patriarcais. Mesmo quando casa com um homem inglês, utiliza-se de estratégias que impedem sua dominação e promovem, ao contrário, um revide do colonizado para com o colonizador, que é quem termina por ser colocado em uma posição frágil e inferiorizada. Essa opção de vida, entretanto, possui um preço que a narradora autodiegética reconhece ao final do romance: o isolamento e a solidão. Ao fim da vida, Xuela espera pela morte como a única coisa a qual ela pode se submeter. Ela reconhece que o relato de sua vida é também o relato da vida da mãe que ela nunca conheceu e dos filhos que ela nunca permitiu nascer. É, assim, um relato de faltas, inclusive da pessoa que o seu ambiente, suas condições de vida, nunca permitiram que fosse; a pessoa que ela mesma nunca se permitiu ser. 


\section{Capítulo 2 Migrações Transnacionais}

O segundo capítulo desta tese destina-se a analisar os romances Lucy, de Jamaica Kincaid ${ }^{1}$, publicado pela primeira vez em 1990, e Breath, Eyes, Memory, de Edwidge Danticat ${ }^{2}$. As protagonistas dos romances, Lucy e Sophie, se deslocam de seus países periféricos para os Estados Unidos, migrações transnacionais que são parte importante do seu processo de formação.

\section{Lucy, o anjo caído e as possibilidades infinitas no caminho das identidades múltiplas}

Lucy, romance de Jamaica Kincaid, narra a vida de Lucy Josephine Potter, uma moça do Caribe que migra para os Estados Unidos, aos 19 anos, possivelmente, para Nova York, embora a cidade não seja nunca explicitada. A narrativa inicia-se com a chegada de Lucy ao país, para ser au-pair na casa de um casal americano que tem quatro filhas. Lucy, assim como Ponciá Vicêncio ${ }^{3}$ e The Autobiography of my Mother ${ }^{4}$, é um romance de formação pós-colonial e, dessa forma, utiliza as etapas desse gênero literário em sua forma tradicional, subvertendo-as para que alcancem a experiência da protagonista, uma moça negra, criada em um sociedade periférica, colonial e patriarcal.

A viagem é a primeira etapa típica do romance de formação observada em Lucy e constitui-se em uma segunda diáspora, visto que a moça, cujos ascendentes se presentificam no Caribe devido à diáspora africana acarretada pelo tráfico negreiro, faz parte de uma leva de grande

\footnotetext{
${ }^{1}$ KINCAID, 2002.

2 DANTICAT, 1998.

${ }^{3}$ EVARISTO, 2003.

${ }^{4}$ KINCAID, 1997.
} 
migração do Caribe para países como a Inglaterra, França e Estados Unidos, caso da narrativa. Stuart $\mathrm{Hall}^{5}$ afirma que, na diáspora, as identidades ao mesmo tempo que se tornam múltiplas, favorecem também uma identificação do sujeito com um grupo maior. O autor menciona especificamente a situação do caribenho na diáspora que, além de identificar-se com sua ilha de origem, passa a identificar-se como caribenho, o que por vezes não ocorre quando permanece nela. Hall ${ }^{6}$ afirma sobre sua geração que imigrou para a Inglaterra, que ela "tornou-se caribenha', não no Caribe, mas em Londres!"’ A migração de Lucy ocorre com o apoio da família e com o intuito de buscar aprimoramento social e econômico, motivação típica do Bildungsroman tradicional. O aprimoramento a ser buscado, no entanto, é limitado, visto que a mãe de Lucy deseja que a filha se torne enfermeira, profissão que considera socialmente adequada a uma mulher. As limitações impostas à formação de Lucy são, portanto, os primeiros indícios do uso das convenções do romance de formação na variante pós-colonial.

A mãe apresenta-se como a primeira mentora de Lucy e, até a menina completar nove anos de idade, a relação das duas flui de maneira amorosa e harmoniosa. Quando, todavia, a partir dos seus nove anos, a mãe de Lucy tem um filho homem atrás do outro, como descreve a protagonista, essa relação modifica-se e assemelha-se às relações entre pupilo e mentor dos Bildungsromane pós-coloniais.

Os mentores desse gênero, como observado anteriormente, mostram-se, de modo geral, inadequados e incapazes de conciliar as funções típicas do mentor tradicional, proteger a protagonista e, ao mesmo tempo, salvaguardar a ordem social. Os interesses da ordem social são de tal modo conflitantes com a possibilidade de desenvolvimento do bildungsheld que é praticamente impossível garantir uma coisa e outra.

Sendo assim, os mentores terminam por ser, como verificado em Lucy, falhos e com a função de antimodelos na formação da protagonista.

\footnotetext{
${ }^{5} \mathrm{HALL}, 2003$.

${ }^{6}$ Id., 2003.

7 Ibid., p.27.
} 
Esse é o caso da Mãe de Lucy e de Mariah, sua patroa nos Estados Unidos. O momento em que a mãe dá a luz a três filhos homens, é o momento em que se mostra a impossibilidade de uma formação por meio de sua tutela para Lucy. Sua mãe, junto ao pai, faz inúmeros planos de conquistas para os filhos do sexo masculino, mas não para a menina. Já nos Estados Unidos, Lucy relembra:

cada vez que nascia mais um filho, minha mãe e meu pai anunciavam um para o outro com grande seriedade que o novo filho iria à universidade na Inglaterra e estudaria para tornar-se médico ou advogado ou para ocupar uma posição importante e influente na sociedade.

Embora Lucy refira-se tanto ao pai quanto à mãe em sua reflexão, uma questão de gênero pode ser aqui observada, com a representação de uma realidade de um sistema patriarcal que não apenas subjuga as mulheres, mas as torna repetidoras de um discurso que oprime a elas próprias. O ressentimento de Lucy é direcionado, portanto, muito mais a sua mãe que a seu pai, justificando assim essa sua mágoa:

Meu pai não me conhecia nadinha; não esperava que sonhasse para mim uma vida divertida e plena de sucesso. Mas minha mãe me conhecia bem, tão bem quanto conhecia a si mesma: eu, à época, nos julgava idênticas; e sempre que via seus olhos encherem-se de lágrimas só de pensar no orgulho que sentiria com algum feito dos filhos, sentia uma espada traspassar meu coração, pois não havia nenhum cenário em que ela me visse, seu único rebento idêntico, em situação remotamente semelhante. ${ }^{9}$

A decepção e a revolta de Lucy para com a mãe impedem que a relação Mentora/Bildungsheld continue a ocorrer. A repetição por parte da mãe de Lucy de um discurso patriarcal, que rebaixa a mulher a uma posição sempre subalterna, é considerada pela menina Lucy como uma traição, tanto

\footnotetext{
8 "each time a new child was born, my mother and father announced to each other with great seriousness that the new child would go to university in England and study to become a doctor or lawyer or someone who would occupy an important and influential position in society." (KINCAID, 2002, p.130)

9 "My father did not know me at all; I did not expect him to imagine a life for me filled with excitement and triumph. But my mother knew me well, as well as she knew herself: I, at the time, even thought of us as identical; and whenever I saw her eyes fill up with tears at the thought of how proud she would be at some deed her sons had accomplished, I felt a sword go through my heart, for there was no accompanying scenario in which she saw me, her only identical offspring, in a remotely similar situation. (Ibid., p.130).
} 
que ela apelida a mãe de "Sra. Judas"10 e começa a planejar separar-se dela desde então, embora suspeitando que essa nunca poderia ser uma separação definitiva.

Em Caribbean Genesis: Jamaica Kincaid and the Writing of New Worlds, Jana Evans Braziel ${ }^{11}$ examina a identificação de Lucy com a origem do seu nome "Lúcifer", conforme informado por sua mãe, quando questionada pela garota. Braziel ${ }^{12}$ teoriza as relações ideológicas e de poder dos nomes e a questão do indivíduo diaspórico como diabólico. Concordo com a autora quando afirma que Lucy, assim com Lúcifer, não apenas reclama para si uma história de queda e um paraíso perdido, mas cria "novos mundos" para sua vivência diaspórica.

Movimento, migração e diáspora, assim como a queda de Lúcifer, representam uma mobilidade através do espaço e do tempo, embora não precisem significar perdas irreparáveis. Para Braziel ${ }^{13}$, em Lucy, Antigua e Nova York são representadas por parâmetros espaço-temporais dicotômicos, sendo a Antigua ligada ao passado, à mãe, à terra-mãe, "mother-land"14 no original; enquanto Nova York, assim como Mariah, é a mãe-substituta, um duplo da mãe, a diáspora e o futuro. A ilha de Antigua é descrita como um lugar quente, ensolarado, tropical. Paradoxalmente a essa imagem do Éden, é também descrita como um lugar infernal, opressor, em que Lucy não encontra perspectivas. Nova York, por sua vez, embora fria e cinzenta, é a possibilidade do novo, da libertação, de uma autogênese para Lucy.

Concordo com Braziel ${ }^{15}$ quando avalia que o espaço da terra-mãe e da diáspora se encontram também internalizados em Lucy. Ela retorna, mentalmente, à Antigua e à sua mãe com frequência, sempre em busca de construir sua identidade, independente das limitações impostas tanto pela mãe como pela sociedade periférica e patriarcal de onde veio.

\footnotetext{
10 "Mrs Judas" (Ibid., p.130)

${ }^{11}$ BRAZIEL, 2009.

12 Id., 2009.

${ }^{13}$ Id., 2009.

14 lbid., p.82.

${ }^{15}$ BRAZIEL, op. cit.
} 
Capítulo 2 Migrações Transnacionais

A relação entre Lucy e sua mãe também é alvo de reflexão de Braziel $^{16}$ que compara Lucy a Lúcifer, e sua mãe, a Deus. Lucy é, de acordo com a autora, "uma criação angelical de uma mãe divina, embora um anjo caído." 17 . Lucy se sente como se tivesse sido criada com o único propósito de ser um eco de sua mãe e, a isso, ela prefere a morte.

Tal como Lúcifer, Lucy cai, migrando para longe do domínio de sua mãe/Deus. Fugir de sua mãe é também fugir de sua "terra mãe", considerada por Braziel ${ }^{18}$ tanto como Antigua quanto como a Grã Bretanha. De uma perspectiva pós-colonial, a autora considera também a mãe de Lucy como uma metáfora do colonizador, sendo Lucy o colonizado que busca independência e resiste à dominação que pretende mantê-lo limitado e à disposição dos interesses da metrópole.

Braziel $^{19}$ considera a migração de Lucy como uma fuga. Embora eu observe aqui que a migração se dá com a permissão e aceitação da família, é possível considerar esse movimento de Lucy como uma fuga, se considerarmos que o apoio da família para sua imigração não coincide, em nenhum momento, com as intenções da moça ao partir. Para a autora, essa fuga, além de diaspórica, é diabólica, no sentido em que proporciona a queda de Lucy/Lucífer do paraíso Mãe/Deus. Embora seja a agente de sua própria queda, Lucy se declara inúmeras vezes como rejeitada, banida, especialmente quando se leva em consideração as expectativas de seus pais para com os filhos homens e a falta de planos para o destino de Lucy. Sua queda, todavia, é o que Ihe possibilitará realizar mudanças, criar outros mundos, e sobre essas possibilidades tratarei mais à frente de maneira mais detalhada.

A identificação da mãe de Lucy com a figura de Deus, por parte da filha, é verificada por Braziel ${ }^{20}$ em diversas instâncias, pois Lucy sentia que a mãe queria torná-la um eco de si, como Deus, criando-a à sua imagem e semelhança. Ela identifica a mãe com uma entidade divina, embora não do

\footnotetext{
${ }^{16}$ BRAZIEL, 2009.

17 "an angelic creation of the godlike mother, though fallen." (Ibid., p.85).

${ }^{18}$ BRAZIEL, op. cit.

${ }^{19}$ BRAZIEL, op. cit.

${ }^{20}$ BRAZIEL, op. cit.
} 
Capítulo 2 Migrações Transnacionais

tipo benevolente, assemelhando-se a uma entidade vingativa, opressora, dominadora e punitiva: "No romance de Jamaica Kincaid, a mãe é divina, embora diabólica e mesmo vilanil: 'uma bola de fúria, gigante como um deus'". 21

No que diz respeito à Lucy como Lucífer, a questão da nomeação e a dificuldade de identificar-se com o próprio nome, que lhe é atribuído em consonância com o processo histórico de colonização e opressão, mostra-se fundamental. Assim como nos romances Ponciá Vicêncio ${ }^{22}$ e The Autobiography of my Mother ${ }^{23}$, analisados no capítulo anterior, a protagonista de Lucy não consegue encontrar identificação com seu próprio nome. Ela relaciona a origem do sobrenome Potter com o nome do senhor de escravos, opressor de seus antepassados; e relembra um tio rico, Joseph, a quem os pais quiseram agradar, na esperança de que ele a beneficiasse financeiramente, dando-lhe o nome do meio de Josephine. A protagonista rejeita esses nomes e passa também a buscar nomes alternativos para o prenome Lucy pois não consegue enxergar substância ou força nele.

Suas opções de troca de nome, entretanto, são aindas ligadas ao processo de colonização do qual, de um modo ou de outro, ela não consegue escapar totalmente. Ao pensar no significado e origem dos seus nomes, Lucy começa a pensar que o seu primeiro nome the parece insignificante e que gostaria de ser chamada como as autoras dos livros que lia, Charlotte, Emily, referindo-se às irmãs Brontë, ou Jane, que provavelmente refere-se ou à escritora Jane Austen ou à personagem Jane Eyre de Charlotte Brontë. Um dia, ela decide-se pelo nome Enid, da escritora Enid Blyton. Ao comunicar sua opção à mãe, entretanto, é recebida com uma reação assustadora, a bola de fúria divina, já descrita anteriormente. Ela abandona o assunto, mas descobre que a reação da mãe ao nome Enid deve-se ao fato de que uma mulher chamada Enid, apaixonada por seu pai,

\footnotetext{
21 "In Kincaid's novel Lucy, mother is divine, yet evil, even villainous: 'she was a ball of fury, large, like a god' " (BRAZIEL, 2009, p.86).

${ }^{22}$ EVARISTO, 2003.

${ }^{23}$ KINCAID, 1997.
} 
havia tentado matar a ela e sua mãe por meio de $O b e a h^{24}$.

Como a própria Lucy declara, quando já não mais se importa com os sentimentos de sua mãe, resolve questionar sobre seu nome novamente, e pergunta porque a mãe resolveu dar-lhe o nome de Lucy, ao que ela responde: "Eu a chamei de Lucy em homenagem a Satã. Lucy, contração de Lúcifer." ${ }^{25}$ Essa descoberta para a protagonista é inicialmente um choque, mas torna-se uma experiência libertadora. Ela descreve que passa de sentirse velha e sobrecarregada para sentir-se leve, nova e limpa. Esse é o momento da queda de Lucy/Lúcifer, uma queda que permite tanto uma identificação com os anjos caídos, conhecidos por ela de suas primeiras leituras do Gênesis e do Paraíso Perdido, de John Milton; quanto um marco do processo de libertação de sua mãe/Deus. A respeito da revelação de sua mãe e da relação entre elas que se esclarece nesse momento, Lucy reflete: "Que minha mãe me achasse diabólica não me surpreendeu, pois eu, com frequência, a considerava divina, e não são os filhos dos deuses demônios?" ${ }^{26}$. A partir desse momento, embora declare que preferisse ter sido chamada de Lúcifer diretamente, Lucy passa a olhar seu nome com mais carinho.

Concordo com Braziel ${ }^{27}$ quando considera a queda de Lucy/Lúcifer como uma abertura para um potencial criativo, gerador de palavras e mundos. O papel do anjo caído em Lucy não é o papel de uma vítima apenas, é um papel regenerador e criador. Como um ser diabólico e diaspórico, nos termos de Braziel ${ }^{28}$, Lucy é capaz de criar novos mundos a habitar, realizando movimentos e sendo agente causador e transformador da vontade divina.

É como um anjo caído que Lucy chega aos Estados Unidos, com todo o sofrimento inerente ao processo de queda, mas com a possibilidade

\footnotetext{
${ }^{24}$ Obeah, como mencionado no capítulo sobre The Autobiography of My Mother é uma prática religiosa de matriz africana em que se fazem trabalhos espirituais tanto para oferecer proteção como para atacar outras pessoas.

25 "I named you after Satan himself. Lucy, short for Lucifer." (KINCAID, 2002, p.153).

26 "That my mother would have found me devil-like did not surprise me, for I often thought of her as god-like, and are not the children of gods devils?" (KINCAID, 2002, p.153).

${ }^{27}$ BRAZIEL, 2009.

${ }^{28}$ Id., 2009.
} 
Capítulo 2 Migrações Transnacionais

de novos caminhos e espaços. Mariah, a dona de casa americana, apresenta-se como uma possível nova mentora, um duplo da figura materna. A presença dessa nova mentora, na diáspora, poderia indicar um processo semelhante ao que são submetidos os protagonistas dos Bildungsromane tradicionais, entretanto, a falha de Mariah em perceber a subjetividade de Lucy fora da sua visão colonizadora, a não aceitação passiva do pensamento colonizador de Mariah, por parte de Lucy, e a contestação desse pensamento, criam uma situação diversa em que a protagonista passa a aprender por seus mecanismos internos de reflexão, à revelia dos ensinamentos da mentora.

Mariah funciona, assim, como uma mentora às avessas e Lucy se desenvolve mais por meio das vivências proporcionadas por ela e por suas próprias reflexões do que por meio dos ensinamentos que Mariah procura passar. De fato, ao recusar as "verdades" do mundo de Mariah e impor sua alteridade, Lucy é quem funciona como um tipo de mentora para a americana, provocando reflexão e mudança em sua vida.

Uma situação que representa muito bem essa questão ocorre quando, com o início da primavera, Mariah leva Lucy, vendada, para ver os narcisos em flor. Lucy já havia relatado o trauma vivenciado por ter tido, sem nunca ter visto um narciso na vida, de memorizar um poema inglês sobre eles, tendo que declamá-lo em frente a toda escola quando tinha dez anos. Mariah, não entendendo a sujeição, a opressão, e a revolta envolvidas no relato de Lucy, segue a lógica do seu próprio meio e cultura e tenta impô-la à Lucy, surpreendendo-a com a beleza que vê nos narcisos. A reação de Lucy força Mariah ao encontro com o ponto de vista do colonizado, do outro, para ela, totalmente desconhecido. Lucy diz: "'Mariah, você faz ideia de que aos dez anos de idade tive que aprender de cor um longo poema que falava de flores que não veria na vida real até completar dezenove anos?"”29 e continua, refletindo sobre o efeito dessa revelação em Mariah, sobre a perda de sua inocência e o abismo que as separa e impede uma verdadeira comunicação entre as duas:

\footnotetext{
29 "Mariah, do you realize that at ten years of age I had to learn by heart a long poem about some flowers I would not see in real life until I was nineteen?" (KINCAID, 2002, p.30).
} 
Assim que disse isso me arrependi de apresentar seus amados narcisos numa cena que jamais havia considerado, uma cena de conquistados e conquistas; uma cena de brutos mascarados de anjos e anjos retratados como brutos. Essa mulher que mal me conhecia, me amava e queria que eu amasse essa coisa - um bosque transbordando de narcisos em flor - que ela também amava. Seus olhos se encolheram dentro da cabeça como se se protegessem, como se descansassem após um trabalho árduo e inesperado. Não era culpa dela. Não era minha culpa. Mas nada poderia mudar o fato de que onde ela via belas flores eu via tristeza e amargura. A mesma coisa poderia nos fazer derramar lágrimas, mas essas lágrimas não teriam o mesmo gosto. ${ }^{30}$

Mais adiante, quando da estada na região dos Grandes Lagos, a fala de Lucy demonstra sua compreensão quanto às ingênuas intenções de Mariah para com as suas filhas e a protagonista em si, como se fossem todas crianças em formação: "Mariah queria que todas nós, as crianças e eu, víssemos as coisas como ela via. Queria que aproveitássemos a casa, todos seus cantos e recantos, todos os seus doces perfumes, todos os seus encantos, exatamente do mesmo jeito que fizera quando criança." ${ }^{31}$ Continuando sua reflexão, Lucy percebe que foi justamente a sensação de que sua mãe queria fazer dela um eco seu, o que terminou por fazer com que ela fosse embora do seu país. Esse movimento levou-a, todavia, ao encontro de uma outra mulher que repetia o mesmo comportamento: "uma mulher que queria me mostrar seu mundo e esperava que eu gostasse também."32

Embora a ida para os EUA tenha tido como intenção escapar das limitações de sua mãe e da sociedade local, Lucy conclui que de algumas

\footnotetext{
30 "As soon as I said this I felt sorry that I had cast her beloved daffodils in a scene she had never considered, a scene of conquered and conquests; a scene of brutes masquerading as angels and angels portrayed as brutes. This woman who hardly knew me, loved me and she wanted to love this thing - a grove brimming over with daffodils in bloom that she loved also. Her eyes sank back in her head as if they were protecting themselves, as if they were taking a rest after some unexpected hard work. It wasn't her fault. It wasn't my fault. But nothing could change the fact that where she saw beautiful flowers I saw sorrow and bitterness. The same thing could cause us to shed tears, but those tears would not taste the same." (KINCAID, 2002, p.30).

31 "Mariah wanted all of us, the children and me, to see things the way she did. She wanted us to enjoy the house, all its nooks and crannies, all its sweet smells, all its charms, just the way she had done as a child." (Ibid., p. 35-36).

32 "a woman who wanted to show me her world and hoped that I would like it, too." (Ibid., p.36).
} 
questões não é possível escapar apenas com uma mudança geográfica, mas que "o esforço em tentar pode servir perfeitamente por um tempo"33. Braziel $^{34}$, como já dito anteriormente, faz uma leitura de Lucy como Lucífer e sua mãe como Deus. No que diz respeito a Mariah, no entanto, a autora a considera como uma semi-deusa. Ela repete alguns dos desejos da mãe de Lucy, como este de criar ecos de si própria, mas ao mesmo tempo é capaz de gestos amorosos e humanos que a aproximam de Lucy e possibilitam reflexões, tanto para uma quanto para a outra.

Ainda assim, as falas de Mariah mostram-se, na maioria das vezes, permeadas pela visão do colonizador que se enxerga na posição de ensinar ao colonizado um modo de vida superior e que, mesmo quando tenta aproximar-se do colonizado, o faz por uma via de dominação, como uma tomada de posse. Um exemplo desse tipo de fala pode ser observado em uma conversa desconfortável entre Mariah e Lucy, que mais uma vez rejeita as estratégias da mentora e questiona duramente seus pontos de vista. A conversa tange a questão de uma identidade híbrida ou mestiça que, para Lucy, encontra-se ligada, não apenas à ascendência diaspórica, mas também ao processo de mestiçagem. Suas diversas identidades não são reivindicadas, a não ser em momentos de confronto como esse em que Lucy se aborrece com a afirmação de Mariah de que tinha sangue índio e que atribuía sua habilidade na pesca, na caça às aves e até mesmo em assar milho a essa origem. Após contar isso à Lucy, a própria Mariah intui que não devia ter dito aquilo e que seria mal entendida por Lucy.

Da sua posição, Mariah não pode entender a visão de Lucy, pois a americana descende do colonizador e, mesmo ao apontar uma possível mestiçagem em sua origem, o faz a partir do olhar desse colonizador que reduz esse outro, índio, aos estereótipos de caçador, pescador e assador de milho. É esse reducionismo e a pretensão de dominação do outro que incomoda Lucy profundamente:

Isso realmente me surpreendeu. Como deveria entender isso? Mal? Bem? Que queria dizer? Olhando-a, não havia

\footnotetext{
33 "... often the effort of trying will do quite nicely for a while." (Ibid., p. 37).
}

${ }^{34}$ BRAZIEL, 2009. 
nela nada nem remotamente parecido com índio. Por que dizer uma coisa dessas? Eu também tinha sangue índio. Minha avó era uma índia caribe. Isso me fazia ter um quarto de sangue de índio caribe. Mas não saio por aí dizendo que tenho sangue índio. Os índios caribes eram bons marinheiros, mas não gosto de andar no mar; só gosto de ver. ${ }^{35}$

Mariah é vista por Lucy como pertencente ao grupo dos colonizadores, por ser branca e descendente deles. Sua condição de americana, mesmo os Estados Unidos sendo também uma ex-colônia britânica, a coloca historicamente ao lado dos opressores. Além disso, a forma como tenta incorporar a alteridade indígena à sua identidade, considerando também a posição neocolonialista americana, acaba aumentando o sentimento de revolta de Lucy, que questiona de si para si: "Como se acaba sendo um tipo de vitorioso que pode reivindicar o papel do aniquilado também?"36

Um outro diálogo importante que Lucy tem com Mariah ocorre após a protagonista saber da morte de seu pai, com um mês de atraso, por meio da visita de uma conhecida caribenha. Mariah fica então sabendo que as cartas enviadas pela mãe de Lucy haviam todas sido guardadas sem nunca ser abertas e indaga à moça: "Por que não perdoa sua mãe pelo que quer que sinta que ela lhe fez? Por que simplesmente não volta para casa e lhe diz que a perdoa?"37 A pergunta de Mariah faz com que Lucy rememore os motivos que a fizeram odiar sua mãe e o que impossibilita seu retorno: a falta de perspectiva dentro de sua estrutura familiar patriarcal e da sociedade periférica, e também patriarcal, que deixou para trás. Em Antigua e próxima de sua mãe, Lucy não enxerga possibilidade de libertação dos padrões impostos. Nos Estados Unidos, como o outro, o diaspórico, é que ela começa a enxergar uma possibilidade de transformação.

\footnotetext{
35 "This really surprised me. What way should I take this? Wrong way? Right way? What could she mean? To look at her, there was nothing remotely like an Indian about her. Why claim a thing like that? I myself had Indian Blood in me. My grandmother is a Carib Indian. But I don't go around saying that I have some Indian blood in me. The Carib Indians were good sailors, but I don't like to be on the sea; I only like to look at it." (KINCAID, 2002, p. 40) 36 "How do you get to be the sort of victor can claim to be the vanquished also?" (KINCAID, 2002, p.41)

37 "Why don't you forgive your mother for whatever it is you feel she has done? Why don't you just go home and tell her you forgive her?" (Ibid., p.129)
} 
Ao ouvir a história de Lucy, Mariah oferece um auxílio que tem como base uma tradição de pensamento eurocêntrica feminista branca e faz com que Lucy se sinta não vista em sua individualidade. Ela percebe, no entanto, a intenção de ajudá-la: "Mariah quis me salvar. Falou das mulheres na sociedade, mulheres na história..." ${ }^{38}$ Apesar de Mariah, em geral, não possuir o arsenal adequado para ajudar Lucy a resolver seus conflitos, suas observações e propostas, mesmo ingênuas, por todo o romance engatilham os processos de reflexão de Lucy, que favorecem o seu amadurecimento. Após o diálogo acima citado, por exemplo, pode-se observar que Lucy toma, de fato, a decisão de mudar-se da casa de Mariah, exercendo o movimento que gerará uma nova etapa em sua vida. O último capítulo mostra a protagonista sem um final fechado como os que ocorrem tipicamente nos romances de formação tradicionais, mas um final aberto de uma personagem ainda em construção como a sociedade pós-colonial de onde ela é originária.

Mariah, como uma mentora falha de um Bildungsroman pós-colonial mostra-se, inicialmente, como guardiã dos valores sociais da sociedade dominante e, mesmo que de modo inconsciente, privilegia esses valores na formação de Lucy. A protagonista, por sua vez, rejeitando os ensinamentos de Mariah, utiliza-os para refletir sobre sua condição de outro, colonizado, estrangeiro, mulher, o que acarreta em outro tipo de formação, impossível em um Bildungsroman tradicional. É interessante observar que durante um ano de convivência com Lucy, Mariah também passa por um certo despertar. Durante esse ano, ela passa por um processo de separação do marido, descobrindo posteriormente que ele a havia trocado por sua melhor amiga, com quem tinha um caso já há certo tempo. No último encontro de Mariah e Lucy, é possível compreender a incrível mudança por que passou Mariah durante o período de convivência com Lucy e em consequência de todas as mudanças em sua vida. Mariah informa à protagonista que está de mudança com as filhas para um lugar de extrema beleza natural e que as pessoas que

\footnotetext{
38 "Mariah wanted to rescue me. She spoke of women in society, women in history..." (Ibid., p.131)
} 
Capítulo 2 Migrações Transnacionais

moravam nesse lugar tratavam-se todas com amor e se cumprimentavam com a palavra "Paz". Considerando o período histórico do romance, fica claro que Mariah vai abandonar Nova York e integrar o movimento hippie do final dos anos sessenta, começo dos anos setenta, em uma transformação profunda do seu estilo de vida.

Outro evento característico do Bildungsroman, a iniciação romântica, possui, de acordo com Vázquez ${ }^{39}$, menor importância nos romances do gênero da variação pós-colonial. O que se observa, com mais frequência, nesses romances é a presença de atrações românticas não consumadas, relações platônicas, o não alcance da maturidade sexual ou mesmo dificuldades na aceitação da própria identidade sexual. Em vários casos, a sexualidade do(a) protagonista transcende o âmbito do que é aceito pela sociedade em que vive, sendo que sua incapacidade de estabelecer relações sancionadas pela comunidade denuncia a inexistência de um projeto social capaz de garantir a integração do herói/heroína.

No que diz respeito à iniciação romântica de Lucy, o que se dá de fato é uma iniciação sexual, sem o romantismo envolvido nas iniciações dos Romances de Formação clássicos. Lucy relata sua primeira experiência sexual como uma decisão consciente de livrar-se do fardo da virgindade: "Não fazia questão de ser virgem e há muito andava antegozando o dia em que me livraria dessa condição..." 40 . Lutando sempre contra a aceitação de sua posição como a de um outro dominado, ao perceber o valor dado pelo colega, parceiro dessa primeira experiência, ao fato de ela ser virgem, afirma que a mancha na toalha usada era apenas de menstruação e reflete quanto a sua fala: "...quando percebi a grande importância que dava a ter sido o primeiro rapaz a andar comigo, não pude lhe dar esse poder sobre mim." ${ }^{41}$ Todos os relacionamentos de Lucy desde essa primeira experiência sexual parecem basear-se em um temor de ser dominada, colonizada pelo outro. Há sempre uma resistência à entrega e, sempre que pressente a ameaça

\footnotetext{
${ }^{39}$ VÁZQUEZ, 2003.

40 "I did not care about being a virgin and had long been looking forward to the day when I could rid myself of that status..." (KINCAID, 2002, p.82-83)

41 "... when I saw how much it mattered to him to be the first boy I had been with, I could not give such a hold on me." (Id. Ibid., p.83)
} 
dessa colonização, ela decide afastar-se.

A primeira relação romântica/sexual de Lucy nos Estados Unidos ocorre no verão, quando ela vai para a casa do lago da família de Mariah. Ela se identifica com Hugh, o irmão de Dinah, amiga de Mariah. Hugh acabara de retornar de uma viagem pelo mundo e consegue partilhar com ela a experiência de ser estrangeiro, de estar longe de tudo o que se conhece. É preciso, de todo modo, ressaltar que ser estrangeiro para Hugh ainda siginifica estar em um lugar de maior privilégio do que para Lucy, pois ele é um homem, branco, americano, que mesmo estando fora de seu país encontra sempre mais portas abertas do que a moça caribenha. Embora Lucy interesse-se por Hugh, tanto por sua pouca idade, quanto por sua busca por independência, ela nunca vê seu caso com o rapaz como algo que possa ultrapassar o verão. E acolhe com antecedência sua separação como algo natural.

Um dos relacionamentos afetivos mais significativos que Lucy estabelece, no entanto, é com sua amiga Peggy, uma descendente de irlandeses que conhece em Nova York. O relacionamento de Lucy e Peggy ultrapassa os limites da amizade, conforme entenderia a sociedade americana dos anos sessenta, quando elas passam a noite juntas se beijando. Esta não pode ser considerada, todavia, a primeira experiência de Lucy fora dos padrões aceitos pela sociedade da época, visto que ela relata outras experiências homosexuais, como com a colega de escola com quem treina os primeiros beijos.

Peggy, que pode também ser considerada como outra mentora de Lucy, tem a mesma idade da moça, mas é responsável por apresentar à protagonista outros ambientes da cidade grande que não aqueles frequentados pela família de Mariah. Filha de imigrantes irlandeses de classe operária, é com ela que Lucy anda pela cidade, frequenta bares e festas, fuma maconha e conhece homens. É com ela também que se muda da casa de Mariah, optando por continuar em Nova York.

Todavia, embora sejam amigas, Lucy sempre mantém sua atitude crítica para com Peggy. Mesmo no princípio da amizade, a protagonista tem 
consciência de suas diferenças. Ela afirma quanto à Peggy: "O engraçado era que Peggy e eu também não éramos parecidas, mas era exatamente isso o que gostávamos uma na outra; o que não tínhamos em comum eram coisas que de todo modo aprovávamos." 42,43 Mais à frente, tendo aprendido com Peggy a "sabedoria das ruas", Lucy começa a sentir o peso das diferenças entre elas, o que dá o primeiro sinal de futuro afastamento: "Minha amizade com Peggy estava chegando a um impasse previsível; nossas pequenas diferenças começavam a se agigantar, às vezes parecendo a única coisa que importava - como um grão de areia no olho." 44,45

É por meio de Peggy que Lucy conhece Paul, um artista plástico, branco, com quem mantém um relacionamento mais longo. Desde o início, no entanto, Lucy se sente observada por Paul como se fosse um ser exótico. Quando se conhecem em uma festa na casa dele, ela se compara às plantas tropicais expostas no apartamento, consideradas quase como uma praga em sua terra de origem, mas merecedoras de um lugar de destaque na decoração do apartamento de Paul, iluminadas por uma luz azul. Lucy estabelece um paralelo entre a situação das plantas e a sua, quando sente o olhar de Paul, que tem olhos azuis, fixo sobre ela.

O relacionamento de Lucy e Paul é mantido essencialmente pela questão sexual. Da parte de Lucy, o que parece mais interessar a ela é a possibilidade de experimentação que Paul the proporciona. A experimentação, todavia, não é algo que ocorre somente quando ela está com ele, pois Lucy relata uma relação sexual que tem com o homem que the vende a câmera fotográfica. Roland é um imigrante panamenho que, de acordo com a descrição da protagonista, se parece com seu pai. Lucy passa uma tarde na cama com ele, no dia em que o conhece, e segue para

42 "The funny thing was that Peggy and I were not alike, either, but that is just what we liked about each other; what we didn't have in common were things we approved of anyway." (KINCAID, 2002, p. 61)

${ }^{43}$ Tradução minha.

44 "My friendship with Peggy was reaching a predictable stalemate; the small differences between us were beginning to loom, sometimes becoming the only thing that mattered - like a grain of sand in the eye." (Ibid., p. 94)

${ }^{45}$ Tradução minha. 
encontrar-se com Paul, logo depois.

Lucy perde o interesse por Paul quando este começa a demonstrar que a ama, o que ela interpreta como uma tentativa de controle e dominação. O momento chave para esse desinteresse ocorre quando ele a fotografa nua, da cintura para cima, cozinhando. Nesse momento, ela sente como se ele a quisesse, de algum modo, possuir, dominar e afirma ter, ali, perdido o interesse por ele. Como havia passado por inúmeras perdas recentemente, a moça não termina o relacionamento e espera que um dia, Paul o faça. Ao fim do romance, eles ainda se relacionam, embora Lucy saiba que ele está envolvido com sua amiga Peggy. Sua única preocupação a esse respeito é a de que eles possam se aborrecer ao perceberem que ela já sabe do envolvimento e que não se importa.

Observo aqui que o caminho de Lucy para tornar-se uma adulta funcional, assim como o de Ponciá ${ }^{46}$ e Xuela ${ }^{47}$, ocorre de modo diverso ao das protagonistas dos Bildungsromane tradicionais, sendo o caminho da variação pós-colonial do gênero. Como afirma Maria Helena Lima ${ }^{48}$, os escritores pós-coloniais usam o romance de formação para criar uma ficção que ajude a entender/explicar e constituir o sujeito pós-colonial, explorando as contradições e complexidades de crescer em uma região onde as relações pós-coloniais e raciais são exacerbadas pelo patriarcado. Também o despatriamento ${ }^{49}$, nas narrativas pós-coloniais, é um despatriamento real e não transcendental, como o descrito por Lukács ${ }^{50}$ em que a a alma busca ser testada para se provar e encontrar a própria essência. O despatriamento e a alienação nas narrativas pós-coloniais possuem referentes históricos concretos que não podem ser alcançados pela linguagem figurativa de Lukács apenas. Também não é suficiente entendê-los, de acordo com Lima $^{51}$, como a situação de deslocamento e contingência por que passam as mulheres, conforme descrevem Gilbert e Gubar em sua análise de Jane

\footnotetext{
${ }^{46}$ EVARISTO, 2003.

${ }^{47}$ KINCAID, 1997.

${ }^{48}$ LIMA, 1993.

49 "homelessness", no original. (LIMA, 1993, p.442)

${ }^{50}$ LUKÁCS, 1971 (apud LIMA, 1993, p.442-443)

${ }^{51}$ LIMA, op. cit.
} 
Eyre.

O despatriamento em sua forma mais literal, como aparece nos romances de formação pós-coloniais, demanda uma articulação muito mais ampla. Desse modo, as memórias de Lucy, do seu crescer no Caribe, mostram-se permeadas pela articulação da realidade pós-colonial, das imposições do sistema patriarcal e das questões raciais da sociedade da ilha de Antigua, ex-colônia britânica. Mais ainda, suas vivências, enfrentamentos e questionamentos na diáspora continuam articulando-se a essas questões e também estabelecendo paralelos tanto com a realidade pós-colonial dos Estados Unidos e a situação dos afro-americanos quanto com a posição desse país como potência central neocolonizadora e imperialista.

Além de a narrativa seguir a variante pós-colonial do romance de formação, é possível observar, como na trajetória de Xuela, em The Autobiography of my Mother ${ }^{52}$, interferências de outros gêneros, como o Gótico. Convenções do gênero são utilizadas em $L_{u c y}{ }^{53}$ para retratar a experiência marginal e periférica da protagonista, como um sujeito duplamente diaspórico, em sua origem e em sua migração para os Estados Unidos. A comparação de Lucy com Lúcifer, por si só, já é um indicativo de uma convenção gótica utilizada no romance, especialmente porque está conectada com a figura do Diabo do Paraíso Perdido de Milton. A Glossary of Literary Gothic Terms ${ }^{54}$, doravante Glossary, ressalta, em sua entrada para o vocábulo Diabo ("Devil” no original), a poderosa caracterização de Milton de um satanás brilhante, orgulhoso e quase trágico, em Paraíso Perdido, que influenciou profundamente a evolução do herói-vilão gótico. Lucy mostra-se, de fato, uma heroína-vilã em seus conflitos e em sua humanidade, além de ela, como Lucífer, constituir-se em um outro que cai em um universo diferente, em busca de uma vivência alternativa e menos limitada que a que possuía no Paraíso anterior. Além dessa caracterização de Lucy como heroína-vilã identificada com Lúcifer, diversas outras convenções góticas podem ser localizadas no texto.

\footnotetext{
${ }_{52}^{5}$ KINCAID, 1997.

${ }^{53}$ KINCAID, 2003.

${ }^{54}$ THOMSON, 2015.
} 
Evie Shockley, em "The Horrors of Homelessness: Gothic Doubling in Kincaid's Lucy and Brontë's Vilette" ${ }^{, 55}$, embora equivocadamente classifique Lucy como um romance resultante de uma tradição cultural afroamericana, e a própria Jamaica Kincaid como uma escritora afro-americana, desse modo, desconsiderando, em uma postura colonizadora, as especificidades do contexto tanto caribenho quanto diaspórico de que justamente trata Kincaid em seu romance, apresenta o conceito de despatriamento gótico ${ }^{56}$ em sua comparação entre Lucy e Vilette, de Charlotte Brontë. A comparação entre os romances não é interessante para o objetivo desta tese, entretanto o conceito de despatriamento gótico o é, podendo acrescentar à discussão aqui em foco.

Shockley ${ }^{57}$ afirma que a marginalidade social de Lucy favorece uma condição que é, ao mesmo tempo, psicológica, por provocar um desconforto que perturba a mente, e social, por acarretar uma sensação de ser tratada pelos outros como portadora de uma anomalia social. A autora detalha o despatriamento gótico como sendo o estado do indivíduo que não consegue, ou não quer, desempenhar as normas privilegiadas ideologicamente e termina por se localizar fora ou às margens da sociedade e dos espaços privilegiados por ela. Ressalto aqui que no caso de Lucy, colocar-se contra a estrutura colonial e patriarcal de sua sociedade, recusando os papéis limitados que lhe são ofertados, resulta nesse despatriamento gótico, que a impulsiona ao, já mencionado, movimento do não pertencimento, comum às protagonistas de todos os romances da presente tese.

Concordo com Shockley ${ }^{58}$ quando ressalta que o ambiente de personagens como Lucy se encontra saturado de elementos do terror e horror gótico, tendo a protagonista que deparar-se com o pesadelo duplo de enxergar os limites identitários da ideologia doméstica, ao mesmo tempo em que percebe sua incapacidade de controlar esses limites para alterá-los ou transgredi-los e obter assim um resultado social que a satisfaça. Para que

\footnotetext{
${ }^{55}$ SHOCKLEY, 2010 apud LANG-PERALTA, 2010.

56 "gothic homelessness", no original. (SHOCKLEY, 2010 apud LANG-PERALTA, 2010, p.49).

57 SHOCKLEY, op. cit.

${ }^{58}$ SHOCKLEY, op. cit.
} 
Lucy transgrida e ultrapasse esses limites pré-estabelecidos é necessário que ela abandone sua terra natal e realize uma migração transnacional. Os temores e terrores originários, todavia, permanecem tanto em sua análise do passado quanto do presente diaspórico e podem ser verificados nas diversas convenções góticas presentes no romance, como o duplo na relação Lucy/Mãe e Lucy/Mariah e entre Antígua, o lugar normalmente descrito como paradisíaco, mas que se mostra infernal; e Nova York, o local frio e inóspito que pode oferecer sonhos e liberdade. Outras convenções do gênero observadas são: a presença da figura Miltoniana do Demônio e do duplo no romance, o sobrenatural representado pela prática do Obeah, a possessão pelo demônio da garota de Antígua que tem que se mudar para o outro lado do mar para que o demônio não possa segui-la e as ruínas desoladas pelas quais, de acordo com Lucy, Paul mostra-se fascinado.

O Gótico é uma das ferramentas no romance que possibilita narrar a história de um Outro como Lucy, um Outro que de fato se movimenta e se torna mulher, apoiando-se em sua alteridade, aceitando-a e reforçando-a. Ao trilhar seu caminho para a maturidade, Lucy precisa aceitar sua subjetividade como múltipla e fragmentada, uma identidade pós-moderna, conforme o conceito de identidade cultural na pós-modernidade, de Stuart Hall ${ }^{59}$, em que o sujeito pós-moderno não é entendido como proprietário de uma identidade única e estável, mas é composto por diversas identidades, por vezes contraditórias ou não resolvidas. É com essa perspectiva de uma identidade múltipla e de possíveis rumos a seguir que o romance chega ao fim. Assim como com as protagonistas de Ponciá Vicêncio ${ }^{60}$ e de The Autobiography of my Mother ${ }^{61}$, a movimentação de Lucy, tanto ao sair de seu país para os Estados Unidos quanto nesse último país, é impulsionada pelo sentimento de não pertencimento e a busca de um espaço para sua subjetividade complexa. Lucy, entretanto, pertence à classe média da ilha de onde provém e, diferindo de Ponciá, possui mais recursos para lidar com seu processo migratório, mostrando-se capaz de libertar-se das amarras

\footnotetext{
${ }^{59}$ HALL, 1998.

${ }^{60}$ EVARISTO, 2003.

${ }^{61}$ KINCAID, 1997.
} 
regionais e dos papéis de gênero pré-determinados e refletindo sobre sua condição de Outro, colonizado, estrangeiro e mulher de maneira crítica, ao mesmo tempo em que nega as regras impostas pela nova sociedade em que opta viver.

Quando Lucy muda-se da casa de Mariah em busca de novos caminhos, ela opta por não retornar à sua terra natal, onde teria que se conformar aos papéis socialmente determinados pela comunidade que abandonou. A forte personalidade de Lucy, com sua inteligência crítica, possibilita o questionamento tanto do mundo de onde veio, quanto do novo universo com o qual se defronta, a todo momento, sendo possível identificar o processo de sua formação com base na afirmação de sua alteridade ao longo de toda a narrativa. O não retorno da protagonista à sociedade de origem encontra-se em acordo com a variante pós-colonial do Bildungsroman, visto que mantém-se suspenso, com a possibilidade de jamais ocorrer. De todo modo, o retorno ao meio social de origem não é garantia de sucesso e adequação para o indivíduo pós-colonial, especialmente no caso da mulher negra.

Por outro lado, também não há segurança nem estabilidade na opção pela diáspora. Embora fique nos Estados Unidos, Lucy não assimila as normas do novo país em que vive, mantendo os conflitos inerentes à sua alteridade, a sua condição pós-colonial e às identidades fragmentadas e não resolvidas do indivíduo pós-moderno que ela precisa administrar. Todavia, há uma maior esperança no final desta narrativa do que nas outras duas, analisadas anteriormente. Em Ponciá Vicêncio ${ }^{62}$, Ponciá retorna à Vila Vicêncio, por decisão da família, visto que se encontra desconectada da realidade, esculpindo figuras de barro no ar. Xuela, em The Autobiography of my Mother $^{63}$ mantém, até o fim, uma vida sem amor como forma de enfrentar o abandono causado pela morte da mãe, a incapacidade de amar do pai e o ambiente pós-colonial em que vive, também estéril de amor. Uma mulher idosa, Xuela aguarda a morte como o objetivo da vida, como o

\footnotetext{
${ }^{62}$ EVARISTO, 2003.

${ }^{63}$ KINCAID, 1997.
} 
Capítulo 2 Migrações Transnacionais

descanso de sua batalha. Lucy, por sua vez, com todos os conflitos que carrega consigo, com sua identidade múltipla e fragmentada, parece apontar, justamente por isso, para possibilidades infinitas, para novas construções e articulações. É simbólico que no último capítulo ela escreva seu nome completo na primeira página do caderno em branco que ganhou de Mariah. Embora suas lágrimas manchem o nome, embora ela desconheça seus próximos passos, seus próximos movimentos, o futuro é a página em branco em que ela, com todas as suas indagações e complexidades, vai escrever.

\section{Oú Liberé? O fardo da violência sexual e da loucura no crescer de Sophie Caco em Breath, Eyes, Memory.}

Breath, Eyes, Memory, de Edwidge Danticat ${ }^{64}$, narra o processo de formação de Sophie Caco, menina haitiana que, criada por sua tia e sua avó no Haiti, migra para Nova York ao encontro de sua mãe, uma estranha que conhecia apenas por retratos e gravações em fita cassete. $O$ encontro com a mãe e a migração para os Estados Unidos acarretarão em traumas e enfrentamentos que marcarão o processo de formação da menina, começando pela descoberta de que sua existência é resultado de um estupro de sua mãe, então adolescente, possivelmente por um Tonton Macoute ${ }^{65}$. Embora a formação de Sophie seja o foco principal do romance, episódios da formação de Martine, sua mãe, também são narrados em retrospecto. O estupro sofrido por Martine mostra-se, de fato, como o eixo condutor da narrativa e conector das vivências de violência sexual experimentadas, tanto pelas mulheres da família Caco, quanto pelas

\footnotetext{
${ }^{64}$ DANTICAT, 1998.

${ }^{65}$ Os Tonton Macoutes foram uma milícia civil criada no governo de François Duvalier, o Papa Doc. Conforme relata Laurent Dubois em seu livro Haiti: The Aftershocks of History (2013), Clément Barbot, colaborador de Duvalier foi encarregado de criar a milícia que começou a recrutar seus membros em 1959. O nome oficial era Voluntários da Segurança Nacional, mas muitos haitianos começaram a chamá-los de Tonton Makouts, como a figura folclórica que devorava crianças. Os Tonton Makouts foram fundamentais para manter a atmosfera de terror e obediência desejada por Duvalier desde o início do seu governo, uma atmosfera em que ninguém era intocável e nada era sagrado.
} 
mulheres haitianas que possivelmente compartilham a experiência dos testes, para verificação de virgindade, e a violência sexual por parte das forças de manutenção do poder, tanto do Estado quanto do sistema patriarcal no Haiti.

O romance possui uma fortuna crítica significativa e foi possível observar que a maior parte dos títulos remete à questão da violência contra a mulher, em si, ou como índice de uma ordem social patriarcal e póscolonial estabelecida no Haiti. Laura Mellem em seu estudo ${ }^{66}$ publicado em Caribbean Women Writers Independent Study, aponta a conexão existente entre o culto à virgindade pela sociedade haitiana e a prática histórica do estupro coletivo. Mellem chama a atenção inicialmente para a longa história de estupros de mulheres haitianas como ferramenta de controle politico e social. Essa história desmascara as maneiras como a cidadania constitui-se em uma construção engendrada e heterosexualizada que reduz a autonomia sexual e também política, incluo aqui, da mulher haitiana.

Mellem $^{67}$ menciona que Lucía Suarez, em seu livro The Tears of Hispaniola, argumenta que Breath, Eyes, Memory funciona como um ato de rememoração da história real de violência sexual durante as ditaduras dos Duvalier que, de outro modo, tem sido silenciada. Mellem também aponta a análise histórica dos estupros da era Duvalier realizada por Carolle Charles $^{68}$, explicando que, nesse período, eles se tornaram uma tática para o silenciamento das mulheres que se pronunciavam como oponentes do regime, fornecendo como exemplo o caso real de Hakime Rimpel, jornalista e ativista feminista, atacada por Tonton Macoutes, em 1958, um ano após declarar apoio ao candidato oponente de Duvalier. A jornalista foi sequestrada de casa, estuprada diversas vezes e encontrada nua em uma rua próxima à sua casa na manhã seguinte. Mellem ${ }^{69}$ ressalta que embora o caso de Rimpel tenha recebido atenção recentemente, muitas mulheres com

\footnotetext{
66 The (Nation) State of the Family: Remembering the Links Between Collective Rape and the Cult of Virginity in Edwidge Danticat's Breath, Eyes, Memory.

${ }^{67}$ MELLEM, 2014.

${ }^{68}$ CHARLES, 1995 apud MELLEM, 2014.

${ }^{69}$ MELLEM, op. cit.
} 
Capítulo 2 Migrações Transnacionais

experiências semelhantes permanecem silenciadas. Suárez ${ }^{70}$ sugere que a narrativa de Danticat oferece finalmente um espaço de reconhecimento memorial para as vítimas reais de estupro no Haiti que tiveram até hoje suas experiências negadas.

No livro Fictions of Feminine Citizenship, Francis ${ }^{71}$ questiona a prática do estupro na era Duvalier, argumentando que o estupro de Martine, sancionado pelo Estado, revela o quanto a cidadania no Haiti é engendrada e sexualizada. Observa-se uma dupla negação da "cidadania sexual", visto que a repressão política permite sanções às mulheres que incluem o estupro como ferramenta política e a negação da ocorrência do estupro pelo Estado, que tem como base o desprezo sistematizado pelo testemunho das mulheres. O testemunho delas é tratado como sem sentido e inconsequente para a vida política da sociedade haitiana.

O estupro de Martine não tem uma intenção diretamente política, podendo ou não ter sido cometido por um Tonton Macoute. Essa ambiguidade, como Mellem ${ }^{72}$ ressalta, sugere um contexto mais amplo da prática do estupro como algo sancionado pelo Estado haitiano, uma prática não só realizada pelos agentes do Estado, mas que permanece, de todo modo, sem punição e nem, sequer, reconhecimento desse Estado. A revelação do estupro no romance fornece uma voz a uma narrativa silenciada, revelando a vulnerabilidade sexual da mulher, devido à sua marginalidade como cidadã, e a cidadania engendrada no Haiti que relega às mulheres um status cidadão de segunda classe.

Muito importante para a presente análise é pensar o estupro de Martine como algo que é parte do conceito, apresentado por Mellem ${ }^{73}$, de estupro coletivo. Definido como um padrão de violência sexual perpetrado contra a população civil por agentes de estado, grupo politico e/ou étnico, o conceito de estupro coletivo proporciona uma moldura para analisar a violência sexual em ampla escala durante momentos históricos específicos.

\footnotetext{
${ }_{71}^{70}$ SUÁREZ, 2006 apud MELLEM, 2014.

${ }^{71}$ FRANCIS, 2010 apud MELLEM, 2014.

${ }^{72}$ MELLEM, 2014.

${ }^{73}$ Id., 2014.
} 
Apesar de ser um conceito usado, em geral, em contextos contemporâneos, a autora defende que o estupro coletivo pode ser observado como prática, de modo particular na história do Haiti, e de forma mais ampla na história do Caribe, onde a violência das plantações de cana de açúcar serviu como uma ferramenta de controle social racializado e engendrado que facilitou a manutenção do poder do senhorio. Ressalto aqui que o Brasil, compartilhando com o Caribe de uma economia escravagista no seu período colonial, pode ser incluído como executor desse mesmo tipo de prática.

Mellem $^{74}$ indica então outros momentos, além da violência colonial nos canaviais do Haiti. Ela aponta, por exemplo, a violência sexual cometida pelos "marines" americanos durante a ocupação do Haiti pelos Estados Unidos, que consistiu na prática de estupro das mulheres haitianas pelos ocupantes. Quanto ao romance, Francis ${ }^{75}$ associa o nome Caco da família de Sophie com o nome dos grupos camponeses guerrilheiros que resistiram à ocupação americana. Entretanto, a autora ressalta que as mulheres que participavam dessa resistência encontravam-se vulneráveis tanto aos estupros pelos americanos quanto pelos rebeldes Cacos. Um indicativo de que uma violência sexual ocorre em outra geração da família de Sophie são os pesadelos que a avó de Sophie também tem e os sons que Avó Ifé emite durante esses sonhos, de acordo com a neta, muito semelhantes aos de Martine em seus pesadelos, sendo uma das frases emitidas em crioulo, "Lagé mwin", o equivalente em português à "deixe-me em paz". Com essa observação de Sophie, pode-se inferir que a violência sexual não se restrinja à Martine, mas alcance gerações anteriores, como sua Avó Ifé e possíveis ancestrais.

O trabalho de Mellem ${ }^{76}$ enfatiza a existência de uma documentação histórica que comprova a violação sexual das mulheres haitianas desde o estupro de escravas por senhores brancos, capatazes e até mesmo visitantes. Quando da revolução haitiana, os soldados de Dessalines

\footnotetext{
${ }^{74}$ MELLEM, 2014.

${ }^{75}$ FRANCIS, 2010, p.79-80 apud MELLEM, 2014.

${ }^{76}$ MELLEM, op. cit.
} 
Capítulo 2 Migrações Transnacionais

promoveram estupros "retaliadores", contra as mulheres francesas e as mulheres negras que tinham relações voluntárias com franceses, como uma vingança contra os colonizadores franceses que estupravam as mulheres negras no regime escravocrata. Embora essa violência possa ser vista como um revide do colonizado contra o colonizador, consiste, de todo modo, em uma violência de gênero e tem como base o conceito de estupro coletivo, que permite usar a violência sexual contra o corpo da mulher como estratégia de luta política.

No que diz respeito à era Duvalier (de 1957 a 1986), que inclui o governo de Papa Doc e seu filho Jean Claude Duvalier, Mellem ${ }^{77}$ ressalta o uso do estupro como uma ferramenta de repressão política e a atuação nesse sentido da milícia dos Tonton Macoutes, criada na era Duvalier, e responsável por ações de tortura, estupro e execução de mulheres e homens. Voltarei a falar dessa milícia com mais detalhes mais à frente, inclusive pela possibilidade de ter sido um Tonton Macoute o estuprador de Martine, como mencionado anteriormente.

Mellem ${ }^{78}$ prossegue seu estudo mostrando que a prática do estupro coletivo no Haiti continua, mesmo com o fim da era Duvalier, e aponta que durante o governo da junta militar que assumiu por golpe de estado no ano de 1991 e permaneceu no poder até 1994, militares foram responsáveis por estimados 1.680 estupros. Embora esse não seja o período efetivo em que ocorre a narrativa de Breath, Eyes, Memory, é fato que o estupro coletivo constituía no período da escrita do romance, publicado pela primeira vez em 1994, uma realidade extremamente crítica para as mulheres do Haiti.

Em seu artigo "Silences too horrific to disturb: Writing sexual histories in Edwidge Danticat's Breath, Eyes, Memory", Donette A. Francis ${ }^{79}$ examina cinco cenas primárias de sujeição nas quais os corpos das mulheres haitianas pobres (segundo a autora), representados pelas mulheres da família Caco, tornam-se lugar de fala do trauma nacional e da

\footnotetext{
${ }^{77}$ MELLEM, 2014.

${ }^{78}$ Id., 2014.

79 FRANCIS, Donette, 2004.
} 
erosão do corpo político haitiano. Embora a abordagem das cenas de sujeição proposta por Francis $^{80}$ seja interessante dentro da proposta de se acompanhar o crescimento de Sophie na narrativa, pois fornece um panorama das violências sofridas e auto-inflingidas tanto por Sophie quanto por sua mãe, Martine, discordo dessa visão das mulheres da família Caco como mulheres haitianas pobres e questiono se essa conclusão de Francis $^{81}$ não se deve a uma importação de entendimento de riqueza baseada em outro tipo de sociedade, como por exemplo a norte-americana. Para os padrões estadounidenses talvez possa se considerar a situação da família como sendo de pobreza, mas dentro dos padrões da sociedade haitiana isso não ocorre necessariamente. Observo inclusive que Vó Ifé é proprietária de terras e que Sophie frequenta a escola e não trabalha, o que em países subdesenvolvidos poderia talvez ser um indicador de afastamento da linha de pobreza. Além disso, o ataque aos corpos das mulheres haitianas pelas forças de manutenção da ditadura Duvalier não era direcionado apenas às mulheres pobres, mas às mulheres de variadas classes sociais, como observado, por exemplo, no caso da jornalista Hakime Rimpel já citado nesta tese por meio do trabalho de Mellem ${ }^{82}$.

Tendo sido feita essa ressalva, o levantamento das cenas de sujeição realizado por Francis $^{83}$ mapeia a violência contra Martine e Sophie Caco e suas reações que, por vezes, resultam em atos de violência auto inflingida. As cenas de sujeição apontadas por Francis $^{84}$ possibilitam observar cinco momentos cruciais da narrativa que possuem um efeito cumulativo e estão todos conectados de certo modo ao estupro de Martine, já apontado anteriormente como eixo condutor da narrativa. Francis ${ }^{85}$ argumenta que a análise dessas cenas é essencial para o entendimento de como a violência sexual é fundamental para a formação da subjetividade dessas mulheres e de como a desintegração do corpo e do espírito

\footnotetext{
${ }^{80}$ FRANCIS, 2004.

${ }^{81}$ Id., 2004.

${ }^{82}$ MELLEM, 2014

${ }^{83}$ FRANCIS, op. cit.

${ }^{84}$ FRANCIS, op. cit.

${ }^{85}$ FRANCIS, op. cit.
} 
Capítulo 2 Migrações Transnacionais

precedem a dissolução de suas vozes. O conceito de "cenas de sujeição" utilizado por Francis ${ }^{86}$ origina-se dos estudos de Saidiya Hartman ${ }^{87}$ e possibilita identificar momentos na narrativa em que as mulheres sofrem violências, sejam elas de ordem sexual, física ou psicológica.

Embora não concorde com todas as interpretações fornecidas por Francis $^{88}$, a identificação das cenas de sujeição que a autora realiza consistem, por si, em significativa contribuição para que se observe a abrangência da violência contra a mulher na cultura patriarcal haitiana e as consequências destruidoras dessa cultura que atravessam gerações. A primeira cena apontada por Francis ${ }^{89}$ refere-se ao estupro de Martine nos canaviais, além das consequências desse estupro, como a migração para os Estados Unidos com a intenção de deixar o trauma para trás. O fato de Martine ter que abandonar a ilha consiste em outro ato de violência e reflete o desamparo das vítimas de violência sexual na sociedade haitiana em que o estuprador é raramente condenado, conforme relatórios da ONU citados por Francis ${ }^{90}$. Embora Martine migre para os EUA para superar o trauma, este viaja com ela, nas palavras de Francis $^{91}$, e afeta a vida da personagem em Nova York. É possível observar em Martine, anos mais tarde, os sintomas clássicos de Transtorno de Estresse Pós-traumático (TEPT), sobre os quais falaremos em detalhes mais à frente.

A segunda cena de sujeição ${ }^{92}$ diz respeito à prática do "teste" como uma herança traumática passada de mãe para filha na sociedade haitiana. Martine realiza os testes em Sophie porque considera que é sua obrigação de mãe e que o teste é uma forma de proteger a filha. Proteger a filha, desse modo, consiste em repetir um padrão de proteção patriarcal de seu valor como virgem até o dia de seu casamento, uma proteção que é de fato um gesto de violência. Francis $^{93}$ declara que a dissociação experimentada por

\footnotetext{
${ }^{86}$ FRANCIS, 2004.

${ }^{87}$ HARTMAN, 1997 apud FRANCIS, 2004, p. 77.

${ }^{88}$ FRANCIS, 2004.

${ }^{89}$ Id., 2004.

${ }^{90}$ Id., 2004.

${ }^{91}$ Id., 2004.

${ }^{92}$ Id., 2004.

${ }^{93}$ Id., 2004.
} 
Sophie não é, como interpretam alguns críticos, uma desconexão de um indivíduo que sofre uma dor física, mas um estado de dissociação psicológica que tenta separar o corpo material da consciência. Discordo de Francis $^{94}$ quanto à dissociação de Sophie pois entendo esse processo da protagonista como algo que engloba as duas questões citadas pela autora, a necessidade de escapar de uma dor física conectada a um abuso, que é ao mesmo tempo físico e psicológico, é o que provoca dissociação psicológica da experiência da protagonista.

Concordo, todavia, com Francis ${ }^{95}$, quando afirma que a dissociação, embora seja uma forma de sobrevivência, não forneça outras alternativas a longo prazo para elaboração do evento traumático. Sendo um processo de repressão do evento, a dissociação provoca apenas um socorro imediato, deixando a vítima sem recursos para enfrentar as consequências do episódio. Nas palavras de Judith Lewis Herman"96. "embora a dissociação ofereça um meio para uma fuga mental quando não se encontra nenhuma outra saída possível, esse alívio para o terror pode sair a um preço demasiadamente alto."97, 98

A terceira e quarta cenas de sujeição apresentadas por Francis ${ }^{99}$ diferem das duas primeiras por serem cenas de violência auto-inflingida, enquanto as duas primeiras foram exercidas por outrem. Francis ${ }^{100}$ enfatiza que seus corpos são as únicas coisas sobre as quais Martine e Sophie sentem possuir algum poder de controle e é portanto neles que elas exercitam esse poder, como uma forma de resistência. Essa resistência manifesta-se, todavia de forma patológica. Aqui, lembro do caso de Vô Vicêncio, em Ponciá Vicêncio ${ }^{101}$, que mata a esposa e tenta suicidar-se, por não aguentar ver seus filhos sendo vendidos como escravos, mesmo sendo nascidos após a lei do Ventre Livre.

\footnotetext{
${ }^{94}$ FRANCIS, 2004.

${ }^{95}$ Id., 2004.

${ }^{96}$ HERMAN, 1992, p. 239 (apud FRANCIS, 2004, p. 83).

97 " 'though dissociation offers a means of mental escape at the moment when no other scape is possible, it may be that this respite from terror is purchased at far too high a price.'”

98 Tradução minha.

${ }^{99}$ FRANCIS, op. cit.

${ }^{100}$ Id., 2004.

${ }^{101}$ EVARISTO, 2003
} 
Capítulo 2 Migrações Transnacionais

Em Breath, Eyes, Memory, a terceira cena de sujeição apresentada por Francis ${ }^{102}$ é a do pistilo (do almofariz), que é utilizado por Sophie para romper o próprio hímen, como uma forma de se livrar dos testes realizados por sua mãe. Sophie atinge sucesso no seu intento imediato, mas a autoviolação traz consequências. Francis ${ }^{103}$ menciona a contribuição que este ato tem para a fobia sexual desenvolvida por Sophie na relação com o marido e a impossibilidade de enfrentar um parto normal, a que se refere a protagonista quando grávida da primeira filha. Acrescento aqui, também, a destruição física por que passa Sophie, que precisa ser internada em um hospital depois do episódio com o pistilo.

A quarta cena refere-se ao suicídio de Martine, que seriamente traumatizada e nunca tendo tido oportunidade de revisitar sua história com apoio psiquiátrico ou psicológico, é acompanhada por anos pelo trauma do estupro, que revive todas as noites em pesadelo. Quando Martine engravida do namorado, Marc, ela passa a ter alucinações e a acreditar que o bebê que gera fala com ela com a voz de seu estuprador, chamando-a, entre outras coisas, de "puta imunda" ${ }^{104}$. Francis aponta a associação do bebê que Martine espera com o Tonton Macoute e, embora, para efeito da análise da cena de sujeição apresentada, não faça diferença o fato do estuprador ser um Tonton Macoute ou outro homem qualquer. Existe a probabilidade de que tenha sido um Macoute, hipótese levantada por Sophie ${ }^{105}$, e mesmo o temor de que tenha sido um, pelo poder maior que essa milícia exercia. Todavia, há ainda a possibilidade de o estupro ter sido realizado por um civil comum, visto que a impunidade dos casos de estupro no Haiti favorecia essa violência. De todo modo, Martine não se compenetra quanto ao fato de o bebê ter sido concebido de sua relação com seu namorado em Nova York e acredita que ele quer destruí-la. $\mathrm{Na}$ quarta cena de sujeição apontada por

\footnotetext{
${ }^{102}$ FRANCIS, 2004.

${ }^{103}$ Id., 2004.

104 DANTICAT, 1994, p.217 apud FRANCIS, 2004.

${ }^{105}$ DANTICAT, 1998, p. 139.
} 
Francis $^{106}$, Martine esfaqueia, dezessete vezes, a própria barriga com uma faca enferrujada, matando o bebê que gerava e a ela mesma.

Como afirmado anteriormente, as cenas de sujeição apresentadas no estudo de Francis $^{107}$ mapeiam a violência contra a mulher no romance em foco e a relação de violência que se estabelece através de gerações na sociedade patriarcal haitiana, entretanto, embora concorde com as quatro primeiras cenas apresentadas pela autora, discordo que a quinta cena por ela descrita possa ser considerada uma cena de sujeição. A quinta cena, apresentada por Francis $^{108}$, ocorre após o enterro da mãe de Sophie e é na verdade um momento de enfrentamento simbólico e de libertação. A protagonista corre em direção ao canavial e golpeia furiosamente a plantação, local da morte de seu avô, assim como do pai de Ponciá Vicêncio $^{109}$ e local do estupro de sua mãe. Essa cena é apontada por Francis ${ }^{110}$ como um passo para o bem estar de Sophie e um ato de cura e, exatamente por isso, mostra-se contraditório inclui-la entre as cenas de sujeição.

Em sua dissertação de mestrado Struggle for Independence: Postcolonialism reflected in the problematic parent-child relationships in the works of Jamaica Kincaid and Edwidge Danticat, Hanna Tuurala ${ }^{111}$ compara a relação entre país e filhos em Breath, Eyes, Memory, My Brother e The Autobiography of my Mother à relação entre o colonizador e o colonizado. Embora a comparação seja pertinente, a equiparação dos pais, mesmo os mortos no caso de Xuela em The Autobiography of my Mother, com a metrópole colonizadora, seja ela a Inglaterra ou a França, se mostra simplista e ignora os processos de assimilação e a incorporação dos valores do colonizador pelo colonizado para alcançar status mais alto na sociedade pós-colonial e a repetição dos padrões coloniais de opressão em uma hierarquia de poder dentro da ex-colônia. O colonizado, todavia, mesmo que

\footnotetext{
${ }^{106}$ FRANCIS, 2004.

${ }^{107}$ Id., 2004.

${ }^{108}$ Id., 2004.

${ }^{109}$ EVARISTO, 2003.

${ }^{110}$ FRANCIS, op. cit.

111 TUURALA, 2008.
} 
Capítulo 2 Migrações Transnacionais

repetidor da lógica opressora do colonizador, não é nunca equiparado a este na lógica da metrópole e continua em uma situação de opressão, mesmo quando assimilado e usufruindo de posição hierárquica mais alta na excolônia.

Sendo assim, embora tenha observado que a comparação de Tuurala $^{112}$ não contempla toda a complexidade das relações entre pais e filhos das obras por ela analisadas, não sendo útil, neste aspecto, para a presente tese, entendo que a autora apresenta observações valiosas no que diz respeito à luta por independência de Sophie Caco com relação ao sistema patriarcal dentro de um contexto social e familiar e quanto à utilização do corpo como instrumento de resistência tanto por Sophie quanto por sua mãe, Martine. Para tanto recorre à Ketu Katrak que, segundo a autora, enfatiza a importância do corpo feminino como local de resistência na literatura feminista do terceiro mundo. Ela ressalta que o uso do corpo feminino como resistência à dominação é extremamente importante por ser este, às vezes, o único veículo disponível para a resistência, embora possa ser um meio que acarrete consequências trágicas.

Uma das circunstâncias em que Sophie utiliza o corpo como meio de resistência é o momento em que realiza uma autoviolação para dar fim aos testes de virgindade realizados por sua mãe. A autoviolação atinge o fim desejado por Sophie, mas acarreta mais uma camada de trauma sexual aos abusos que já vinha sofrendo com os testes, trazendo como consequência enormes dificuldades no relacionamento sexual com seu marido e um transtorno bulímico. Esse funciona como a única forma de controle que Sophie consegue exercer em seu corpo, visto que depois dos abusos e da auto-violação não se sente no controle de sua vida sexual. É significativo que as crises bulímicas ocorram depois das relações sexuais com o marido, momentos em que ela se dissocia, do mesmo modo que fazia durante os testes. Após o ato sexual, Sophie vai à cozinha, come todos os restos de comida que pode encontrar e vai ao banheiro para vomitar tudo o que comeu, de certo modo, limpando o seu corpo.

112 TUURALA, 2008. 
Capítulo 2 Migrações Transnacionais

Os atos de resistência de Sophie, embora possam ser autodestrutivos, são controlados e por fim encaminham-na a uma forma mais saudável de resistência, porque ela procura ajuda psicológica, coisa de que dispõe na sociedade urbana e americana para onde migrou. É assim que, após a morte de sua mãe, volta para enterrá-la no Haiti e enfrenta corporalmente e simbolicamente o estuprador de sua mãe e toda a violência histórica racial e de gênero, representada pelo canavial, das "plantations" do passado e local da violência sexual sofrida por sua mãe. Essa última utilização do corpo como resistência por Sophie é, diferente das anteriores, positiva, visto que possibilita uma liberação da protagonista e não causa dano físico ou psicológico.

A mãe de Sophie também utiliza o corpo como forma de resistência, todavia, essa utilização é sempre negativa e culmina com sua morte. A primeira vez que se observa a utilização do corpo como forma de resistência por Martine é quando ela, durante sua primeira gestação, toma diversas ervas abortivas e bate diversas vezes na própria barriga como tentativa de induzir o aborto. Na segunda gestação, assim como afirmou Francis ${ }^{113}$, Tuurala ${ }^{114}$ afirma que embora o bebê tenha sido gerado com seu namorado Mark, Martine, que passou pelo trauma do estupro sem nenhum acompanhamento psicológico, acredita que o bebê que carrega no ventre é produto do estupro e que fala com ela com a voz do estuprador. Sendo assim, de modo ainda mais violento, ataca seu próprio corpo para livrar-se do bebê, esfaqueando o próprio ventre dezessete vezes, matando-o e morrendo também como consequência.

Tendo apresentado parte fundamental da fortuna crítica relativa à Breath, Eyes Memory ${ }^{115}$ que dialoga com as questões abordadas nesta tese de doutorado, passarei agora a tratar mais especificamente da análise crítica deste romance, acompanhando o processo de formação de Sophie que é permeado pelas consequências do importante e violento marco de sua origem: o estupro de sua mãe, Martine.

\footnotetext{
${ }^{113}$ FRANCIS, 2004.

${ }_{114}^{14}$ TUURALA, 2008.

${ }^{115}$ DANTICAT, 1998.
} 
Capítulo 2 Migrações Transnacionais

Sophie cresce até os doze anos no Haiti, tendo como figura materna principal sua tia Atie e contando com o carinho de sua avó Ifé. Com essa idade, é enviada aos Estados Unidos, contra sua vontade, para viver com sua mãe, que só conhecia, até então, por fotografia e pelas fitas cassetes que recebia no Haiti.

A etapa da viagem de Sophie se dá, portanto, por imposição familiar e com o intuito de restaurar um vínculo que parece tradicionalmente lógico, o vínculo biológico de mãe e filha. Há também a esperança de uma vida melhor, o que guarda semelhanças com as motivações das viagens dos outros romances aqui analisados. A mudança para Sophie é traumática, visto que Atie atuou como sua mãe até os doze anos e a mãe biológica, além de ser uma estranha, possui problemas psíquicos com os quais a menina precisará lidar.

Desde o primeiro dia de sua chegada à Nova York, Sophie observa, com estranheza, que sua mãe, uma mulher adulta, tem uma boneca da qual cuida, como filha, trançando seus cabelos, trocando suas roupas à hora de dormir, etc. Martine dedica esses cuidados à boneca, que é um objeto relacional seguro que tudo aceita e nada demanda. Na relação com a filha, entretanto, ocorre certa inversão, visto que, durante os anos em que mora com a mãe, Sophie termina por tornar-se responsável por velar o sono da mãe e despertá-la de seus pesadelos.

A exposição a um evento traumático que evoca medo intenso, desamparo ou horror e diversos outros sintomas, como frequentes rememorações ou sonhos que repetem o evento, esforço constante em evitar qualquer coisa associada ao trauma, um anestesiamento dos sentidos e apatia e, por outro lado, um estado de alerta exacerbado no que diz respeito ao que se percebe como ameaça são sintomas de Transtorno do Estresse Pós Traumático, descritos pela Associação de Psiquiatria Americana e mencionados no estudo The Psychological Consequences of Sexual Trauma, conduzido por Nicole P. Yuan et al ${ }^{116}$. As autoras também

${ }^{116}$ YUAN et al, 2011. 
explicam que crianças que sobrevivem a um trauma sexual na infância correm alto risco de desenvolver esse transtorno. Em Breath, Eyes, Memory ${ }^{117}$ esses sintomas podem ser observados nas descrições de Sophie sobre Martine, desde seu primeiro encontro, embora a menina não tenha conhecimento ou poder para alterar a realidade da mãe.

Sendo uma pessoa com transtornos psíquicos, Martine se mostra imediatamente como uma mentora falha para Sophie, uma mãe desequilibrada, autoritária e controladora. A mãe de Sophie também demonstra dificuldades em olhar para a filha, que, como reforçado em diversas situações ao longo do romance, não se parece com ninguém da família, subentendendo-se assim que a menina pareça com o estuprador, o provável Tonton Macoute que atacou sua mãe. Como Martine não havia visto o rosto de seu violador no momento do estupro, é a face da filha que permite dar um rosto ao episódio, dado que reacende o terror de Martine e aumenta seu pavor.

Concomitantemente a essa dificuldade em lidar com a filha e separar sua existência de sua origem violenta e traumática, Martine projeta, em Sophie, todos os sonhos e conquistas que não pôde realizar. Ela controla a vida da filha de tal modo que a moça, com dezoito anos, ao ser perguntada pelo namorado, Joseph, sobre o que desejava para sua vida profissional, termina por perceber que nunca havia tido liberdade para poder refletir sobre suas escolhas de vida.

Mesmo que a mãe de Sophie seja uma mentora inadequada, falha, Sophie tem, até certo momento de sua vida, mentoras amorosas e positivas, da mesma maneira que ocorre com Ponciá em Ponciá Vicêncio ${ }^{118}$ desenvolvendo-se com amor e segurança até os doze anos de idade, quando ocorre a etapa da viagem na narrativa.

Sophie vai morar com a mãe porque esta informa à Atie, por meio de uma fita cassete, que gostaria de ter a filha junto a ela. Atie considera seu desejo como algo natural e cumpre sua obrigação de irmã ao enviar a

117 DANTICAT, 1998.

${ }^{118}$ EVARISTO, 2003. 
Capítulo 2 Migrações Transnacionais

sobrinha para junto da mãe biológica, o que acredita ser melhor para a protagonista. À menina, entretanto, não é dada voz, nesse momento, e ela deixa o Haiti contra a sua vontade para ir morar com a mãe em Nova York. A viagem de Sophie ocorre como nas narrativas de formação pós-colonial anteriormente analisadas nesta tese, com o objetivo de prover uma ascensão social e econômica. No caso de Sophie, essa ascensão deverá ocorrer por meio do acesso à educação formal de qualidade e às oportunidades diversas da metrópole neocolonial americana. Isso pode ser confirmado pela expectativa de Martine de que a filha se torne médica, algo que nem ela nem Atie conseguiram alcançar.

A relação mentora/bildungsheld entre Martine e Sophie é falha, não porque Martine não deseje o bem de sua filha, mas porque após o estupro que sofre e sem ter assistência psicológica adequada, Martine não supera o trauma e não se desenvolve como um adulto mentalmente saudável e capaz de criar uma filha com equilíbrio, respeitando sua individualidade. A relação de Martine com a boneca, já mencionada, é um exemplo de como a mãe de Sophie mantém-se de certo modo presa a um estado infantil, embora ela mantenha-se funcional, sobreviva do próprio trabalho e possua um relacionamento estável com Marc, que Sophie conhece assim que chega aos Estados Unidos. A situação de Martine não é diferente da situação da maioria das mulheres que sofrem de abuso sexual na infância. Em uma pesquisa de $2003^{119}$, observou-se que mulheres abusadas sexualmente na infância mostraram-se cinco vezes mais propensas a diagnósticos de Transtorno do Estresse Pós-traumático que as demais mulheres. Além disso, verificou-se que as sobreviventes tendem a sofrer de depressão e outros problemas de saúde mental, além de serem mais propensas a tentar cometer suicídio. Um outro estudo realizado por Stratham et al ${ }^{120}$. , em 1998, demonstrou, por sua vez, explicitamente, essa relação entre o abuso sexual e o risco aumentado de suicídio. Outras consequências do trauma sexual, levantadas pelo estudo de Yuan et al., incluem o alcoolismo e os distúrbios

${ }^{119}$ COID et al. apud YUAN et al., 2011.

120 STRATHAM et al, 1998 apud YUAN et al., 2011. 
Capítulo 2 Migrações Transnacionais

alimentares, além da presença de dificuldades em certos processos de desenvolvimento, como a habilidade de desenvolver e manter relações.

A chegada de Sophie aos Estados Unidos, o encontro com uma mãe que não lhe fornece segurança, mas que na verdade tem que ser, de certo modo, cuidada por Sophie, faz com que a menina sinta ter que amadurecer de um dia para o outro. Depois da primeira noite, ao olhar-se no espelho, a menina constata: "Novos olhos pareciam olhar para mim. Todo um novo rosto. Alguém que tivesse envelhecido em um dia, como se tivesse entrado em uma máquina do tempo e não em um avião. Bem vinda à Nova York, esse rosto parecia dizer. Aceite sua nova vida." ${ }^{121}$, ${ }^{122}$. Se por um lado, Sophie precisa amadurecer rapidamente para atuar de certo modo como mãe de sua própria mãe, a falta de diálogo e orientação, o controle excessivo de Martine, prejudica seu desenvolvimento pessoal. Sophie reflete quando conhece Joseph, aos 18 anos, que desde que havia se mudado para Nova York, com 12 anos de idade, até aquele momento, sua vida havia consistido apenas em seus estudos e nos cuidados com sua mãe. Diferente de Lucy $^{123}$, que liberta-se da mãe dominadora, quando muda para os Estados Unidos, Sophie vive à sombra de sua mãe. Seu desenvolvimento, desse modo, é tolhido e o encontro com Joseph Ihe proporciona não apenas sua iniciação romântica quanto um mentor positivo. Voltarei a falar em mais detalhes dessa relação. Todavia, primeiramente, mostra-se importante, considerar o universo gótico que, assim como nos romances previamente analisados nesta tese, está presente na narrativa de Breath, Eyes, Memory.

Dos pesadelos de Martine e, mais tarde, de Sophie, ao sobrenatural nas histórias contadas por vó Ifé, Atie e Martine, do terror da entrada na escola, ao temor constante da violência sexual, elementos do Gótico permeiam a narrativa. Além disso, figuras como Erzulie da mitologia Vodu do Haiti e os próprios Tonton Macoutes, reais, mas inspirados no monstro que

\footnotetext{
121 Tradução minha.

122 "New eyes seemed to be looking back at me. A new face all together. Someone who had aged in one day, as though she had been through a time machine, rather than an airplane. Welcome to New York, this face seemed to be saying. Accept your new life." (DANTICAT, 1998, p.49).

${ }^{123}$ KINCAID, 2002.
} 
carrega um saco e mata crianças para comê-las aos poucos, aos pedaços, aprofundam a aura sobrenatural no romance e acrescentam elementos góticos à narrativa.

Tendo já comentado sobre a boneca de Martine que causa estranhamento e um certo medo em Sophie já na chegada, ressalto aqui a passagem em que Martine discorre sobre a importância de Sophie aprender a língua inglesa o mais rápido possível, informando à menina que se ela não aprendesse logo o idioma seria não apenas motivo de chacota, mas também apanharia dos alunos americanos. Além disso, Sophie é informada de como os haitianos eram vistos pelos estudantes americanos. Eles são acusados de ter "OCH - Odor Corporal Haitiano"124, ${ }^{125}$ e de terem AIDS porque os estudantes ouviram na televisão que apenas os quatro Hs (em inglês) contraíam AIDS: Hemofílicos, Homosexuais, viciados em Heroína e Haitianos.

O processo de outremização e o preconceito descritos por Martine são tomados por Sophie como aterrorizantes, e contribuem para a atmosfera de medo em que vive a protagonista. No entanto, sem enxergar saída para convencer sua mãe a não frequentar a escola, a protagonista se conforma em enfrentar a situação. Essa ambiência hostil e atemorizante é parte da interferência do gênero gótico na narrativa e consiste em uma releitura do castelo gótico. Para Sophie, a cidade de Nova York, filtrada pelo olhar de sua mãe, que é sua guardiã e mentora, impõe os mesmos temores que o castelo gótico apresentava às donzelas góticas das narrativas tradicionais do gênero do século XVIII e XIX, dentre eles o temor da violação, abdução e morte.

No que diz respeito à questão do preconceito, acrescento aqui que Breath, Eyes, Memory é o romance do corpus desta tese que trata do tema de modo mais explícito, o que se pode observar tanto no exemplo acima citado quanto na menção dos "boat people" ${ }^{\text {126 }}$, por Marc e seus amigos na

\footnotetext{
124 Tradução minha.

125 "HBO - Haitian Body Odor" (DANTICAT, 1998, p.51).

126 DANTICAT, 1998, p.54.
} 
Capítulo 2 Migrações Transnacionais

conversa no restaurante logo quando da chegada de Sophie. De acordo com um dos conhecidos de Marc, os imigrantes pobres haitianos que vinham atravessando ilegalmente de barco para os Estados Unidos é que contribuíam para a má fama dos haitianos no país e, por culpa deles, os haitianos em geral não eram respeitados.

Outros elementos do gótico presentes na narrativa podem ser observados na relação da família de Sophie com o sobrenatural e nas histórias contadas por Martine, sua avó e tia e repetidas, por vezes, por Sophie. Quando Martine realiza o teste em Sophie pela primeira vez, com a intenção de distraí-la, conta para a menina a história dos Marassas ${ }^{127}$, gêmeos divinos originários da tradição Vodu haitiana. O duplo é um elemento tradicional das narrativas góticas e os Marassas são, conforme a história contada por Martine, a cópia um do outro e por isso, amantes perfeitos.

Enquanto realiza o teste em Sophie, Martine compara a relação entre ela e a filha com a dos Marassas. A relação entre as duas, do ponto de vista de Martine, é como a dos gêmeos, amantes perfeitos. Mãe e filha seriam tão iguais que deveriam viver como um só. Essa percepção não poderia mostrar-se mais distorcida, visto que ela não permite a Sophie qualquer tipo de individualidade e, enquanto conta a história, está de fato cometendo um abuso sexual para com a filha, um ato que acarretará graves consequências psicológicas à moça.

Com o início dos testes, o distanciamento entre mãe e filha se agrava. Sophie tenta proteger-se da violência a que é submeitda por meio de um processo de dissociação. Enquanto ocorrem os testes, ela reza para a Virgem Maria, a mãe misericordiosa, e evoca lembranças positivas relativas

\footnotetext{
${ }^{127}$ De acordo com o verbete Marassa, da Encyclopedia of the African Diaspora: Origins, Experiences and Culture (BOYCE DAVIES, 2008, p.654), o termo Marassa é originário do termo kikongo Mambassa, que significa "aqueles que vem divididos". Na mitologia do Vodu haitiano, os marassas são gêmeos mais poderosos que todos os outras deidades. São considerados parte humanos e parte divinos e seu dia é o mais festejado no Vodu haitiano. Os Marassas simbolizam a ambundância, a pluralidade, a inteireza, a cura, o que é novo e a inocência, por isso eles são representados por crianças. Eles controlam as encruzilhadas e são ligados à deidade de Legba (semelhante a Exu no Brasil), que abre a porta das encruzilhadas, para a vida e para o destino.
} 
Capítulo 2 Migrações Transnacionais

ao passado com sua tia Atie, Joseph e mesmo com sua mãe. É dessa forma que ela tenta enfrentar as semanas de testes que se seguem, até o dia em que, não suportando mais, decide dar o fim aos testes.

Quando a mãe não está, resolve buscar o pistilo do almofariz, usado para pilar os temperos. Aqui se insere a história de uma mulher que, cansada de sangrar pelos poros por doze anos no Haiti e tendo buscado uma solução sem sucesso com muitos médicos, vai ao encontro de Erzulie e pede que a liberte de seu sofrimento. Erzulie ${ }^{128}$, deidade do Vodu conectada tanto à figura de mãe quanto por vezes a de uma mulher poderosa, sedutora e impiedosa, oferece à mulher transformá-la no animal de sua escolha e ela decide-se pela liberdade de uma borboleta. Sophie relembra e narra essa história enquanto vai buscar o pistilo com o qual se auto-violará, eliminando o hímen e encerrando assim os testes realizados por Martine.

Parece, desse modo, que, assim como Martine conta uma história para Sophie quando vai cometer um ato de abuso para com ela, Sophie realiza o mesmo processo em relação à si própria e ao leitor. Entretanto, do mesmo modo que a história contada por sua mãe não apaga nem ameniza a violência dos testes, a estratégia de Sophie também falha. A tentativa de desviar a atenção da própria história para a de outra mulher, uma história que é o duplo da sua, contribui para o suspense da narrativa e o terror da violação como alternativa para a libertação. A história da mulher que sofre sangrando e opta por perder sua forma original e metamorfosear-se em uma borboleta pelas mãos de Erzulie para obter liberdade é paralela a história de Sophie que "sangra", sofre, com os abusos de sua mãe e realiza sua

128 Joan Dayan (1994), em seu artigo "Erzulie: A Women's History of Haiti", descreve Erzulie como uma deusa do Vodu haitiano que representa o espírito do amor. Originária do Haiti, ela possui várias encarnações e muitas faces, carregando em si os extremos da história colonial. Erzulie pode se apresentar de três maneiras: Como Erzulie Fréda é a senhora da luxúria e do amor; como Erzulie Dantor, a mulher negra da paixão, identificada no Catolicismo com a imagem da Mater Salvatoris com o coração penetrado por uma adága; e como Erzulie-gé-rouge, a militante dos olhos vermelhos furiosa e vingativa. Dayan defende que o Vodu subverte as dualidades presentes nas religiões ocidentais, como corpo e alma, bem e mal. É preciso portanto compreender Erzulie como múltipla e complexa. Uma deusa para quem rezam muitas prostitutas, ao mesmo tempo em que tem a devoção da elite haitiana e de moças virgens. Erzulie também é importante para os homosexuais, por ser uma deusa que se relaciona tanto com homens quanto com mulheres. 
metamorfose com a auto-violação com a, intenção de libertar-se da sua vida de sofrimento e encerrar os testes.

Até certo ponto, pode-se considerar que a violência do ato de Sophie contra seu próprio corpo para livrar-se dos abusos dos testes, obteve sucesso. O uso do corpo como resistência encerra os testes, mas as consequências, tanto do abuso por parte de sua mãe quanto da violência auto-infligida, permanecerão e ela terá que enfrenta-las para quebrar o ciclo de violência perpetuado por gerações.

Sophie, depois de expulsa de casa, segue imediatamente para a casa de Joseph e aceita seu pedido de casamento. A iniciação romântica, uma etapa do Romance de Formação, conforme explicitado anteriormente nesta tese, ocorre para Sophie de maneira conturbada, tanto pela repressão da mãe quanto pelo abuso que ocasiona um trauma, e prejudica sua vida sexual com o marido. Sophie relata usar a mesma estratégia de dissociação que usava nos testes durante as relações sexuais que tem com o marido. $O$ abuso e a auto-mutilação lhe deixaram marcas físicas e psicológicas e, para tentar escapar da dor, Sophie procura dissociar a mente da experiência do corpo, visto que não consegue ter prazer durante o ato sexual.

Além disso, a moça se torna bulímica. Elaine Showalter, em The Female Malady ${ }^{129}$ discorre sobre a anorexia que se constitui como uma forma de tomar controle do próprio corpo. Essa afirmativa de Showalter ${ }^{130}$ pode ser estendida a outros distúrbios alimentares, como, no caso do romance, à Bulimia. Toda vez que tem uma relação com o marido, Sophie come todos os restos de comida que encontra na geladeira e vai ao banheiro vomitar. Para ela, o ato de ingerir a comida e poder colocá-la para fora posteriormente é a forma encontrada para reivindicar algum controle sobre seu próprio corpo, sua própria vida.

No que diz respeito à etapa do retorno às origens, constante de modo diferente no Bildungsroman tradicional e no Bildungsroman Pós-

\footnotetext{
${ }^{129}$ SHOWALTER, 1985.

${ }^{130}$ Id., 1985.
} 
colonial, em Breath, Eyes, Memory ${ }^{131}$, ela ocorre duas vezes, assim como em Ponciá Vicêncio ${ }^{132}$, sendo exemplo da variação pós-colonial, visto que não possibilita a total reinserção e reintegração da protagonista no seu ambiente de origem como ocorre, em geral, nos modelos tradicionais. Todavia, de forma diversa aos retornos de Ponciá, os dois retornos de Sophie são temporários. O primeiro se dá depois do nascimento de sua filha, quando ela desaparece de casa, sem avisar o marido e volta para o Haiti, em busca de recuperar a identidade construída pela relação amorosa com a sua avó e tia e suas raízes.

Ao ser contatada por Joseph, Martine enfrenta seus pavores e retorna ao Haiti para convencer a filha a retornar aos Estados Unidos. Aqui, pode-se inferir que Martine, que fugiu de seus temores indo para os Estados Unidos, sabe que essa fuga não trará à Sophie nenhum alívio e, sendo assim, age no interesse de mãe, demonstrando querer outro tipo de vida para sua filha. O encontro de Sophie e Martine no Haiti possibilita um enfrentamento entre a protagonista e sua abusadora. Ela pergunta diretamente à mãe porque ela a havia submetido aos testes, ao que a mãe responde: "porque foi o que minha mãe fez comigo. Não tenho uma desculpa melhor. Aqui, agora, percebo que meus maiores sofrimentos na vida são muito relacionados. A única coisa boa sobre o estupro foi que ele fez com que os testes acabassem. Os testes e o estupro, eu os vivo todos os dias."'133, 134.

Essa reflexão de Martine e o reconhecimento do erro na repetição dessa violência de controle patriarcal, se não solucionam o trauma do abuso, possibilitam, ao menos, que se reabra um canal de comunicação entre mãe e filha, além de mostrar à Sophie que ela deve procurar ajuda, se não quiser seguir o mesmo caminho da mãe. Em Ponciá Vicêncio, havia uma herança

\footnotetext{
${ }^{131}$ DANTICAT, 1998.

132 EVARISTO, 2003.

133 "'because my mother had done it to me. I have no greater excuse. I realize standing here that the two greatest pains of my life are very much related. The one good thing about my being raped was that it made the testing stop. The testing and the rape. I live both every day." (DANTICAT, 1994, p.170)

${ }^{134}$ Tradução minha.
} 
de loucura a ser passada do avô para Ponciá, uma herança inevitável, da qual ela não podia escapar. Em Breath, Eyes, Memory, a herança da violência sexual e da loucura, passa a ser vista por Sophie como algo que ela tem que lutar contra, tanto para proteger a si própria quanto para interromper o ciclo e proteger sua filha, Brigitte.

O período que Sophie passa no Haiti serve então para iniciar a reflexão no sentido da interrupção desse ciclo. Ela volta para os Estados Unidos com a mãe, inicia um tratamento psicológico em um grupo especializado em trauma sexual e retoma o contato com Martine, que a havia evitado desde sua expulsão de casa.

Enquanto a protagonista começa a traçar a superação do trauma e a quebra do ciclo de violência que poderia terminar por atingir sua filha, Martine engravida de Marc, o namorado com quem ela finge ter prazer para não ficar só e, como ela mesma explica para Sophie, para ter alguém que a acorde dos pesadelos. O estado psíquico da mãe de Sophie começa então a agravar-se. Voltando mentalmente ao período subsequente ao estupro, ela sente a presença do bebê como algo demoníaco, como se novamente estivesse gerando o fruto de um estupro, embora o filho(a) tenha sido gerado(a) de modo consensual.

Martine se mostra apavorada com a ideia de que o bebê possa parecer-se com o seu estuprador. Sophie lembra à mãe que isso não poderia acontecer, mas a mãe passa a ter alucinações, ouvindo o bebê falando com ela com a voz do estuprador, ameaçando-a e chamando-a de vagabunda. A mãe, então, informa Sophie que vai acabar com essa situação. A moça entende que Martine irá abortar, mas quando leva a questão para sua terapeuta, esta ressalta a necessidade da mãe de Sophie de se tratar, a importância de enfrentar a situação para libertar-se dela. Sem ter tempo para tomar nenhuma atitude, Sophie recebe a notícia de que sua mãe havia morrido.

Após anos lidando sozinha, sem assistência psicológica adequada, com as consequências do estresse pós-traumático acarretado pelo estupro, 
Capítulo 2 Migrações Transnacionais

Martine sucumbe e é levada por alucinações a acabar com a própria vida e com a do filho(a) ainda não nascido(a). Em uma cultura que valoriza a virgindade como a maior virtude feminina, a ponto de realizar uma violência sexual devastadora apenas para exercer o controle do corpo da mulher e que não fornece condições para o enfrentamento da violação do corpo feminino, Martine sobrevive como pode, e o quanto pode, enxergando-se como louca, culpando-se por não conseguir superar seu trauma. Ela afirma estar sempre tentando se manter um passo à frente de uma internação em uma Instituição para transtornos mentais. Também conta à filha que nunca sentiu-se feliz, e que qualquer alegria que aparentasse era apenas um fingimento para escapar da loucura.

Em sua tentativa de entender o sofrimento da mãe, Sophie explica para sua terapeuta: "Sempre foi real para ela, eu disse. São vinte e cinco anos sendo estuprada toda noite. Você poderia viver assim?"135, ${ }^{136}$. A segunda gestação de Martine ressuscita os fantasmas de seu trauma, levando-a a um caminho sem volta. Graças, entretanto, aos recursos de assistência psicológica e à orientação que recebe, Sophie tem a possibilidade de quebrar o ciclo de abuso e enfrentar seu trauma com apoio e compreensão familiar.

Responsável por providenciar o enterro de sua mãe, Sophie retorna mais uma vez ao Haiti. Esse segundo retorno também é temporário e, embora o romance termine no Haiti, infere-se que Sophie retornará aos Estados Unidos para viver como sujeito diaspórico com o marido afroamericano e sua filha. A roupa que Sophie escolhe para que sua mãe seja enterrada, um vestido vermelho, questionável para os padrões católicos, faz referência à Deusa do Vodu Haitiano, Erzulie, cujas cores fundamentais são o vermelho e o dourado. A figura de Erzulie é mencionada diversas vezes no romance, como uma deidade dupla, que por vezes é vista como maternal e comparável à virgem Maria, por vezes é a mulher selvagem e dominadora.

\footnotetext{
135 "It's always been real to her," I said. "Twenty-five years of being raped every night. Could you live with that?" (DANTICAT, 2004, P. 219)

${ }^{136}$ Tradução minha.
} 
O enterro de Martine também proporciona a Sophie um momento de catarse que certamente será um marco no seu processo de superação do trauma sexual vivido. Ao avistar o canavial, local do estupro de sua mãe, Sophie corre em sua direção e ataca violentamente a plantação, canalizando sua raiva para o evento traumático de sua origem. Sua avó impede que o padre aproxime-se de Sophie e apenas pergunta a ela: "Oú liberé?" A mesma pergunta que se faz, no Haiti, a mulheres que se livraram de um fardo muito grande e pesado, como por exemplo uma carga real de cana de açúcar. Desse modo, Sophie simbolicamente enfrenta e liberta-se do peso da história de seu nascimento e também do trauma que sofreu, podendo assim iniciar uma nova etapa de vida e oferecer um futuro de liberdade para ela e sua filha. 


\section{Conclusões}

Comparar quatro narrativas, Ponciá Vicêncio ${ }^{1}$, The Autobiography of my Mother ${ }^{2}$, Lucy ${ }^{3}$ e Breath, Eyes Memory ${ }^{4}$, que tratam do crescimento de meninas negras em sociedades periféricas, oferecendo a visão de seus percursos de forma retrospecta e por vezes fragmentada, foi um trabalho que exigiu olhar atento para aproximações e afastamentos, que demandou um posicionamento crítico constante perante a teoria disponível. Para tanto, a posição adotada por Carole Boyce Davies em Black Women, Writing and Identity. Migrations of the Subject ${ }^{5}$, de seguir uma "parte do caminho" com as teorias utilizadas, noção baseada no costume de certas tribos africanas para com seus visitantes, apresentada por Norah Zeale Hurston ${ }^{6}$, mostrou-se fundamental.

Durante toda a pesquisa procurei ter em mente que a teoria construída na Academia Eurocêntrica e Androcêntrica não poderia dar conta da experiência de cada uma dessas meninas sem ser problematizada, adaptada, trabalhada, como em uma colcha de retalhos. Foi adotando esse viés que constatei a importância da leitura da obra de Boyce Davies ${ }^{7}$ para esta tese e como sua abordagem relativa às questões teóricas e à conexão dos povos da diáspora africana constituiu de fato a espinha dorsal desta pesquisa. Entender a experiência dessas meninas/mulheres negras em suas especificidades, saber observar as conjunturas específicas, mas também os elos que as conectam à mesma experiência traumática da diáspora africana ocasionada pelo tráfico negreiro, possibilita contemplar alianças entre o povo negro diaspórico espalhado pelo mundo e facilitar uma identificação que

\footnotetext{
${ }^{1}$ EVARISTO, 2003.

${ }^{2}$ KINCAID, 1997.

${ }^{3}$ KINCAID, 2002.

${ }^{4}$ DANTICAT, 1998.

${ }^{5}$ BOYCE DAVIES, 1994.

${ }^{6}$ HURSTON, Norah Zeale, 1979 (in WALKER, Alice, 1979) apud BOYCE DAVIES, 1994.

${ }^{7}$ BOYCE DAVIES, op. cit.
} 
traga força maior e apoio para suas lutas em cada país que o recebeu na diáspora.

A teoria polissistêmica de Itamar Even-Zohar também se mostrou extremamente útil para entender as interferências nas narrativas de gêneros como o Bildungsroman e o Gótico Inglês do século XVIII. O Bildungsroman, gênero originalmente usado pelos poderes coloniais, é subvertido em uma variável pós-colonial e consiste no arcabouço que compõe a base de todas as narrativas estudadas na tese. Relembro aqui o exemplo do piano citado por Vázquez ${ }^{8}$, instrumento originalmente utilizado para a expressão da música clássica que teve seu uso alterado e subvertido para abarcar e transmitir experiências musicais diversas como o Blues, o Rock e, aqui incluo também, o Chorinho e a Bossa Nova, experiências conectadas com o Novo Mundo, as Américas e a força do povo africano na diáspora. Da mesma maneira, o Bildungsroman tradicional é transformado e tem suas etapas alteradas para expressar a experiência das sociedades pós-coloniais, no caso das narrativas em foco, das experiências do crescer de meninas negras em sociedades periféricas, pós-coloniais, patriarcais. Essa transformação acarreta a criação de uma variante do Bildungsroman que é a do Bildungsroman Pós-Colonial, como descrita por Vázquez ${ }^{9}$. Seguindo uma parte do caminho com Vázquez ${ }^{10}$, que realizou a análise de romances póscoloniais escritos por homens e com protagonistas masculinos para a sua definição de Bildungsroman Pós-Colonial, observei nos romances em foco nesta tese, as etapas da separação, iniciação, escolha e retorno, mantendo em mente as novas possibilidades, bem como as divergências, acarretadas nessas etapas, em romances de escritoras negras que tratam da formação de protagonistas femininas negras.

A teoria polissistêmica possibilita entender a apropriação do Bildungsroman tradicional, tanto pelos escritores quanto pelas escritoras pós-coloniais, e a subversão desse gênero pela interferência das experiências de sujeitos marginais, no caso, meninas negras de ex-colônias

\footnotetext{
${ }^{8}$ VÁZQUEZ, 2003.

${ }^{9}$ Id., 2003

${ }^{10} \mathrm{Id} ., 2003$.
} 
que vivem sob dominação patriarcal. O Romance de Formação Pós-colonial é que torna possível a narração da experiência das protagonistas no seu tornar-se mulher e de seus processos de desenvolvimento, de migração e movimento, que certamente não poderiam encaixar-se nas narrativas tradicionais do gênero. Sem essas interferências, elas permaneceriam inenarráveis, indizíveis.

O gênero Gótico também atravessa os séculos, a partir de seu sistema literário original, inglês e do século XVIII, interferindo nessas narrativas publicadas no fim do século $X X$ e início do século $X X I$. As convenções góticas apropriadas pelas narrativas analisadas nesta tese possibilitam expressar justamente o indizível da experiência do colonizado, o terror inominável ligado ao trauma da escravidão, dos rompimentos forçados com as origens e a dificuldade de reconstituir uma identidade destroçada pela outremização, seja ela para o estabelecimento de um sistema escravocrata, seja ela para manter uma posição subalterna no póscolonialismo ou no sistema patriarcal. O gênero se mostra de fato indispensável para narrar as vivências das protagonistas nas sociedades patriarcais pós-coloniais e periféricas de que são originárias.

Elementos como o sobrenatural, a violência sexual, a metamorfose, o duplo, entre outros, são encontrados nos quatro romances desta tese e usados para transmitir os temores inerentes ao tornar-se mulheres, ao viver como imigrantes, sujeitos diaspóricos, sempre outros, e, por vezes, marginais, sujeitos que buscam, em meio a um mundo opressor e aterrorizante, conciliar suas identidades.

A questão identitária nos romances analisados também se mostra extremamente significativa. O tráfico negreiro acarreta uma quebra na conexão com a ancestralidade, com as raízes, e uma conexão forçada justamente com o opressor. Essa conexão se impõe da maneira mais perversa, que é por meio da nomeação. Duas das protagonistas dos romances têm como sobrenome o nome do senhor de escravos: Ponciá Vicêncio e Lucy Josephine Potter. É nessas duas narrativas que se percebe portanto a maior rejeição identitária. Ponciá chega ao ponto de preferir ser 
chamada de "Nada" a ser chamada pelo próprio nome com o qual não se identifica. Lucy mostra-se sempre consciente da origem perversa do nome que a identifica, um nome que vem daqueles que escravizaram os seus antepassados. Para essas duas protagonistas, os primeiros nomes também são uma questão: Para Ponciá, o acento em seu nome é como um chicote a açoitá-la. Ponciá não é um nome africano, não a conecta com suas origens, assim como Vicêncio, é, na narrativa, prova de uma violência contra seu povo. Lucy também não se identifica com seu prenome até questionar sua mãe quanto a ele. Embora chocada com a resposta da mãe, a associação do nome Lucy a Lucífer é libertadora, para ela, e facilita a compreensão de sua relação com a mãe, para Lucy, um ser divino e terrível. Sendo ela filha deste ser, ela se sente então livre para ser como Lucífer, um anjo caído.

Em The Autobiography of my Mother ${ }^{11}$, Xuela Claudette Richardson também questiona seu nome. Ela sabe que leva o nome da mãe, mas sabe também que esse nome lhe havia sido dado por uma freira que recebera sua mãe, ainda bebê, depois de ter sido abandonada na porta do convento. $O$ sobrenome Richardson veio de um homem branco, seu avô paterno, que abandona a família, levando as primeiras economias de seu pai. Xuela, ao contrário de seu pai que durante todo o romance apega-se ao sobrenome e ao branqueamento como forma de ascensão, nega essa identidade branca e procura sempre identificar-se com o mais oprimido, no caso do romance, com os índios Caribe, ligados à origem de sua mãe.

Em Breath, Eyes, Memory ${ }^{12}$, o sobrenome de Sophie, Caco, embora conectado ao nome dos grupos de camponeses que resistiram à ocupação americana, mostra-se problemático pelo fato de ser fato conhecido que os homens desses grupos atacavam sexualmente as mulheres camponesas que lutavam a seu lado. Além disso, o sobrenome de Sophie só vem do lado de sua mãe, visto que o nascimento dela é resultado de um estupro. Aqui, a identidade da protagonista também é ligada à violência e à história colonial,

\footnotetext{
${ }^{11}$ KINCAID, 1998.

12 DANTICAT, 1998.
} 
no entanto a violência sexual é mais explicitada que na origem das outras protagonistas.

À questão do nome, alia-se uma marca de inferioridade imposta a essas meninas pela estrutura social das sociedades pós-coloniais e patriarcais em que nasceram, um impedimento de atingir seu potencial como seres humanos pelo simples fato de serem sujeitos periféricos, mulheres e negras. A elas são reservados os destinos de empregadas domésticas, como para Ponciá, de enfermeiras, como o sonhado para Lucy por sua mãe ou de professora, como deseja o pai de Xuela. Embora as duas últimas profissões sejam vistas em uma posição hierárquica mais elevada que a de empregada doméstica, ainda é possível observar nelas o domínio patriarcal, posto que são profissões tradicionalmente femininas que demandam o cuidar do outro. Além disso, não são nunca escolhidas pelas protagonistas, Ponciá é empregada porque é o que lhe sobra, o que lhe é possível, e as profissões de enfermeira e professora são impostas à Lucy e Xuela por seus pais, imposição que ambas recusam. Quanto à Sophie, a expectativa, de certo modo, é inversa. Sua mãe quer que a filha seja médica, mas isso é também uma imposição que não considera a subjetividade de Sophie.

Ponciá, Xuela, Lucy e Sophie crescem todas em um ambiente que não permite o desenvolvimento de sua subjetividade, um ambiente opressor com o qual não se identificam. A representação dessas meninas em seu crescer tem em comum a expressão de um sentimento de não pertencer que, de fato, é o motor de impulsão do movimento do não pertencimento em todas as narrativas analisadas nesta tese. Esse movimento consiste na busca das protagonistas por espaços próprios, físicos e simbólicos. Provoca rompimentos familiares, abandonos do lar, migrações domésticas e transnacionais, além de profundas mudanças internas, as viagens in situ.

Esse movimento do não pertencimento, termo cunhado por mim na presente tese, a partir da observação da experiência das protagonistas aqui analisadas, é que impele a etapa da separação do Bildungsroman Póscolonial, observada em momentos diversos em cada um dos romances. A 
Conclusões

separação em Ponciá Vicêncio ${ }^{13}$ ocorre porque Vila Vicêncio oferece à Ponciá o mesmo destino de seus antepassados, o trabalho na roça, a exploração, a impossibilidade de progresso. Lucy parte para os Estados Unidos para libertar-se das limitações impostas tanto na ilha caribenha em que vive quanto na relação opressora com sua mãe, repetidora do sistema patriarcal. Para Xuela, a separação primeira, a morte de sua mãe, e a falta de amor do seu pai e da sociedade pós-colonial da ilha de Dominica, a impelem a uma movimentação e separações constantes. Enfrentando a falta do amor, resistindo e lutando contra ela, Xuela impõe suas regras e define os rumos de sua vida. Em uma viagem mística, quando toma as ervas abortivas, percorre toda a ilha de Dominica e reivindica para si a terra que sempre pertenceu a parte de seus antepassados, os Caribes, os aniquilados, e para onde outra parte foi trazida forçadamente, os subjugados escravos negros. Essa experiência de caminhar sobre a terra e reivindicar sua posse é um momento de consolidação identitária para Xuela. A partir desse movimento, ela passa a saber quem é e, do não pertencimento, passa ao pertencimento. Já no caso de Sophie, a primeira separação é imposta para que ela se reencontre com a mãe e prospere social e economicamente, mas é a segunda separação, o afastamento dessa mãe, desequilibrada e abusadora, que possibilita que ela se liberte e torne-se uma mulher adulta.

A segunda etapa do Romance de Formação Pós-colonial, a iniciação romântica/sexual, ocorre nas narrativas, de modo geral, de maneira incompleta, insatisfatória, quando não, violenta. Ponciá envolve-se afetivamente com o pedreiro que vem a tornar-se seu companheiro, mas não consegue abrir para ele mais que seu "corpo-pernas"14. Embrutecidos pela vida dura que levam e a perda de sete filhos, não há entre eles comunicação e Ponciá torna-se vítima de violência doméstica. Sophie é a personagem de que se pode afirmar ter tido uma iniciação romântica e não apenas sexual. Ela de fato apaixona-se por Joseph, mas a herança do controle patriarcal representado e exercido por sua mãe, macula a experiência com o abuso

\footnotetext{
${ }^{13}$ EVARISTO, 2003.

${ }^{14}$ Ibid., p.43.
} 
sexual dos testes e sua auto-violação para livrar-se deles. Depois de violarse com o pistilo do almofariz, Sophie casa-se com Joseph, mas a dor física e a culpa a impedem de ter prazer nas relações sexuais com o marido. Tanto Lucy quanto Xuela, personagens de Kincaid $^{15}$ reivindicam seu corpo como arma de imposição de sua subjetividade. Elas definem como, onde e até quando em todas as suas relações afetivas/sexuais. Nessas relações, no entanto, essas personagens parecem estar sempre na defensiva, como se a relação de afeto contivesse implicitamente a relação da dominação colonial.

Outro elemento importante do romance de formação que precisa ser adaptado na variante pós-colonial é a atuação do mentor e sua relação com a protagonista. O mentor prioriza a defesa da ordem estabelecida em detrimento do bem estar do herói/heroína, podendo mesmo explorá-lo. Os mentores pós-coloniais são em geral falhos, visto que sua função de orientar o bildungsheld é incompatível com o papel tradicional de guardião da ordem social.

Essa ordem mostra-se extremamente repressora e carece de legitimidade aos olhos do sujeito pós-colonial, especialmente quando este sujeito é uma mulher negra. Ponciá e Sophie possuem mentoras positivas durante a infância, Ponciá conta com sua mãe e Nêngua Kainda em Vila Vicêncio, enquanto Sophie vive rodeada de carinho com sua tia Atie e avó Ifê. Os missionários que vão à Vila Vicêncio e as patroas com quem Ponciá trabalha são os mentores falhos com que ela tem que lidar no seu processo de tornar-se mulher. Os missionários chegam com muitas promessas, mas ensinam as crianças a ler as primeiras palavras e depois as abandonam. Das patroas, pode se inferir que, embora tenham passado alguns conhecimentos práticos dos afazeres domésticos, não ofereceram nenhuma possibilidade de desenvolvimento outro para Ponciá como o faz o Soldado Nestor para o irmão dela. Com respeito à Sophie, quando ela chega à Nova York, é recebida pela mãe, traumatizada pelo estupro, ainda sofrendo de possível transtorno pós-traumático. Sophie logo constata que não pode contar com a mãe como mentora e é por isso que já no dia seguinte a sua

\footnotetext{
${ }^{15}$ KINCAID, 2002. KINCAID, 1997.
} 
chegada sente que ao olhar-se no espelho outros olhos a miravam de volta, olhos cansados e envelhecidos, olhos que já haviam entendido que ela precisaria rapidamente amadurecer para cuidar da mãe e sobreviver. E ela o faz, da melhor maneira possível, porém a falta de orientação, de espaço para sua subjetividade e o autoritarismo de sua mãe deixam graves lacunas psicológicas na sua formação. Lacunas que ela vai ter que preencher no futuro para viver uma vida adulta.

A primeira mentora de Lucy é sua mãe. Em princípio, a relação entre Lucy e ela é uma relação percebida pela protagonista como uma relação de muito amor, mas isso muda quando sua mãe tem o primeiro filho homem. Nesse momento, Lucy é relegada ao papel secundário destinado às mulheres nas sociedades patriarcais e os olhares de admiração e sonhos de conquistas de sua mãe são destinados todos para os filhos homens que ela tem em seguida. É a partir daí que Lucy apelida sua mãe de senhora Judas. Enxergando a traição de sua mãe a ela, uma aliança com o patriarcado que repete a opressão da mulher, a menina decide planejar sua partida.

A segunda mentora de Lucy, funciona, de fato, como uma mentora às avessas. Mariah, a dona de casa americana, serve de contraponto às reflexões de Lucy quanto ao processo de colonização e exploração que sofreu o povo negro diaspórico, quanto às relações raciais e a posição dos Estados Unidos como potência neocolonial dominadora. A relação entre a protagonista e Mariah proporciona, de todo modo, uma possibilidade de desenvolvimento subjetivo, tanto para uma quanto para outra, e o processo por que passa Mariah é comparável a um despertar, como em uma Novel of Awakening. Peggy também pode ser vista como uma mentora da protagonista, que the fornece as ferramentas para viver como uma mulher adulta na cidade de Nova York. Observa-se a simultaneidade da influência dessas novas mentoras junto à forte presença da mãe de Lucy, mesmo fisicamente ausente, em toda a narrativa. Com relação à sua mãe, mesmo constatando a impossibilidade de livrar-se totalmente de sua influência, a protagonista decide cortar todos os vínculos com ela e permanecer nos Estados Unidos. Essa atitude é a forma que Lucy encontra para tentar 
conciliar suas identidades fragmentadas e enfrentar a vida como uma mulher adulta.

Xuela, tendo perdido sua mãe ao nascer, e sendo levada recémnascida pelo pai para que fosse cuidada pela lavadeira de suas roupas. Identifica um mundo sem amor na ilha pós-colonial de Dominica, uma impossibilidade de amar em uma ilha em que a população foi ensinada a desconfiar uns dos outros, a acatar o discurso de outremização do colonizador que desvaloriza a ela própria. Reconhecendo a aridez e a falta de amor que a rodeia, a opressão que permeia a sociedade pós-colonial e patriarcal em que vive, Xuela recusa todo mentor ou mentora que the aparece. Ela não aceita Ma Eunice porque, embora reconheça anos depois seus esforços, não acha que a mulher embrutecida pela vida fosse capaz de amar. Despreza a professora, que ao mesmo tempo que discrimina Xuela, classificando a como pertencente aos aniquilados caribes, é uma mulher que se odeia por ser negra, acatando o papel de derrotada que o processo colonial de outremização the impôs. A madrasta que poderia ser uma possível mentora demonstra imediatamente seu medo de que Xuela ocupe seu espaço e seu desejo de aniquilar a menina. Com ela, Xuela precisa estabelecer mesmo uma estratégia de resistência e sobrevivência.

O pai de Xuela e Mme LaBatte também são recusados como mentores. Em seu pai, Xuela observa não só a falta de amor, mas o apego ao dinheiro e a crueldade para com o próximo, principalmente os mais destituídos. Ela também percebe o desejo de aceitação e poder que seu pai sente, a máscara branca que ele veste durante toda a vida. Afastando-se do pai, procura se identificar sempre com o grupo em menor vantagem, reivindicando por fim a sua identidade caribe, a identidade dos aniquilados. Mme LaBatte é a única pessoa com quem Xuela se relaciona de modo mais próximo, mas Mme LaBatte quer obter algo de Xuela, o filho que a mulher, mais velha, não pode gerar. A protagonista não aceita qualquer tipo de dominação e, sendo assim, também se afasta dela. Em determinado momento, Xuela reconhece as limitações de ser ela sempre sua própria mentora, mas prossegue assim durante toda a narrativa. Sua opção, visto 
que não acredita na capacidade de amor no mundo pós-colonial e que perde, ao nascer, a única pessoa que acredita poder provar-lhe o contrário, é uma opção pela liberdade. Se não há amor, que pelo menos haja liberdade e que seja ela, sempre, a pessoa a determinar os rumos de sua vida. Assim ela o faz, assim conduz seu caminhar.

As etapas da escolha e do retorno nos romances ocorrem também em acordo com a variante do romance de formação pós-colonial. Em Ponciá, não há escolha de fato, visto que a decisão de retornar para Vila Vicêncio é tomada pela sua família. Encontrada na rodoviária pelo irmão, andando de um lado para o outro e fazendo esculturas no ar, ela é levada para a roça. Não há um fechamento e, embora a intenção da família seja proteger Ponciá, não se sabe o que irá lhe acontecer. Há a possibilidade de que a proximidade com os seus e com o barro funcione de modo terapêutico e viabilize um resgate da identidade da protagonista, mas é impossível saber se Ponciá realmente se recuperará da depressão e fragilidade psíquica a que chegou.

Lucy opta por não retornar ao Caribe e também por cortar todo contato com sua mãe, essa decisão é importante para que ela possa buscar a independência da presença opressora de sua mãe e das regras sociais da sociedade pós-colonial e patriarcal da ilha de onde veio. Regras que, seguidas, impediriam que ela pudesse viver como sujeito pleno, em suas aspirações e contradições. A página em branco ao final do romance é símbolo das novas possibilidades, da autonomia e do poder de Lucy para escrever sua própria história como sujeito diaspórico e migrante.

Sophie, por sua vez, realiza dois retornos ao Haiti. No primeiro, ela busca o acolhimento de sua terra natal e da avó e tia que são suas mentoras positivas e referencias de afeto. Ela vai para o Haiti sem pensar em voltar, mas sua mãe conversa com ela e a filha retorna para os Estados Unidos. Após a morte de Martine, é Sophie quem toma as providências do enterro e retorna assim uma segunda vez ao Haiti. Esse segundo retorno, claramente provisório, é o que possibilita que Sophie enfrente seus demônios e temores e em um ato simbólico, em que ela desfecha golpes contra o canavial onde 
sua mãe havia sido estuprada, a moça finalmente consegue sentir o fardo dessa experiência ser retirado. "Oú liberé?"16 é a pergunta que faz sua avó, a mesma pergunta que se faz para mulheres que carregam um fardo pesado no Haiti. Em The Autobiography of my Mother ${ }^{17}$, por sua vez, Xuela passa toda a narrativa movimentando-se de um lugar para outro da ilha de Dominica e enfrentando também profundas modificações internas. No fim do romance, muda-se para as terras dos caribes com o marido de origem inglesa e ,depois da morte dele, decide permanecer nessa região até o fim de seus dias.

Os romances Ponciá Vicêncio ${ }^{18}$, The Autobiography of my Mother ${ }^{19}$, Lucy $^{20}$ e Breath, Eyes Memory ${ }^{21}$ e o processo de crescimento de suas protagonistas, analisados nesta tese de doutorado, demonstram as conexões entre as experiências das meninas/mulheres negras que crescem na diáspora africana. O trauma da escravidão, a importância dada à acenstralidade e às conexões com as origens extremamente dificultadas pelo tráfico negreiro e a opressão que cortou os laços com a terra de origem, com os antepassados e impôs uma identificação perversa dos negros diaspóricos com os senhores de escravos, perpetuando essa dominação por séculos e séculos, são questões em comum enfrentadas pelas protagonistas nas sociedades periféricas e pós-coloniais em que vivem. Além disso, o sistema patriarcal dessas sociedades que opera para limitar a subjetividade dessas mulheres e limitar suas conquistas também se faz sentir no crescer de cada uma dessas protagonistas.

Observando comparativamente a representação dessas meninas/mulheres negras em romances de autoras do Brasil, Haiti e Antigua, autoras que, como as personagens também passaram por processos de migração, seja interna ou transnacional, concluo que, de fato,

\footnotetext{
${ }^{16}$ DANTICAT, 1998, p.234.

${ }^{17}$ KINCAID, 2002.

${ }^{18}$ EVARISTO, 2003.

${ }^{19}$ KINCAID, 2002.

${ }^{20}$ KINCAID, 1997.

${ }^{21}$ DANTICAT, 1998.
} 
como afirmou Michael Hanchard ${ }^{22}$, a diáspora é um colar de contas humano e o fio de sua conexão é o tráfico negreiro, um fio que atravessa as Américas sem se importar com as fronteiras nacionais. Não há como modificar essa origem criminosa da presença dos negros em tantos países fora da África, mas este estudo deixa sua contribuição para confirmar a ideia de Carole Boyce Davies ${ }^{23}$ de que é possível sim contestar a noção do negro como minoria. É possível conectar as experiências de mulheres negras de países periféricos, patriarcais e pós-coloniais, de modo que elas saibam que não são poucas e não estão sós.

Com a análise dessas narrativas de formação pós-coloniais, dos movimentos realizados pelas protagonistas em suas aproximações, como as motivações econômicas, a busca de espaços menos opressivos, as tentativas de determinação de seus próprios destinos ou em seus afastamentos relacionados com as diversas conjunturas geográficas, econômicas, sociais culturais e mesmo pessoais, também deixo minha contribuição para que se entenda a experiência da mulher negra, não apenas como aquela determinada pela literatura afro-americana ou o feminismo negro americano que, como ressaltado nesta tese, embora tenham trazido importantes contribuições terminaram por estabelecer uma certa hierarquia no que diz respeito ao que significa a experiência da mulher negra, estabelecendo a mulher negra americana como paradigma da experiência da mulher negra no mundo.

Não analisei as trajetórias das protagonistas como alegorias nacionais, mas como personagens únicas, cujas experiências semelhantes são conectadas a aspectos históricos e conjunturas socioeconômicas em comum, como a origem de seus antepassados pela diáspora africana ocasionada pela escravidão, a vida em sociedades periféricas e póscoloniais e a opressão sofrida por elas em um sistema patriarcal. As reações e as possibilidades alcançadas por cada uma delas mantém, no entanto, especificidades que dizem respeito ao histórico familiar e pessoal de cada

${ }^{22}$ HANCHARD, Michael, 1990 apud BOYCE DAVIES, 1994.
${ }^{23}$ BOYCE DAVIES, 1994. 
uma, sendo assim mantém-se a diversidade de representação das mulheres negras na literatura diaspórica para a qual esta tese contribui.

O movimento tornou-se, de fato, questão central na análise aqui realizada e importante elemento comum às narrativas da tese, desde o movimento inicial dos antepassados das protagonistas, pela diáspora africana do período escravocrata, até o movimento do não pertencimento, por mim definido nesta tese. Esse movimento, com seus deslocamentos físicos (migrações domésticas e transnacionais) e suas movimentações internas, suas jornadas in situ, com as buscas das protagonistas por uma construção identitária que Ihes possibilite um lugar confortável no mundo, um lugar físico e simbólico para sua subjetividade, um sentir-se bem em sua própria pele, um pertencimento, é comum a todas as protagonistas.

O sentimento de não pertencimento impulsiona o movimento constante do não pertencimento tanto nos deslocamentos domésticos, de Ponciá Vicêncio ${ }^{24}$ e Xuela ${ }^{25}$, quanto nas migrações transnacionais, de Lucy ${ }^{26}$ e Sophie $\mathrm{Caco}^{27}$. O movimento do não pertencimento também é o instrumento de buscas pelo espaço próprio, físico e simbólico, realizado pelas protagonistas. Essas buscas, por vezes, acarretam rompimentos familiares temporários, como os que ocorrem com Ponciá e Sophie Caco, ou permanentes, como para Lucy, que rompe qualquer contato com a mãe e o país de onde veio. O rompimento de Xuela, entretanto, é o que mais bem demonstra que o movimento de distanciamento pode ocorrer, mesmo que a proximidade física se mantenha. Ela se distancia afetivamente muito cedo de seu pai e, em seguida, de seus parentes, mesmo tendo convivido muito tempo com eles na ilha de Dominica.

O movimento do não pertencimento, conforme observei na análise dos romances desta tese, pode também gerar jornadas in situ que consistem em retornos às experiências da infância e mesmo a um passado histórico que inclui a escravidão, a opressão dos antepassados, a supressão das

\footnotetext{
${ }^{24}$ EVARISTO, 2003.

${ }^{25}$ KINCAID, 1997.

${ }^{26}$ KINCAID, 2002.

${ }^{27}$ DANTICAT, 1998.
} 
raízes e a imposição de uma identificação com o opressor, através do que é mais individual, o sobrenome.

Essas jornadas exigem das protagonistas um esforço de conciliação de seu passado histórico e de suas identidades fragmentadas e ocorrem, com maior ou menor sucesso, nos quatro romances. Ponciá Vicêncio, vítima de uma sociedade patriarcal e de contrastes econômicos e sociais extremos, enlouquece e tem sua chance de reencontrar-se e definir-se como sujeito no retorno imposto pela família à comunidade rural em que cresceu. Xuela toma as rédeas do seu destino e, embora reconheça, ao fim da vida, que a existência sem amor pela qual optou é uma existência limitada, é ela quem demonstra, entre todas as narrativas, mais agência, maior controle de suas decisões. Ao terminar seus dias nas terras dos índios caribes, seus antepassados por parte de mãe, e reivindicar a posse da ilha de Dominica na viagem mística que realiza, quando do aborto a que se submete com o uso de ervas, ela encontra seu lugar. Lucy, como Ponciá, não chega ao final do romance com nada definido, mas rompe com a mãe e o país de origem e tem a sua frente a página em branco em que poderá conciliar ou administrar suas identidades fragmentadas. Com respeito a Breath, Eyes, Memory, não se pode dizer que, ao final, Sophie Caco esteja curada do trauma do abuso sexual a que foi submetida, mas a volta ao Haiti para enterrar a mãe e o episódio de liberação de seus sentimentos de raiva e mágoa contra 0 canavial em que sua mãe fora estuprada é um passo fundamental para seu movimento em direção a uma vida emocionalmente mais saudável com seu marido e filha nos Estados Unidos.

O movimento do não pertencimento observado nas narrativas não traz soluções mágicas para o trauma ancestral da escravidão que conecta as protagonistas dos romances, nem apaga as estruturas patriarcais a que foram submetidas e pelas quais foram oprimidas no seu crescer, mas como a própria Lucy afirma: "Às vezes, não há como escapar, mas com frequência o esforço da tentativa serve muito bem por um tempo." ${ }^{28}, 29$.

\footnotetext{
${ }^{28}$ Tradução minha.

29 "Sometimes, there is no escape, but often the effort of trying will do quite nicely for a while". (KINCAID, 2002, pp.36,37).
} 
O movimento do não pertencimento consiste, portanto, nessa tentativa de buscar novas construções identitárias que se articulem de modo mais positivo para essas mulheres negras, de encontrar novos espaços para que suas subjetividades possam ser plenamente desempenhadas, ultrapassando as limitações determinadas pelas sociedades patriarcais, periféricas e pós-coloniais de que são originárias. Narrativas como as de Ponciá, Xuela, Lucy e Sophie Caco tornam possível enxergar possibilidades diversas para as mulheres negras na diáspora, possibilidades independentes do paradigma da mulher negra americana, possibilidades que apontam ao mesmo tempo para a aproximação de seus contextos sócio-históricos, mas também para as especificidades de suas individualidades, de suas buscas e trajetórias.

Concluo esta tese, minha contribuição para o fortalecimento do colar de contas da diáspora africana, estreitando as conexões referentes à experiência das mulheres negras na literatura e promovendo o entendimento de que aquilo que, muitas vezes, é categorizado como minoria, em cada país, ao ganhar visibilidade, pode ser entendido de forma diversa. Quando se extrapolam as fronteiras geopolíticas e se consideram as experiências comuns dos vários povos da diáspora, através de aproximações e alianças, se estabelece um processo de empoderamento que pode provocar inúmeras modificações no tecido social. Expresso aqui também o desejo de que as teorias com que caminhei, os conceitos costurados e articulados e a análise das obras desta tese possam contribuir para novos estudos que continuem a ampliar e aprofundar a compreensão da experiência das meninas/mulheres negras no contexto da diáspora africana. 


\section{Referências}

\section{OBRAS DO CORPUS DE ANÁLISE}

DANTICAT, Edwidge. Breath, Eyes, Memory. New York: Vintage Contemporaries, 2 ed, 1998.

EVARISTO, Conceição. Ponciá Vicêncio. Belo Horizonte: Mazza Edições, 2 ed, 2003.

KINCAID, Jamaica, Lucy. New York: Farrar Straus Giroux, 2002.

The autobiography of my mother. New York: Plume/Penguin, 1997.

\section{OUTRAS OBRAS DE FICÇÃO DAS AUTORAS DO CORPUS} York, 2004.

DANTICAT, Edwidge. Behind the Mountains. Scholastic Inc. New Brother, l'm dying, Vintage Contemporaries - Vintage Books, The Dew Breaker, Vintage Contemporaries - Vintage Books, New York, 2004.

EVARISTO, Conceição. Becos da Memória, Belo Horizonte: Mazza Edições, 2006. 1997.

KINCAID, Jamaica, Annie John. New York: Farrar Straus Giroux, 1984. At the bottom of the River. New York: Farrar Straus Giroux, My Brother. New York: Farrar Straus Giroux, 1998. A Small Place. New York: Plume/Penguin Books, 1989. 


\section{OBRAS TEÓRICAS}

ABRAHAM, Keshia N. The Caribbean Woman Writer as a Scholar: Creating, Imagining, Theorizing. Coconut Creek, Florida: Caribbean Studies Press, 2009.

ALVES, Elis Regina Fernandes. Outremização e revide de colonizado e colonizador em The Narrative of Jacobus Coetzee (1974), de J.M. Coetzee, 2006. Dissertação (Mestrado), Universidade Estadual de Maringá, $\quad$ Paraná, $2006 . \quad$ Disponível em: http://www.ple.uem.br/defesas/pdf/erfalves.pdf Acesso em: 24 de abril de 2013

ANZALDÚA, Gloria. "Voz narrativa en Breath Eyes, Memory de Edwidge Danticat", MEMORIAS: Revista digital de Historia y Arqueologia desde el Caribe colombiano, Ano 7, nr 13, Barranquilla, 2010, ISSN 17948886 .

ARAÚJO, Flávia Santos de, UMA ESCRITA EM DUPLA FACE: A MULHER NEGRA EM PONCIÁ VICÊNCIO, DE CONCEIÇÃO EVARISTO, 2007. Dissertação (Mestrado), UEPB/CCHLA, João Pessoa, Paraíba, 2007. Disponível em: <http://www.cchla.ufpb.br/ppgl/images/Flavia.pdf>. Acesso em: 14 de julho 2014.

ARRUDA, Aline Alves, Ponciá Vicêncio, de Conceição Evaristo: um Bildungsroman feminino e negro. Literafro, Universidade Federal de Minas Gerais, Belo Horizonte, 2007.2 Disponível em: <http://www.letras.ufmg.br/literafro/data1/autores/43/conceicaocritica02.pdf> Acesso em: 14 de julho 2014.

A errância diaspórica como paródia da procura em Ponciá Vicêncio, de Conceição Evaristo e um Defeito de Cor, de Ana Maria Gonçalves. Anais do XII Seminário Nacional Mulher e Literatura e do III Seminário Internacional Mulher e Literatura - Gênero, Identidade e Hibridismo Cultural, outubro de 2007, Universidade Estadual de Santa Cruz, Ilhéus/Bahia. Disponível em: <http://www.uesc.br/seminariomulher/anais/PDF/ALINE\%20ALVES\%20ARR UDA.pdf>. Acesso em: 14 de julho de 2014.

ASHCROFT, B. et al. Key Concepts in Post-Colonial Studies. London: Routledge, 1998.

BHABHA, Homi K. O local da Cultura. Belo Horizonte: Editora UFMG, 2010.

BELCHIOR N, "Menino negro é espancado e amarrado nu em poste na Zona Sul do Rio", Afroativismo na Rede: Liberdade e direitos humanos, 
Referências

Carta

Capital.

Disponível

em:

$<$ http://negrobelchior.cartacapital.com.br/2014/02/04/menino-negro-e-

espancado-e-amarrado-nu-em-poste-na-zona-sul-do-rio/>. Acesso em: 07 de agosto de 2014.

BESSON, Gérard. Folklore and Legends of Trinidad and Tobago. Port of Spain, Trinidad and Tobago, Paria Publishing Company Limited, 2a edição,1994.

BONNICI, Thomas. Resistência e intervenção nas literaturas póscoloniais. Maringá: EDUEM - Editora da Universidade Estadual de Maringá, 2009.

BOUSON, J. Brooks. Jamaica Kincaid. Writing Memory, Writing Back to the Mother. Albany: State University of New York Press, 2005.

BRAZIEL, Jana Evans, Caribbean Genesis: Jamaica Kincaid and the Writing of New Worlds. Albany, New York: SUNY Press, 2009.

CHEN, Kuan-hsing. MORLEY, David. Stuart Hall, Critical dialogues in Cultural Studies. New York: Routledge, 1996.

CHOW, Rey et SUGG, Katherine, "I would rather be dead": Nostalgia and Narrative in Jamaica Kincaid's "Lucy", Narrative, vol. 10 nr. 2 (May, 2002), pp. 156-173, Ohio State University Press. Acessado em: http://jstor.org/stable/20107282 em 10/02/2013.

CLITANDRE, Nadége. "Reframing Haitian Literature Transnationally: Identifying New and Revised Tropes of Haitian Identity in Edwidge Danticat's Breath, Eyes, Memory", Journal of Haitian Studies, Vol 9, nr 2 (Fall, 2003), pp. 90-110. Center for Black Studies Research, 2003. http://www.jstor.org/stable/41715221. Acessado em 18 de abril de 2015.

COUNIHAN, Clare. Desiring Diaspora: "Testing" the Boundaries of National Identity in Edwidge Danticat's Breath, Eyes, Memory. Small Axe, Volume 16, Nr 1, pp. 36-52. Durham, North Carolina: Duke University Press, 2012.

CUDJOE, Selwyn R. Caribbean Women Writers: Essays from the first International Conference. Wellesley, Massachusetts: 1990.

DAVIES, Carole Boyce. Black Women Writing and Identity Migrations of the Subject. London: Routledge, 1994.

Moving Beyond Boundaries, Volume 2: Black Women's Diasporas. New York: New York University Press, 1995.

OGUNDIPE-LESLIE, Molara. Moving Beyond Boundaries, Volume 1: International Dimensions of Black Women's Writing. New York: New York University Press, 1995. 
. Caribbean Spaces, Escapes from Twilight Zones. Urbana, Chicago and Springfield: University of Illinois Press, 2013.

.FIDO, Elaine Savory. (Orgs.) Out of the Kumbla - Caribbean Women and Literature. Trenton, NJ: Africa World Press, 1990.

. MAZRUI, ALI A. OKPEWHO, Isidore. AFRICAN DIASPORA, AFRICAN ORIGINS AND NEW WORLD IDENTITIES. Bloomington and Indianapolis: Indiana University Press, 2001. and Culture, ABC - clio, Santa Barbara - CA, USA, 2008.

Encyclopedia of the African Diaspora: Origins, Experiences

DAYAN, Joan. "A Women's History of Haiti", Research in African Literatures, vol. 25, nr. 2, Special Issue: Caribbean Literature (Summer, 1994), $\quad$ p. 5-31, Indiana University Press, http://www.jstor.org/stable/4618262 Acessado em 08 de agosto de 2015.

DIAS, Ângela Maria. Longe do Paraíso: Jazz, de Toni Morrison e Ponciá Vicêncio, de Conceição Evaristo. Estudos de Literatura Brasileira Contemporânea, Nr 32. Brasília: Universidade de Brasília, 2008. ISSN 2316.4018. $<$ http://seer.bce.unb.br/index.php/estudos/article/view/2006>. Acesso em: 08 de agosto de 2014.

DIAS, Mileide Santos; DIAS, Manuela Santos. Ponciá Vicêncio e a Busca da Identidade. Anais do Seminário Internacional Acolhendo as Línguas Africanas - SIALA, 29 a 31 de agosto de 2012, Salvador - BA. Disponível em: $<$ http://www.siala.uneb.br/pdfs/2012/mileide_santos_dias1.pdf>. Acesso em: 12 de agosto de 2014.

DONALDSON, E. Laura; PUI-LAN, Kwok (eds.). Post-Colonialism, Feminism and Religious Discourse. New York: Routledge, 2002.

DUARTE, Eduardo de Assis, LITERATURA E AFRODESCENDÊNCIA NO BRASIL: antologia crítica - Consolidação, volume 2, Belo Horizonte: Editora UFMG, 2011.

. LITERATURA E AFRODESCENDÊNCIA NO BRASIL: antologia crítica - História, teoria, polêmica, volume 4, Belo Horizonte: Editora UFMG, 2011.

O Bildungsroman afro-brasileiro de Conceição Evaristo, Revista Estudos Feministas (online), vol.14, n.1, pp. 305-308. ISSN 0104026X, 2006. Disponivel em: $<$ http://www.scielo.br/pdf/ref/v14n1/a17v14n1.pdf>. Acesso em 14 de julho de 2014. 

Picador, 2012.

DUBOIS, Laurent. Haiti: The Aftershocks of History. New York:

DUTTON, Wendy. Merge and Separate: Jamaica Kincaid's Fiction. World Literature Today, Vol. 63, No 3 (Summer, 1989), pp. 406-410. http://www.jstor.org/stable/40145312. Acessado em 07/02/2013.

EVEN-ZOHAR, Itamar. Poetics Today, Vol. 11, No. 1, Polysystem Studies, Durham, North Carolina: Duke University Press Stable. Disponível em: <http://www.jstor.org/stable/1772666>. Acesso em: 26 de junho de 2009. Press, 2007.

FANON, Frantz. BLACK SKIN, WHITE MASKS. New York: Grove 2004. THE WRETCHED OF THE EARTH, New York: Grove Press,

FERREIRA, Elio; MENDES, Algemira de Macedo (Orgs). Literatura afrodescendente: memória e construção de identidades. São Paulo: Quilombhoje, 2011.

FIGUEIREDO, Eurídice. Conceitos de literatura e cultura. Juiz de Fora: Editora UFJF/EdUFF, 2005.

FLEENOR, Juliann (ed.). The Female Gothic. Montreal: Eden Press, 1983.

FRANCIS, Donette A. "Silences too horrific to disturb": Writing sexual histories in Edwidge's Danticat's Breath, Eyes, Memory", Research in African Literatures, Vol 35, Nr 2, Summer 2004, pp 77-90. Indiana University Press, 2004.

GADSBY, Meredith M. Sucking Salt: Caribbean Women Writers, Migration, and Survival. Columbia, Missouri: University of Missouri Press, 2006.

HALL, Stuart. A identidade cultural na pós-modernidade. Rio de Janeiro: DP\&A editora, 1998.

Sovik. Belo Horizonte: Editora UFMG, 2003.

Da diáspora: Identidades e Mediações Culturais. Org. Liv

HARRYS, Leila Assumpção, "A PRODUÇÃO LITERÁRIA DE ESCRITORAS CONTEMPORÂNEAS QUE MIGRARAM DO CARIBE PARA O CANADÁ E OS ESTADOS UNIDOS". In: GOMES, André Luís; STEVENS, Cristina.(Orgs). Revista Cerrados, n.32, ano 20, Universidade de Brasília, 2011. 
HERNANDEZ, Jennifer Browdy de. Women Writing Resistance, Essays on Latin America and the Caribbean. Cambridge, Massachusetts: South End Press, 2005.

HEWITT, Heather. Mothering across Borders: Narratives of Immigrant Mothers in the United States. In: Women's Stud Q 37 no 3/4 Fall/Wint 2009, p.121-39. New York: Feminist Press at the City University of New York, 2009.

HOLANDA, Heloísa Buarque de. Tendências e impasses - O feminismo como crítica da cultura. Rio de Janeiro: Rocco, 1994.

HULL, Gloria T.; SCOTT, Patricia Bell; SMITH, Barbara. All the Women are White, All the Men are Black, but Some of Us are Brave. Black Women's Studies. New York: The Feminist Press at The City University of New York, 1982.

KORNFELD, Eve et JACKSON, Susan. "The Female Bildungsroman in Nineteenth-Century America: Parameters of a Vision." Journal of American Culture. Vol. 10 Iss. 4, 1987.

LAGUARDIA, Adelaine. MEMÓRIA, TRAUMA E CONFISSÃO EM WHY THE CAGED BIRD SINGS, DE MAYA ANGELOU, Anais do XIV Seminário Nacional Mulher e Literatura / V Seminário Internacional Mulher e Literatura, Universidade de Brasília, 2012.

LAHNI, Cláudia Regina et al (Orgs.). Cultura e diásporas africanas. Juiz de Fora: Editora UFJF, 2009.

LANG-PERALTA, Linda. Jamaica Kincaid and Caribbean Double Crossings. Newark. University of Delaware Press. 2010.

LIMA, Maria Helena. Decololnizing Genre: Jamaica Kincaid and the Bildungsroman, GENRE XXVI - WINTER, 1993, p.431-459. The University of Oklahoma.

MACHADO, Bárbara Araújo. Caminhos Editoriais na trajetória intelectual de Conceição Evaristo. Anais do XXVII Simpósio Nacional de História: Conhecimento Histórico e Diálogo Social. ANPUH, Natal, RN, 22 a 26 de julho de 2013. Disponível em: <http://www.snh2013.anpuh.org/resources/anais/27/1364347958_ARQUIVO _TrabalhoAnpuh.pdf>. Acesso em: 11 de agosto de 2014.

MARDOROSSIAN, CARINE M. "From Literarure of Exile to Migrant Literature", Modern Language Studies, vol 32, Nr 2 (Autumn, 2002), pp. 1533. Modern Language Studies. http://jstor.org.stable/3252040. Acessado em 02 de fevereiro de 2013. 
MARTIN, Tony. Caribbean History: From Pre-Colonial Origins to the Present. New York: Pearson, 2012.

MELLEM, Laura. The (Nation) State of Family: Remembering the links between collective rape and the cult of virginity in in Edwidge's Danticat's Breath, Eyes, Memory, Caribbean Women Writers Independent $\begin{array}{llll}\text { Study, } & \text { Dr. } & \text { Supriya } & \text { Nair, }\end{array}$ http://stonecenter.tulane.edu/uploads/Mellem,_Laura_Tulane_Nair_WebVersi on-1418421700.pdf Acessado em 08 de julho de 2015.

MIGNOLO, Walter. Histórias Locais / Projetos Globais. Colonialidade, Saberes Subalternos e Pensamento Liminar. Belo Horizonte: Editora UFMG, 2003.

MOHAMMED, Patricia. Gendered Realities: Essays in Caribbean Feminist Thought. Kingston, Jamaica: University of the West Indies Press, 2002.

MONTEIRO, Maria Conceição; LIMA, Tereza Marques de Oliveira (Orgs.). Entre o estético e o político: A mulher nas literaturas de línguas estrangeiras. Santa Catarina: Editora Mulheres, 2006.

NEGRO JR., Paulo Jacomo, PALLADINO-NEGRO, Paula, LOUZÃ, Mário Rodrigues. "Dissociação e Transtornos Dissociativos: Modelos Teóricos" Revista Brasileira de Psiquiatria, Vol. 21, nr 4, São Paulo, dezembro, $1999 . \quad$ Disponível em: http://www.scielo.br/scielo.php?script=sci_arttext\&pid=S151644461999000400014 Acesso em: 20 de maio de 2015.

NICHOLS, Jennifer J., "Poor Visitor": Mobility as/of Voice in Jamaica Kincaid's Lucy. MELUS, Volume 34, Number 4 (Winter 2009), Oxford University Press.

OGOT, Bethwell Allan. História Geral da África: África do século XVI ao XVIII. Volume V. Brasília: Unesco, 2010.

PAULA, A. M. N. R.; JÚNIOR, J.C. , MIGRAÇÕES INTERNAS NO SERTÃO DAS GERAIS: "A ESPERANÇA DE MELHORIA DE VIDA", UNIMONTES CIENTÍFICA, Montes Claros, v.4, n.2, jul./dez., $2002 . \quad$ Em http://www.ruc.unimontes.br/index.php/unicientifica/article/viewFile/65/62 (acessado em 30 de junho de 2014)

PARAVISINI-GEBERT, Lizabeth. "Colonial and Post Colonial Gothic: The Caribbean". in HOGLE, Jerrold E., The Cambridge Companion to Gothic Fiction. Cambridge. Cambridge University Press. 5a edição. 2007. 
Referências

PIERCE, Yolanda. "Restless Spirits: Syncretic Religion in Edwidge's Danticat's Breath, Eyes, Memory". The Journal of Pan African Studies, vol. 3, $\mathrm{nr}$ 5, March, 2010 http://www.jpanafrican.com/docs/vol3no5/3.56newRestless.pdf Acessado em 12 de julho de 2015

PRATT, Annis. "Woman and Nature in Modern Fiction." Contemporary Literature. Vol. 13, n. 4, Autumn 1974. University Press, 1981.

Archetipal Patterns in Women's Fiction. Bloomington: Indiana

ROJO, Antonio Benítez. La Isla que se Repite. El Caribe y la Perspectiva Posmoderna. Ediciones del Norte, 1989.

RUTHVEN, K. K. Feminist Literary Studies: An Introduction. UK: Cambridge University Press, 1984.

SAID, Edward W. Orientalismo - O Oriente como invenção do Ocidente. São Paulo: Companhia das Letras, 2007.

SANTOS, Lorena. "Queda e Ascensão em Desonra de J. M. Coetzee". Revista Cerrados, vol 18, $\mathrm{n}^{\circ}$ 27, Universidade de Brasília (UnB), 2009. ISSN 1982- 9701

SHOWALTER, Elaine. A Literature of Their Own: British Women Novelists from Brontë to Lessing. Princeton: Princeton University Press, 1997.

The Female Malady - Women, Madness and English Culture, 1830 - 1980. Penguin Books, New York, USA, 1985.

SILVA, Denise Almeida. Espaço, memória e agência em Ponciá Vicêncio. ANTARES Letras e Humanidades, vol. 3, nº 6, Jul./Dez. 2011.

SPIVAK, Gayatri Chakravorty. Pode o subalterno falar? Belo Horizonte: Editora UFMG, 2010.

STEVENS, Cristina et VASCONCELOS Vânia. Mães de Outras Cores: Matrifocalidade na Literatura Afro-Brasileira." In: GOMES, André Luís; STEVENS, Cristina (Orgs.). Revista Cerrados, vol 20, n 32, ano 20, Brasília: Universidade de Brasília, 2011. ISSN 1982- 9701

SHEPHERD, Verene A. RICHARDS, Glen L. Questioning Creole, Creolisation Discourses in Caribbean Culture. Kingston, Jamaica: Ian Randle Publishers, 2002.

THOMSON, D. H. A Glossary of Literary Gothic Terms. Literature and Philosophy Department, Georgia Southern University, 2007. Disponível 
em: $\quad$ <http://saylor.org/site/wp-content/uploads/2012/05/engl403-1.3.1-AGlossary-of-Literary-Gothic-Terms.pdf>. Acessado em setembro de 2015.

THIONG'O, Ngugi Wa (Organizador). Decolonising The Mind. The Politics of Lbutianguage in African Literature. Translation Journal, 1986.

TODOROV, Tzvetan. The Fantastic, A Structural Approach to a Literary Genre. New York: CORNELL UNIVERSITY PRESS, 1975

VARMA, P. Devendra. The Gothic Flame. Being a History of the GOTHIC NOVEL in England. Its Origins, Efflorescence, Disintegration, and Residuary Influences. New York: Russell \& Russell, 1966.

TUURALA, Hanna-Tuulia. Struggle for Independence: Postcolonialism Reflected in the Problematic Parent-Child Relationships in the Works of Jamaica Kincaid and Edwidge Danticat, Dissertação de Mestrado. University of Tampere School of Modern Languages and Translation Studies (2008). Disponível em: https://tampub.uta.fi/bitstream/handle/10024/79935/gradu02968.pdf?sequenc e=1 Acessado em 08 de julho de 2015.

UNESCO. Mapa e área da Commonwealth of Dominica. Disponível em: http://www.unesco.org/csi/smis/siv/Caribbean/Dominica.htm. Acesso em $13 / 03 / 2015$.

VALENTE, Marcela lochem. A tradução e a construção de imagens culturais: Ponciá Vicêncio, de Conceição Evaristo, e sua tradução para o inglês. Tese de Doutorado, Rio de Janeiro: Pontifícia Universidade Católica do Rio de Janeiro (PUC-Rio), 2013.

VARMA, Devendra P. The Gothic Flame. RUSSEL \& RUSSEL. New York, 1966.

VÁZQUEZ, José Santiago Fernández. Reescrituras postcoloniales del Bildungsroman, Editorial Verbum, Madrid, 2003.

WEINHARDT, Marilene; CARDOZO, Maurício Mendonça (Orgs.). Centro, Centros - Literatura e Literatura comparada em Discussão. Curitiba: Editora UFPR, 2011.

YOUNG, M. Iris. La Justicia y la Política de la Diferencia. Tradução de Silvina Álvarez. Madrid: Ediciones Cátedra, Universitat de València, Instituto de la Mujer, 2000.

YUAN, Nicole P. et al. The Psychological Consequences of Sexual Trauma. National Resource Center on Domestic Violence, 2011. Harrisburg, 
PA, USA, $\quad$ http://www.vawnet.org/applied-research-papers/printdocument.php?doc id=349 Acessado em 28/05/2014. 